\title{
Domestic Factors and Episodes of Gross Capital Inflows
}

Rogelio Mercado Jr.

TEP Working Paper No. 1916

December 2016

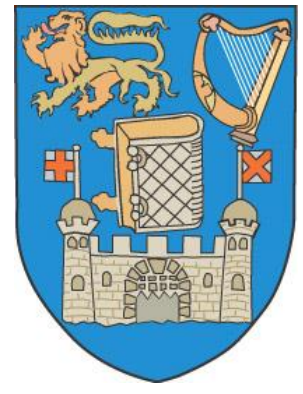

Trinity Economics Papers

Department of Economics

Trinity College Dublin 


\title{
Domestic Factors and Episodes of Gross Capital Inflows
}

\author{
Rogelio Mercado Jr.* \\ Northumbria University
}

December 2016

\begin{abstract}
This paper extends the literature on gross capital flows by looking into domestic factors that covary significantly with cross-country differences in the transitional likelihoods of moving between episodes of capital inflows. Applying a state-transition framework, we view states of gross capital inflows as "normal", "surge", and "stop", following Forbes and Warnock (2012a and 2012b) approach in identifying extreme episodes for a sample of 55 advanced and emerging economies from 1980Q1 to 2014Q4. The empirical findings show that cross-country differences in transitional likelihoods are strongly associated with state-dependence variables such as duration and occurrence. There is evidence to suggest the presence of negative duration dependence on the transitional likelihood of moving between episodes such that the longer an economy spends in a given episode, the less likely it will exit that episode. However, duration and occurrence of episodes of gross capital inflows are also significantly correlated with domestic factors such as output volatility, de facto and de jure financial openness, and foreign reserves.
\end{abstract}

Keywords: capital flows, surges, stops, capital flows transitions

JEL codes: F30, F32, F36

\footnotetext{
*Lecturer in Economics, Newcastle Business School, Northumbria University, Email: rogelio.mercado@northumbria.ac.uk

The author is highly indebted to Philip R. Lane for his valuable comments and suggestions. The author is also grateful to Agustin Benetrix, Vahagn Galstyan, Hiro Ito, and Frank Warnock for their comments and suggestions on this paper.
} 


\section{Introduction}

The onset of financial liberalization that started in the 1980s has sparked waves of cross-border capital flows, bringing in costs and benefits to both advanced and emerging economies. Among the benefits are risk-sharing, efficient allocation of financial resources, and adherence to best practices. But financial globalization also comes at a price. As cross-border financial flows increased, countries have become more vulnerable to extreme episodes of financial flows due to domestic, global and contagion factors. In fact, both the global financial crisis of 2008-09 and emerging market crises in the early 1980s and mid-1990s illustrate how economies can transition from receiving huge foreign capital to a sudden and severe reversal of foreign capital inflows. However, the experiences of countries are varied. Given adverse changes in global factors, some countries experience more reversals of foreign capital flows alongside deep recessions while others do not. Conversely, given positive developments in global factors, some countries receive more foreign capital "bonanzas" or "surges" while others do not. It is then important to look into cross-country differences in their likelihood of transitioning between episodes of capital inflows.

Capital flows have been studied at various dimensions, including their impact on growth, relevant drivers, policy tools in addressing their adverse effects, and the nature of capital flows. ${ }^{1}$ On more specific area of research, several papers draw attention to the determinants and effects of extreme episodes of capital flows. ${ }^{2}$ For instance, literature on "sudden stops" shows that when global factors deteriorate, economies face painful adjustments, exchange rate depreciation, bankruptcies, and economic contractions. At the other extreme, literature on "surges" indicates that capital inflows are related to asset price inflation, currency appreciation, commodity price booms, and higher probability of experiencing "stops" especially in emerging economies.

However, these studies do not discuss differences in the likelihood of countries in transitioning from one episode to another. We note two reasons on the importance of this research. First, recent papers highlight the strong correlation between global factors, such as global risk aversion, with the occurrence of extreme episodes of capital flows. ${ }^{3}$ In contrast, some papers argue that although global factors drive capital flows, whether a country actually experiences an extreme episode ultimately depends on its domestic factors. ${ }^{4}$ This paper supports the latter view by bringing back domestic factors at the centre but from a different angle. Instead of focusing on what factors determine the occurrence of extreme episodes, we look into which factors relate to cross-country covariation in transitional likelihoods of moving between episodes of gross capital inflows. Specifically, we look at the covariation between transitional likelihoods and state-dependence variables; and the covariation between state-dependence variables and domestic factors. This topic has not been fully explored in the literature.

Second, knowing which domestic factors relate to cross-country differences in transitional likelihoods imply a country's vulnerability or fragility in experiencing extreme episodes. For instance, one stylized fact presented in this paper shows that advanced economies tend to have, on average, higher transitional likelihood of moving from "normal" to an extreme episode. Knowing which factors covary with cross-country differences in transitional likelihoods suggest cross-country propensity in experiencing extreme episodes.

\footnotetext{
${ }^{1}$ See Koepke (2015) for a survey of literature on capital flows; Ostry et al. (2010) on capital controls; Kaminsky et al. (2005) and Bluedorn (2013) on nature of capital flows including size, composition, cyclicality and volatility.

2 Throughout this paper, we follow the naming convention of Forbes and Warnock (2012a and 2012b) in calling "stops", "surges", "flights" and "retrenchments" as "extreme" episodes of gross capital flows. However, we only focus on "stops" and "surges" which relates to gross capital inflows.

${ }^{3}$ See Forbes and Warnock (2012a), Fratzscher (2012), and Milesi-Ferretti and Tille (2011).

${ }^{4}$ This conjecture was first emphasized by Calvo et al. (2006) for systemic sudden stops, and later on by Ghosh et al. (2014) on surges.
} 
This paper sets out three tasks. First, it identifies extreme episodes, namely "stops" and "surges", following the approach of Forbes and Warnock (2012a and 2012b) using quarterly data on gross capital inflows for 55 advanced and emerging economies from 1980Q1 to 2014Q4. Second, it computes fixed transitional likelihood and provides stylized facts on cross-country variation. ${ }^{5}$ Third, it considers state-dependence variables (duration and occurrence) in the context of capital flow episodes. Lastly, it looks at the correlations between transitional likelihoods of moving between episodes, state-dependence variables and domestic factors. Four questions are considered. First, are there differences in transitional likelihoods across countries such that do some countries have higher or lower transitional likelihood than others? Second, what factors significantly covary with the transitional likelihoods of moving between episodes? Third, which domestic factors covary with state-dependence variables? Lastly, do we see any difference between debt and equity inflows?

In order to address the key questions in this paper, we step back from the literature on capital flows and look into state-transition framework used in labour economics and business cycle literature. ${ }^{6}$ In labour economics, we find employment transition models where individuals move between different states of employment like from employment to unemployment. In the business cycle literature, economies move between contractions and expansions. We can then view "normal", "surge", and "stop" episodes of gross capital inflows as different states and derive their fixed transitional likelihood of moving from one state to another. Next, we see from the labour economics literature the relevance of individual characteristics for the transitional probabilities of moving between employment states. We consider the same for episodes of capital flows where individual characteristics now pertain to domestic factors. Similar to transition studies of employment, we consider the role of state-dependence variables (duration and occurrence) in the transition process. Intuitively, we are abstracting from global factors which are common across countries, and assess which factors significantly covary with transitional likelihood.

Our computed transitional likelihoods reveal that the likelihood of moving from normal episode to either extreme episode is low, but the likelihood of staying in an extreme episode is relatively high. In addition, we also note cross-country differences in transitional likelihood such that some countries have higher transitional likelihood while others have lower. To know which domestic factors are relevant for transitional likelihood, we first regress transitional likelihood on statedependence variables to know how strongly these variables covary. Next, we estimate statedependence variables on domestic factors to establish the extent of how strong domestic factors covary with state dependence variables, which in turn correlate with transitional likelihood.

The results reveal a strong link between the transitional likelihoods and the state-dependence variables (duration and occurrence). We find evidence of negative duration dependence such that a country that experiences an episode longer will most likely remain in that episode and less likely move to another episode. We also find evidence that state-dependence variables are significantly correlated with domestic factors such as output volatility, de facto and de jure financial openness, and foreign reserves for episodes of total gross inflows. We note that domestic factors can operate either through one or both state-dependence variables. For instance, higher foreign reserves are strongly correlated with longer duration of normal episodes of total gross inflows; but significantly correlated with more frequent occurrence of debt and equity stop episodes. In contrast, for equity inflows, financial openness is significant for both duration and occurrence. These findings indicate

\footnotetext{
${ }^{5}$ We use "likelihood" instead of "probability" as we do not specify a specific probability function.

${ }^{6}$ See Ballen and Freeman (1986), Blau (1998), Bradley et al. (2003), Heckman and Borjas (1980), Lynch (1989), Martinez-Granado (2002), on labour transitions literature; and Diebold and Rudebusch (1990), Filardo (1994), and Filardo and Gordon (1998) on business cycle transitions.
} 
strong cross-country covariation between transitional likelihoods and state-dependence variables. In turn, state-dependence variables significantly covary with domestic factors. ${ }^{7}$

This study makes several contributions to the literature on capital flows. First, using state-transition framework, we are able to know and draw cross-country stylized facts on the likelihood of transitioning from various episodes of gross capital inflows. Second, by focusing on fixed transitional likelihood, we are able to abstract from factors common across countries and then assess which domestic factors correlate with the propensity of experiencing various capital flow episodes. Third, unlike in the labour literature, this paper looks at the factors that covary with state-dependence variables.

This paper is structured as follows. Section 2 provides conceptual framework on capital flows and the application of state-transition framework for episodes of gross capital inflows. Section 3 provides the empirical specification. Section 4 discusses data source and stylized facts. Section 5 discusses empirical analysis and sensitivity tests; while Section 6 concludes.

\section{Conceptual Framework}

\subsection{Capital Flows "Push" and "Pull" Framework}

A key area of research on capital flows pertains to its determinants. In this area, the overarching theme is what factors matter most for capital flows. These factors are broadly categorized as "push" factors which are external to an economy, such as global or contagion factors, and domestic "pull" factors that pertain to domestic macroeconomic fundamentals. The prevailing consensus in the literature points to the relevance of both factors. For instance, Calvo et al. (1993 and 1996) and Fernandez-Arias (1996) find global factors, such as interest rates related to business cycles in advanced economies, matter more than domestic factors. In contrast, Chuhan et al. (1998) argue more for domestic factors like domestic returns. But most studies found the relevance of both factors not only for the size but also for the volatilities of total and components of capital flows. ${ }^{8}$

A narrower branch of literature on capital flows looks at the "push" and "pull" factors in the context of unusually large foreign capital inflows or outflows, known as either "surges" or "stops" which are broadly grouped as extreme episodes. Understanding the determinants and consequences of these extreme episodes in the context of global and domestic factors has become important in the literature as they have significant policy implications. For example, if global factors are more relevant during episodes of large foreign capital outflows than domestic factors, then it implies that policy makers have little influence over such huge foreign outflows. The same goes for large foreign capital inflows. But if domestic factors are more pertinent, then domestic policy makers have more control over the adverse consequences of stops and surges.

On the causes and effects of extreme episodes, the early literature on "stops" is motivated by the crises experience of emerging economies in the 1990s, including Mexico in 1994, Asian economies in 1997-98, and Russia in 1998, as these economies experienced sharp withdrawal of foreign capital inflows. Calvo (1998), Calvo et al. (2006), and Calvo et al. (2008) argue that "stops" occur through balance-sheet effects, where any deterioration in global factors triggers large real exchange rate depreciation which increases the burden of debt payment of countries with large foreign currency denominated debt liabilities. These authors argue that "sudden stops" have detrimental

\footnotetext{
${ }^{7}$ However, given our small sample size, we find few domestic factors significant and, in most cases, they are marginally significant. Nonetheless, the results hold under several sensitivity tests.

${ }^{8}$ See Koepke (2015) for a comprehensive review on the literature of capital flows under the push and pull framework.
} 
consequences as firms face insolvencies and bankruptcies, caused by disruptions of credit that lowers capital productivity leading to output loss.

In contrast, studies on "surges" or "bonanzas" came earlier than those on "stops". This was motivated by the increase in capital flows to emerging Latin America economies in the early 1990s, following domestic policy reforms and the implementation of debt relief programs. Calvo et al. (1993 and 1996) trace the factors driving "surges" as well as their impact on the domestic economy. They find that huge foreign capital inflows, when triggered by global factors such as low global interest rates, increase private consumption and domestic investment which, in turn, raise the price of nontradable goods, leading to real exchange rate appreciation. Their study highlights the impact of "surges" on the rapid growth of monetary base through sterilization and reserve accumulation.

In later literature, Caballero (2014), Magud et al. (2014), and Reinhart and Reinhart (2009) look at the relation between "surges" and domestic credit expansions. They argue that high foreign capital inflows improve financial conditions and increase domestic bank credit. However, as domestic credit expands through foreign lending, the probability of banking crises rises because of greater risktaking which exacerbates problems of asymmetric information and moral hazard. Sula (2010) investigates the direct link between "surges" and "stops". He finds that "surges" increases the probability of experiencing "stops" especially if foreign inflows are channelled to private loans.

On the empirical tests of drivers of extreme episodes, existing studies looked into global, domestic, and contagion factors. The findings indicate that the high occurrence of "stops" relates to lower domestic growth, more financially open economies, large dollarization of domestic liabilities, dependence on commodity exports, low global growth, high global risk aversion, foreign-driven, huge banking inflows, large exchange rate depreciation, and contagion effects. In contrast, economies more open to trade are less vulnerable to "stops" as foreign investors associate trade openness with lower probability of debt default, while those with more stable economies also experience less "stops". 9

For "surges", low global interest rates that make debt payment and access to international funding easier, low global risk aversion, and business cycle expansions in advanced economies are the relevant global factors. Policy reforms, trade and financial openness, sound macroeconomic policy, growth shocks, external financing needs, and exchange rate regime are the significant domestic factors. In addition, contagion factor is also significant. ${ }^{10}$

Most of these studies use pooled dataset with several countries and periods in testing the relevance of global, domestic, and contagion factors in the occurrence of extreme episodes. ${ }^{11}$ The key question addressed by this approach is what factors lead to the occurrence of extreme episodes across economies through time. Most of these studies use pooled probit regression where the dependent variable is a binary variable taking the value of 1 if the period corresponds to an extreme episode. This method has several advantages and implications for the results. First, such method offers substantial data points for consistent and robust estimation. Second, it allows factors to vary across time. This has important implications for the results as both domestic and global factors do change over time, more so when they are cyclical in nature, such as global growth, global risk aversion, and

\footnotetext{
${ }^{9}$ Refer to the studies of Calderon and Kubota (2013), Calvo et al. (2008), Cavallo and Frankel (2008), Forbes and Warnock (2012a), Levchenko and Mauro (2007), Milesi-Ferretti and Tille (2011), and Rothenberg and Warnock (2011).

${ }^{10}$ See the papers of Caballero (2014), Calvo et al. (1993 and 1996), Forbes and Warnock (2012a and 2012b), Ghosh et al. (2014), Magud et al. (2014), and Reinhart and Reinhart (2009).

${ }^{11}$ See Calderon and Kubota (2013), Calvo et al. (2008), Cavallo and Frankel (2008), Forbes and Warnock (2012a and 2012b), Ghosh et al. (2014), and Sula (2010).
} 
domestic shocks. ${ }^{12}$ Under this approach, one could directly establish that an increase in global risk aversion, for example, is significantly correlated with a higher occurrence of "stops" as shown by Forbes and Warnock (2012a and 2012b) and Milesi-Ferretti and Tille (2011).

Few studies have used time-series approach in looking at the evolution or pattern of key macroeconomic variables around periods of extreme episodes. The relevant question under this setup is how domestic factors behave around extreme episodes. An example would be Reinhart and Reinhart (2009), where they study the behaviour of current account, real GDP growth, inflation, and real exchange rate before, during, and after "surges". They find a distinct V-shaped pattern for current account as it deteriorates into the "surge" year and then improves steadily after. Domestic growth rises into the "surge" but then slows and settles back into the pre-surge growth rate. Similarly, Broner et al. (2013) looks into the pattern of capital inflows and their components around crises periods and find that capital inflows tend to be higher in the pre-crisis period and then collapse during and after crises.

The literature has not yet dealt with cross-country variation in experiencing extreme episodes. Considering cross-sectional set-up allows us to identify factors that are important in explaining crosscountry differences or factors that are relevant in explaining cross-country heterogeneity in the occurrence of capital inflow episodes. It is this type of query that this paper addresses.

\subsection{State-Transition Framework}

The lack of empirical studies dealing with sources of cross-country differences in transitional likelihood of moving between episodes of capital flows can be addressed by looking into different fields of economics such as labour economics and business cycle theory. Both fields have applied a Markovian state-transition framework in their respective fields. The labour economics literature uses state-transition framework in analysing individual transitions between various employment states. The business cycle literature also applies the Markovian framework in assessing transitions between economic expansions and contractions.

The labour economics literature offers considerable insights into transitions between employment states. $^{13}$ Several key themes are noted. First, transitions between states depend on observed individual characteristics such as the level of education, age, ethnicity, among others. ${ }^{14}$ Second, the empirical approaches in estimating the determinants of transitions between states are broadly classified into two. One pertains to the use of fixed transitional probabilities as the dependent variable such as those employed by Ballen and Freeman (1986), while others use a pooled probit approach including Blau (1998), Bradley et al. (2003), Lynch (1989) and Martinez-Granado (2002). Under the latter approach, overall labour market conditions are included in the regression specification; but not in the former. The key distinction is that the former looks at the sources of variation of individual's transitional probabilities, while the latter focuses on factors that relate to an individual's transitions from one state to another. Third, to account for past employment history, state-dependence variables are considered in the empirical specification. Of importance is the presence of positive or negative duration dependence.

Accounting for state-dependence variables has been crucial in the application of the Markovian state transition framework in labour economics. A critique of the state-transition framework is how to

\footnotetext{
12 Some studies consider structural domestic factors in their pooled dataset. For instance, Forbes and Warnock (2012a and 2012b) included per capita income and financial system; while Ghosh et al. (2014) considered exchange rate regime, capital account openness, and quality of institutions. These are, in fact, structural in nature as they change slowly over time.

${ }^{13}$ Refer to the studies of Ballen and Freeman (1986), Blau (1998), Bradley et al. (2003), Lynch (1989) and Martinez-Granado (2002).

${ }^{14}$ Unobserved individual attributes correlated with the transitions are controlled for in their empirical approach. For instance, Heckman and Borjas (1980) use differences in duration or length between two employment and unemployment spells.
} 
account for past experiences. Heckman and Borjas (1980) develop theoretical foundations to account for state-dependence in the labour economics. They differentiate different types of statedependence, including: (i) occurrence dependence which suggests that as the number of previous unemployment spells increases, the probability that a worker will become or remain unemployed increases since employers use employment records in their hiring and firing decisions; (ii) duration dependence proposes that the probability of remaining unemployed depends on the length of time the worker has been unemployed in his current unemployment spell; and (iii) lagged duration dependence which suggests that the probabilities of remaining unemployed or becoming unemployed depends on the length of previous unemployment spells due to loss of productivityenhancing work experience.

Among the abovementioned state-dependence variables, duration dependence matters most for transitions between employment states. Positive duration dependence implies that the longer one spends in a given state, the more likely one will exit that state; while negative duration dependence suggests that the longer one spends in a given state, the less likely one will exit that state. The test for negative duration dependence is then crucial since if one is unemployed, the more likely one will remain unemployed. In contrast, if positive duration dependence exists, then an unemployment spell will most likely be followed by an employment spell. Blau (1998) and Lynch (1989) confirmed the significance of negative duration dependence in the labour market transitions.

Following Heckman and Borjas (1980), we show the relation between transitional likelihoods and state-dependence variables. Transitional probabilities stem from hazard functions in state-transition literature. Hazard functions are defined as the conditional density of exit time from a given state based on time spent in the state in the current spell. For a Weibull exponential time distribution, Heckman and Borjas (1980) proposed a general model which combines duration, occurrence, and lagged duration dependence for a hazard function, given by

$$
h_{x y}^{(l)}\left(t_{x y}^{(l)}\right)=g_{x y}^{(l)}\left(t_{x y}^{(l)}, \ldots, t_{x y}^{(1)}, t_{y x}^{(l)}, \ldots, t_{y x}^{(1)}\right),
$$

where $t$ is time, $x$ and $y$ are two different states, and $I$ are spells. If $\partial h_{x y}\left(t_{x y}\right) / \partial t_{x y}>0$, then we have positive duration dependence. This means that if one spends more time in a given state, the more likely one will exit that state. If $\partial h_{x y}\left(t_{x y}\right) / \partial t_{x y}<0$, then we have negative duration dependence, which implies that the longer one stays in a given state, the less likely it will exit that state. If $\partial h_{x y}\left(t_{x y}\right) / \partial t_{x y}=0$, then there is no duration dependence. For occurrence dependence, if the function $g(\cdot)$ is stationary across spells $(l)$ then there is no occurrence dependence.

The state transitional framework has also been applied in the business cycle literature, particularly for the transitions between expansions and recessions. Several contrasting themes are noted in the application of transitional framework in this literature. First, the use of time-varying transitional probabilities is more appropriate to account for time-varying factors critical in identifying turning points along the business cycle. Therefore, time-varying transitional probabilities have more predictive power in business cycle forecasts. This view has been emphasized by Filardo (1994) and Filardo and Gordon (1998). In contrast to the labour economics literature, individual characteristics tend to change slowly and, therefore, fixed transitional probabilities have been used such as those from Ballen and Freeman (1986). Second, unlike in the labour economics literature, there remains considerable debate as to whether positive or negative duration dependence exists. Filardo and Gordon (1998) argue that contractions have positive duration dependence, while expansions do not. In contrast, Hamilton (1989) offers evidence of negative duration dependence such that the longer an economy experiences an expansion, the less likely it will experience a contraction. But Diebold 
and Rudebusch (1990) provide evidence that positive duration dependence exists in a complete cycle, while negative duration dependence exists in a half cycle.

In summary, both labour economics and business cycle literature have applied state-transition frameworks. Two approaches have been used. The first pertains to explaining the sources of variation in individual's transitional probabilities of moving between states, while the second deals with the factors related to the transitions between states.

\subsection{Application of State-Transition Framework on Capital Flows}

We first identify at each point in time whether a country is in a "normal", "surge" or "stop" episode of gross capital flows. Based on individual country series, we derive the individual transitional likelihood of moving from one episode to another. We then seek to understand which factors covary with the cross-country differences in transitional likelihoods. For illustration, Norway has a transitional likelihood of moving from "normal" to "stop" episode of gross capital inflows of around 6.8 percent, while Australia has about 1.2 percent. Pinning down the factors that explain this crosscountry variation is the primary goal of this paper.

In this regard, we also consider the role of state-dependence variables. However, we make several distinctions between labour economics state-dependence variables and those that are used in this paper. First, the assessment of state-dependence entails a pooled probit set-up that considers common factors across individuals like labour market conditions. It addresses questions like which factors increase or decrease the probability of moving between employment states. In contrast, this paper looks at the factors explaining the transitional likelihood themselves. Specifically, it focuses on factors that explain cross-sectional variation of transitional likelihood of moving between states.

Second, Heckman and Borjas (1980) differentiate between current and lagged duration dependence since they allow for time variation. In this paper, we consider duration as the total number of periods in a given state. We do not differentiate between current and lagged duration as we are interested in the cross-sectional covariation. ${ }^{15}$ For duration, we mean the total length of time a country spends in a given state. For occurrence, we mean the total number of times a country experiences a specific episode. These depart from Heckman and Borjas (1980).

In applying state-transition framework on episodes of capital flows, we consider two important aspects. First, we highlight the link between transitional likelihood and state dependence, consistent with Ballen and Freeman (1986) and Heckman and Borjas (1980). Specifically, higher transitional likelihood tends to be correlated with shorter episodes but more frequent occurrence. In contrast, lower transitional likelihood are associated with longer episodes but less frequent occurrence.

Second, crucial to the application of this conceptual framework is the focus on domestic factors. In the labour economics literature of employment transitions, overall economic conditions such as economic growth or unemployment rate do matter when one considers the transition from one state to another (Blau 1998, Bradley et al. 2003, and Martinez-Granado 2002). Their inclusion is motivated by the fact that they act as controls. But when we look at the transitional probabilities themselves in a cross-sectional set-up, common factors, say unemployment rate, are experienced by all individuals and so they do not change across sample (Ballen and Freeman, 1986). A similar line of reasoning can be applied to the transitional likelihood of episodes of capital flows. Global factors

\footnotetext{
${ }^{15}$ In the labour economics literature with current and lagged duration dependence, common factors are included since there is time variation. However, in applying duration dependence in a cross-sectional set-up, adding the total number of quarters or periods where an economy experiences a particular episode removes common factors.
} 
such as global growth, global liquidity, global interest rates, and global risk factor are common across countries and, therefore, are excluded in the empirical analysis. We show this by

$$
C F_{i, t}=\alpha_{i}+X_{t} \gamma+Y_{i, t} \beta+\varepsilon_{i, t}
$$

where $C F_{i, t}$ captures capital inflows to country $i$ at time $t ; X_{t}$ is a vector of global factors at time $t$; $Y_{i, t}$ is a vector of domestic factors for country $i$ at time $t ; \alpha_{i}$ is a constant; and $\varepsilon_{i, t}$ is the error term. Suppose, we take the mean of Equation (2) through time (t),

$$
\overline{C F_{i}}=\alpha_{i}+\bar{X} \gamma+\bar{Y}_{i} \beta+\bar{\varepsilon}_{i}
$$

Since $\bar{X} \gamma$ is a constant which does not vary across country (i), we denote

$$
\alpha_{i}^{*}=\alpha_{i}+\bar{X} \gamma
$$

So, we have:

$$
\overline{C F_{i}}=\alpha_{i}^{*}+\bar{Y}_{i} \beta+\bar{\varepsilon}_{i}
$$

Based on Equations (3) and (4), the average of global factors does not vary across countries in the sample. Hence, global factors are dropped from our empirical specification. Equation (5) tells us that average of capital flows for country $i$ is related to its domestic factors; and some country-specific constant $\alpha_{i}^{*}$ as shown in Equation (4). Similarly, other fixed-time statistics such as transitional likelihood will only depend on domestic factors.

The focus on domestic factors in explaining cross-country variation in transitional likelihoods or state-dependence factors can be best discussed using an example. Consider five economies in a surge episode from 1Q2007 to 3Q2008 and only four economies transitioned to a stop episode when global risk aversion rose in 4Q2008. Cross-country differences in transitional likelihoods would have then been explained by domestic factors in this case as global risk is common to all. Specifically, what is with the fifth economy that caused it to remain in a surge episode given that global risk is high. For that economy to remain in a surge episode must be caused by its own idiosyncratic factor.

Figure 2.1 illustrates our conceptual framework on the relevance of domestic factors to statedependence variables and transitional likelihoods. Our findings show strong covariation between transitional likelihoods and state-dependence variables. However, both duration and occurrence also covary with domestic factors. We then illustrate that a domestic factor, such as less capital account restrictions, is significantly correlated with more frequent stops. More frequent stops are significantly correlated with lower likelihood of remaining in a stop episode but higher likelihood of transitioning to another episode. In contrast, higher foreign reserves are significantly associated with longer normal episodes, which also relate to lower likelihood of transitioning to an extreme episode. This demonstrates that domestic factors can operate through either "duration" or "occurrence" which, in turn, covary with transitional likelihood of moving between episodes. 


\section{Empirical Specification}

To answer the second to fourth questions set out in this paper, we estimate two regression specifications. First, we estimate conditional correlations of transitional likelihoods on statedependence variables in order to assess the importance of past experience, in terms of length and frequency, of being in an episode on the likelihood of transitioning between types of episode. We follow the specification

$$
\mathrm{P}_{i, x, y}=\alpha_{0}+\beta_{1} D_{i, x}+\beta_{2} D_{i, y}+\beta_{3} O_{i, x}+\beta_{4} O_{i, y}+\varepsilon_{i}
$$

Second, given the strong correlation between transitional likelihood and state-dependence variables, we test which domestic factors are significantly correlated with state-dependence variables following the specification

$$
\begin{aligned}
& Z_{i}=\alpha_{0}+\beta_{1} \text { VOL }_{i}+\beta_{2} \text { GDPPC }_{i}+\beta_{3} \text { CRED }_{i}+\beta_{4} M K C A P_{i}+\beta_{5} \text { TRADE }_{i}+ \\
& \beta_{6} \text { FINOPEN }_{i}+\beta_{7} \text { KAOPEN }_{i}+\beta_{8} N F A_{i}+\beta_{9} F_{X R_{i}}+\varepsilon_{i}
\end{aligned}
$$

where $P_{i, x, y}$ refers to the transitional likelihood from episode $x$ to episode $y$ of country $i ; Z_{i}$ refers to state-dependence variables such as $D_{i, x}, D_{i, y}, O_{i, x}$, and $O_{i, y} ; D_{i, x}$ is the duration for episode $x$ of country $i ; D_{i, y}$ is the duration for episode $y$ of country $i ; O_{i, x}$ is the occurrence for episode $x$ of country $i ; O_{i, y}$ is the occurrence for episode $y$ of country i. VOL $L_{i}$ is output volatility; $G D P P C_{i}$ is per capita income; $C R E D_{i}$ is domestic credit; $M K C A P_{i}$ refers to stock market capitalization; $T R A D E_{i}$ is trade openness; FINOPEN $N_{i}$ is de facto financial openness; $K A O P E N_{i}$ is de jure capital account openness; $N F A_{i}$ is net foreign assets; $F X R_{i}$ is foreign exchange reserves; and $\varepsilon_{i}$ is the error term. To address whether the pattern holds for different types of capital flows, we estimate equation (7) separately for total, debt, and equity inflows. Equations (6) and (7) are estimated using ordinary least squares with robust standard errors. ${ }^{16}$

Given our empirical specifications and variable choices, we note several caveats. First, domestic variables pertain to structural characteristics of a country. This is consistent with the use of fixed transitional likelihoods. As pointed out by Koepke (2015), most domestic variables in the literature on capital flows can be broadly classified as either cyclical or structural. Domestic factors included in Equation (7) pertain to structural variables as they change slowly through time.

Second, the empirical specifications are limited to conditional correlations and do not establish causation. We do not make any attempt to establish causation as we are simply interested in looking at covariation between transitional likelihoods and state-dependence variables; and between statedependence variables and domestic factors. Although we do not claim causality, the analysis remains relevant as we are able to say which domestic factors are correlated with longer and more frequent episodes, which covaries with transitional likelihood of moving between episodes. We can, thereby, infer a country's vulnerability in experiencing extreme episodes.

Third, we do not rule out that domestic factors can also be correlated with transitional probabilities. In fact, when we ran a separate regression of transitional likelihoods on domestic and statedependence variables and transitional likelihoods on domestic variables, some domestic factors

\footnotetext{
${ }^{16}$ We cannot run a seemingly unrelated regression as our dependent variable for both transitional likelihoods and state-dependence variables sum to 100 percent, in which case the results indicate near singular matrix.
} 
appear statistically significant. ${ }^{17}$ But the significance of state-dependence variables holds and the residual sum of squares for the regression of transitional likelihoods on domestic factors is very large while the R-square is lower. We take these as evidence of a stronger covariation between transitional likelihood and state-dependence variables. Hence, we estimate equation (6).

Fourth, Equation (6) does not necessary imply mechanical results. Since we are also interested to know whether there is evidence of positive or negative duration dependence, the signs of the coefficients will be indicative. For occurrence, the sign of the estimated coefficients are also indicative on whether the more frequent one experiences an episode that more or less likely one will exit that episode. But there is no a priori reason to assume the relation of both state-dependence variables for it is possible that a country could have experienced long duration of a given episode but could have experienced that episode spell more or less frequently. ${ }^{18}$ Given these two reasons, the regression results in Equation (6) may not necessarily be mechanical.

Fifth, Equation (7) allows us to assess under which state-dependence variables domestic factors relate to transitional likelihood. It would be possible that some factors may correlate more with either or both state-dependence variables.

Lastly, Equations (6) and (7) are estimated using ordinary least squares against alternative methods for the following reasons. Regime switching models would consider time-varying component and would not particularly address cross-country variations. Simultaneous equations would take both state-dependence and domestic factors into account in explaining cross-country variation in transitional likelihoods at the same time. Given that the relation between state dependence and domestic factors are also important, it is better to do a step-by-step analysis wherein transitional likelihood is regressed on state dependence variables as in Equation (6); and then state-dependence variables on domestic factors as in Equation (7). Non-linear models would require choosing the right specification whether it be log, double log or log-linear form. For simplicity and clarity of estimation approach, ordinary least squares estimation is used.

\section{Data and Stylized Facts}

In order to address the questions in this paper, three important data considerations are made. First, we define the three episodes of gross capital inflows. Second, we compute fixed transitional likelihoods for each country in the sample. Third, we derive duration and occurrence.

\subsection{Episodes of Gross Capital Inflows}

On the definition and measurement of extreme episodes, various authors have used different data sources and identification strategy. On data, Calvo et al. (1993) and Reinhart and Reinhart (2009) developed proxy data on net capital inflows to capture sudden stops and surges, respectively, using current account and foreign reserves data as these variables are available for longer period and more countries. However, more recent papers, including those from Caballero (2014), Calderon and Kubota (2013), Faucette et al. (2005), Forbes and Warnock (2012a and 2012b), and Rothenberg and Warnock (2011), use Financial Accounts data of the Balance of Payments Statistics in defining extreme episodes of gross capital inflows. In summary, data on extreme episodes found in the literature varies between the use of proxy and actual Financial Accounts data, as well as the use of

\footnotetext{
${ }^{17}$ Results are presented in Tables 2.A1 and 2.A2 in Appendix 2.1.

${ }^{18}$ Given that transitional likelihoods and state-dependence variables stem from hazard (exit) functions as shown in Equation (1), we estimate the correlations of transitional likelihoods on both duration and occurrence in Equation (6). But given that there could be an implied negative correlation between duration and occurrence, we also regressed transitional likelihoods on each of the two statedependence variables (duration and occurrence) separately in Tables 2.A3 and 2.A4 in Appendix 2.1. We note that the estimated results are in line with the baseline results presented in Table 2.4 .
} 
gross or net capital inflows. The consequence of using proxy versus actual flow data, and gross versus net flows have profound implications on the results since the number and dating of the identified episodes depend on these choices. ${ }^{19}$ In this paper, we use gross capital inflows to focus on foreign-driven capital flows and assume domestic and foreign investors could behave differently.

Various methods are used to identify extreme episodes in the literature. The most popular approach in identifying "stops", albeit with varying degrees of modifications, is the use of deviations from some benchmark value. Calderon and Kubota (2013), Calvo et al. (2008), Cavallo and Frankel (2008), Forbes and Warnock (2012a and 2012b), and Rothenberg and Warnock (2011) used one or two standard deviations from the historic sample mean in identifying and dating "stops". For "surges", the most common method is the use of top percentile of the sample inflow. ${ }^{20}$ Reinhart and Reinhart (2009) define "surges" as the top $20^{\text {th }}$ percentile, while Ghosh et al. (2014) used top $30^{\text {th }}$ percentile.

On the identification of episodes of gross capital flows in this paper, we follow Forbes and Warnock's (2012a) approach in identifying extreme episodes. ${ }^{21}$ We follow the definition of Forbes and Warnock (2012a and 2012b) because they impose stricter conditions of what extreme episodes are. In fact, these criteria entail more disruptive impact of extreme episodes. We use Financial Accounts data from the Balance of Payments Statistics of the International Monetary Fund and national sources (for countries with unavailable IMF data) for the period 1970Q1 to 2014Q4 for 55 advanced and emerging economies. Total capital inflows refer to the sum of debt and equity inflows. Debt inflows include portfolio debt and other investment inflows, while equity inflows include foreign direct investment and portfolio equity inflows.

To restate, Forbes and Warnock (2012a and 2012b) define a "surge" as an episode where gross capital inflows increase more than one standard deviation above its historic mean provided that: (i) it reaches at least two standard deviation above at some point within that episode; (ii) the entire episode lasts more than one quarter; and (iii) there are at least four years of data to calculate the historic mean. ${ }^{22}$ Specifically, we let $C_{t}$ be the four-quarter moving sum of gross capital inflows (GINFLOW) and derive annual year-on-year changes in $C_{t}$ :

$$
\begin{gathered}
C_{t}=\operatorname{GINFLOW}_{t}+\text { GINFLOW }_{t-1}+\text { GINFLOW }_{t-2}+\text { GINFLOW }_{t-3}, \\
\Delta C_{t}=C_{t}-C_{t-4},
\end{gathered}
$$

Rolling average and standard deviations of $\Delta C_{t}$ are computed over the last 20 quarters. ${ }^{23} \mathrm{~A}$ "surge" episode is defined to start at the first month $t$ when $\Delta C_{t}$ increases more than one standard deviation above the rolling mean. But in order for an entire episode to qualify as "surge" there must be at least one quarter $t$ when $\Delta C_{t}$ increases up to two standard deviations above its historic mean. $\mathrm{A}$ "stop" episode is defined using the same approach but pertains to opposite direction. We define "normal" episodes as the absence of an extreme episode for a given quarter.

Several distinctions are noted from the identified episodes in comparison to Forbes and Warnock (2012a and 2012b). ${ }^{24}$ First, for total gross flows, there are marked differences in the identified episodes accounting for the fact that Forbes and Warnock (2012a) used net error and omissions to

\footnotetext{
${ }^{19}$ As illustrated by Faucette et al. (2005) and Rothenberg and Warnock (2011), using actual gross flows significantly reduce the number of Calvo's "sudden stops" compared to using current account and reserve accumulation data as proxy for net capital inflows.

${ }^{20}$ See Crystallin et al. (2015) for a survey and assessment of the methodologies used in defining "surges".

${ }^{21}$ See Appendix 2 for a discussion of capital flow data and Table A5 for country classifications.

${ }^{22}$ The value for current quarter is excluded in computing the historic mean and standard deviation.

${ }^{23}$ To maximize available data, a four-year rolling mean and standard deviation are used at the start of the series (Forbes and Warnock, 2012a and 2012b).

${ }^{24}$ Table A6 in Appendix 3 presents the identified "surge" and "stop" episodes for total, debt, and equity inflows.
} 
fill in missing data. In this paper, no such attempt to clean the data was made so as to rely primarily on the classified financial transactions in the Balance of Payments Financial Accounts. Second, unlike Forbes and Warnock (2012b), we defined extreme episodes for debt and equity inflows following the abovementioned criteria, and not whether they are debt-led or equity-led episodes. Forbes and Warnock (2012b) tested which factors hold when extreme episodes are driven by debt and equity inflows. In contrast, this paper tests the relevance of domestic factors on transitional likelihood when there are "surges" and "stops" in gross debt and equity inflows. Following Forbes and Warnock (2012b) might not add so much to our analysis as most factors are correlated with debt-led episodes. Third, the starting and ending quarters of identified episodes can be different from Forbes and Warnock (2012a) as we reclassified extreme episodes separated by one quarter of normal episode to the succeeding extreme episode. For instance, some countries in 2008Q3 have normal episode between a surge episode in 2008Q2 and stop episode in 2008Q4. We reclassify the normal episode identified in 2008Q3 as a stop episode to account for the fact that the global and domestic conditions prevailing during that quarter actually correspond to conditions in the stop episode.

To illustrate the method of identifying extreme episodes, Figure 2 extends Forbes and Warnock's (2012a) data for Brazil. ${ }^{25}$ Notice that the pattern shows striking resemblance to Figure 2 in Forbes and Warnock (2012a). Figure 3 shows the frequency of countries experiencing extreme episodes for total, debt, and equity inflows. We note several observations. First, similar to Forbes and Warnock (2012a), there is unprecedented number of countries who experienced "surges" before the global financial crisis of 2007-08 and also unprecedented number of countries who had "stops" during the crisis. Second, for surges, there tend to more countries experiencing equity surges than debt surges. This pattern is not observed in Forbes and Warnock (2012b) as they analysed debt- and equity-led episodes separately. Third, we observe periods when more countries experience extreme episodes compared to other periods. For example, there are spikes in the number of countries experiencing "stops" in the early 1980s, early 1990s, 1997-1998, early 2000s, and 2007-2009. These periods coincide with crises periods or economic downturns. Although there are differences between this paper and Forbes and Warnock's (2012a and 2012b) identified episodes, the general patterns observed in this paper are consistent with Forbes and Warnock (2012a).

\subsection{Transitional Likelihood Data and Stylized Facts}

To compute for transitional likelihoods, we use a one-step transitional likelihood specification, where we denote $E P_{t}$ (episode) as taking the value of 0 for normal episode, 1 for surge episode, and -1 for stop episode. The transitional likelihood then takes the form

$$
\mathrm{P}_{x, y, t}=\mathrm{P}\left\{E P_{t}=x \mid E P_{t-1}=y\right\},
$$

where $x$ is the origin episode and $y$ is the destination episode. We apply the above specification on our computed episode series for total, debt, and equity inflows. For illustration, the likelihood of moving from "normal" to "surge" episode is calculated as the ratio of the number of times a country transitions from "normal" to "surge" divided by the total number of transitions coming from a "normal" episode. Transitional likelihoods for "surges" and "stops" are computed in the similar way.

One important point we highlight in this approach is that we compute a single transitional likelihood for the entire sample period or what is known as "fixed transitional probability", such that each country only has one transitional likelihood of moving between an episode type to another for the

\footnotetext{
${ }^{25}$ We note that the underlying series is stationary given that we have taken changes of the rolling average.
} 
entire sample period. ${ }^{26}$ We use this approach as we want to assess which factors covary with transitional likelihoods and state dependence variables. Using such approach, a cross-section set-up would be reasonable as it focuses on which factors correlate with transitional likelihoods and statedependence variables. Knowing that global factors are common to all countries, it would then highlight the relevance of domestic factors. We can then interpret the transitional likelihood as an indicator of a county's vulnerability of experiencing an extreme episode.

Another consideration pertains to the use of actual episode data in accounting for transitional likelihoods. Since we do not assume specific probability function, the computed transitional likelihoods could be interpreted based on the realized past transitions of economies across episodes. This approach warrants the interpretation of transitional likelihood as an indicator of propensity or vulnerability of transitioning to various episodes.

We note several observations in our computed transitional likelihoods. ${ }^{27}$ First, the transitional likelihood of moving from a normal episode to an extreme episode is very low. For instance, the likelihood of transitioning from "normal" to "surge" episode for the United States is about 7 percent, while that from "normal" to "stop" is only 2 percent. Second, the likelihood of staying in an extreme episode is relatively high such that the likelihood of staying in "surge" is 73 percent and in a "stop" 81 percent for the United States. Third, the probability of exiting an extreme episode is lower than that for staying in an extreme episode. That is the likelihood of exiting a "surge" episode and moving into "normal" episode is only 14 percent for the United States but the likelihood of staying in a "surge" episode is around 73 percent. Fourth, the sudden swing from one extreme episode to another also occurs. For instance, in the United States, the likelihood of transitioning from a surge to a stop episode is around 14 percent. Fifth, these patterns hold true for both debt and equity inflows. These observations imply that the likelihood of entering an extreme episode is small, but, if it happens, the likelihood of staying in that extreme episode is high. This is a new finding obtained from applying state-transition framework on episodes of gross capital inflows.

Table 1 provides summary statistics on transitional likelihoods for advanced and emerging country groups for total, debt, and equity inflows. We note several facts. First, there are cross-country differences in the transitional likelihoods of moving between episodes. The standard deviation ranges from 2 to 7 percent and holds true for total, debt, and equity inflows. It is usually larger for transitions originating from extreme episodes like "surge" to "normal" or from "stop" to "normal". Second, the variation across emerging countries is mostly larger than those for advanced countries for all types of flows and transitions. Third, using a neutral measure of dispersion, the coefficient of variation suggests that cross-country differences in the transitional likelihoods are largest for movements between extreme episodes. For instance, there is higher variation in the likelihood of moving from "surge" to "stop" and from "stop" to "surge" than for other transitions. These observations illustrate cross-country differences in the transitional likelihoods and these differences also vary across movements between episodes.

\subsection{State-Dependence Variables and Stylized Facts}

Given that the transition depends only on the previous state, we take into account statedependence variables, namely "duration" and "occurrence". We define "duration" as the ratio between the total quarters a country spends in an episode to total quarters in the sample scaled to 100

\footnotetext{
${ }^{26}$ Another approach would be to take time-varying transitional probability following Filardo (1994). However, this might not be an appropriate method for this study as we are more concerned with explaining cross-country differences in transitional likelihoods and not the actual transition from one episode to another.

${ }^{27}$ Tables A7 to A9 in Appendix 4 show the transitional likelihoods for each country in our sample for total, debt, and equity gross inflows, respectively.
} 


$$
D_{i}=\frac{n\left(E P_{t}=x\right)}{T}
$$

where $i$ is country, $x$ is episode (EP) type, $n$ refers to number or count, $t$ is period or quarter, and $T$ is the total number of quarters or periods in the sample. ${ }^{28}$ We define "occurrence" as the ratio between the number of times a country experiences an episode to the total number of episodes a country has regardless of type. The number of times a country experiences an episode type is given by an index function

$$
S_{i}=1_{\left\{E_{1}=x\right\}}+\sum_{t=2}^{T} 1_{\left\{E_{t}=x, E_{t-1} \neq x\right\}},
$$

where $S_{i}$ is the episode type count. Thus, occurrence is given by

$$
O_{i}=\frac{S_{i}}{S}
$$

where $i$ is country and $S$ is the total number of episodes a country has regardless of episode type. Values are scaled to 100 . Table 2 provides summary statistics on the computed state-dependence variables. ${ }^{29}$ Here, we find that, on average, each country spends around 71 percent of its time in a "normal" episode, around 15 percent in "surge" episode, and 14 percent in "stop" episode. Across country groupings, emerging economies spend relatively longer time in "normal" episodes than advanced economies, while advanced economies spend relatively longer time in "stop" episodes than emerging economies. In addition, we find that variation is mostly greater for emerging economies than for advanced economies. Table 2 also reveals that "normal" episodes occur more frequently, while "stops" and "surges" occur at relatively the same frequency. Noticeably, this pattern appears consistent across country groups. However, cross-country difference in occurrence appears larger for advanced economies than for emerging economies. These observations highlight that "normal" episodes last longer and are more frequent than extreme episodes, and there are marked differences across countries.

Figure 4 illustrates the relation between "duration" and "occurrence" and transitional likelihood for total capital inflows. The top panel of Figure 4 shows that the longer one spends in an episode, the more likely one will stay, the more likely one will transition to that episode, and the less likely one will exit from the episode. These demonstrate the presence of negative duration dependence. The bottom panel of Figure 4 shows the more frequent one experiences an episode, the less likely one will remain in that episode and more likely it will transition to another episode but it is also more likely to move to that episode from another episode. Taken together, Figure 4 illustrates the relation between the state-dependence variables and transitional likelihoods.

\subsection{Domestic Factors and Stylized Facts}

For domestic factors included in Equations (6) and (7), output volatility refers to the standard deviation of real GDP growth, taken from the World Economic Outlook Dataset April 2015. Following Calderon and Kubota (2013), we expect countries with more stable macroeconomic conditions to have a lower likelihood of transitioning to a stop episode. Per capita income is in natural logarithm

\footnotetext{
${ }^{28}$ We use the total number of periods or quarters in an episode instead of averages in line with understanding of cross-country variations. Forbes and Warnock (2012a) find that, on the average, countries spend four quarters in an episode. If one considers the average duration, there will be fewer variation in a cross-country set-up as most would have 4 quarters as average.

${ }^{29}$ Tables A10 to A12 in Appendix 4 present the computed duration and occurrence for each country in the sample for total, debt, and equity gross inflows, respectively.
} 
of per capita income at constant US\$2010 prices taken from World Development Indicators (WDI) of World Bank. Similar to Cavallo et al. (2008), per capita income controls for the level of development of a country. Domestic credit pertains to the loans to private sector as percentage of GDP taken from WDI. We expect domestic credit to be correlated with both "surges" and "stops" as pointed out by Caballero (2014), Cavallo et al. (2008), Magud et al. (2014), and Sula (2010). Stock market capitalization of listed companies relative to GDP is sourced from WDI and national sources accessed through CEIC Database. It accounts for the level of financial development of a country. As pointed out by Cavallo et al. (2008), countries with higher trade openness tend to be less vulnerable to "stops" as perceived default probability is lower. Data on trade openness refer to merchandise exports plus imports relative to GDP taken from WDI.

Caballero (2014), Calderon and Kubota (2013), Calvo et al. (1996 and 2008), Ghosh et al. (2014), and Magud et al. (2014) pointed out the importance of financial integration in exacerbating the occurrence of "surges" and "stops". We use two measures. First is a de facto financial openness measure using the sum of total foreign assets and total foreign liabilities as percentage of GDP sourced from External Wealth of Nations or EWN Mark II (Lane and Milesi-Ferretti 2007). Second is a de jure measure of capital account openness using Chinn-Ito standardized index (2006) scaled by $100 .^{30}$ Park and Mercado (2014) highlight the divergence of both measures. We also include net foreign asset position to characterize whether a country is a net creditor or net debtor. As pointed out by Lane and Milesi-Ferretti (2002), the net foreign asset position of a country reflects the level of public debt and the demographic structure of a country. Following Calvo et al. (1993 and 1996), we also include foreign reserves as part of country characteristics. Both net foreign asset position and foreign reserves as ratios to GDP are taken from External Wealth of Nations Database.

The regressors in Equation (7) are annual averages from 1980 to $2014 .^{31}$ Table 3 presents summary statistics of the average values of the regressors. We note that advanced economies, on average, have higher per capita income, domestic credit, market capitalization, and de facto and de jure financial openness. Emerging economies, on the other hand, have higher macroeconomic volatility, trade openness, and foreign reserves.

\section{Empirical Analysis}

\subsection{Baseline Results}

Table 4 presents the results on the conditional correlations between the transitional likelihoods and state-dependence variables, following Equation (6). The results show state-dependence variables, "duration" and "occurrence", are strongly related with transitional likelihood of moving between episodes. The model fit is relatively good. ${ }^{32}$ Table 4 reveals several important findings. First, economies that stay longer in a normal episode have significantly higher likelihood of being in a normal episode and lower likelihood of moving to another episode. Specifically, a one percent increase in the duration of being in a normal episode is highly correlated with a higher likelihood of remaining in a normal episode by 0.28 percent, while significantly associated with lower likelihood of

\footnotetext{
${ }^{30}$ Since the latest Chinn-Ito index is available until end-2013, we use 2013 values for our 2014 sample. Data for Taiwan is proxied by data for Korea as the level of de facto financial integration between these two countries are the closets among the countries in the region.

${ }^{31}$ Table A13 in Appendix 5 shows data definition and sources for the domestic factors. In cases wherein a country's data start on a later year, we follow the starting date of episodes in taking the average values of the regressors.

${ }^{32}$ We also estimate transitional likelihood on both state-dependence and domestic factors (Table A1 in Appendix 1). The results indicate that aside from state-dependence variables, domestic factors such as output volatility, market capitalization, financial openness, and foreign reserves are also significantly correlated with transitional likelihoods. We also tested the conditional correlation between transitional likelihoods and domestic factors excluding state-dependence variables (Table A2 in Appendix 1), the results show lower Rsquared and higher residual sum of squares. We take these as evidence that transitional likelihood covary strongly with state-dependence variables than with domestic factors.
} 
moving to a surge episode by 0.16 percent and moving to a stop episode by 0.11 percent. Taken together, these findings offer support to the presence of negative duration dependence.

Second, countries that experience an episode more frequently tend to have significantly lower likelihood of staying in that episode but a higher likelihood of transitioning to and from another episode. For instance, higher frequency of experiencing normal episodes is significantly associated with lower likelihood of remaining in a normal episode by around 0.30 percent but significantly higher likelihood of moving from normal to surge episode by 0.16 percent, normal to stop episode by 0.23 percent, surge to normal episode by around 1 percent, and stop to normal episode by 0.50 percent. Consequently, duration appears significant for transitions from the origin episode, while occurrence is significant for both origin and destination episodes. These results hold true for debt and equity inflows. These also validate that the estimates do not capture mechanical results as we find that duration of destination episodes to be insignificant. For instance, duration of surge is insignificant for the transitional likelihood of moving from normal to surge. If the results are mechanical, then duration of surge should also be significant. Also, we find that the more frequently one experiences an episode, the less likely one remains in that episode, which is contrary to the mechanics in the labour economics literature wherein the more frequently one experiences an episode the more likely one remains in that episode (Heckman and Borjas, 1980).

To assess the importance of domestic factors on transitional likelihoods and to know which statedependence variables domestic factors influence, we test the conditional correlation between statedependence variables and domestic factors, following Equation (7). Tables 5, 6, and 7 present the results of the conditional correlations of state-dependence variables on domestic factors for total, debt, and equity inflows, respectively.

For total gross inflows in Table 5, the estimates show that countries with higher output volatility tend to have less frequent normal episodes by around 0.82 percent. This result is robust in our sensitivity tests. This could mean higher output volatility is linked to the occurrence of surge and stop episodes. However, since our volatility measure does not capture whether output growth is either positive or negative, we do not find its significance on the occurrence of either surge or stop episodes in Columns (5) and (6). The results also indicate that countries that are more financially open usually have significantly shorter stop episodes, while those that have less capital restrictions tend to have more frequent stop episodes. Both measures imply that economies that are more financially open usually experience shorter but more frequent stops. These results are robust in our sensitivity tests, and clearly highlight that both financial openness measures operate via two different state-dependence variables. Finally, our estimates for gross inflows indicate that economies with larger foreign reserves usually have longer normal episodes. The result is robust and indicates that foreign reserves significantly covary with the duration of normal episodes.

For debt inflows in Table 6, countries with higher domestic credit usually have significantly longer debt surges. This result is robust in our sensitivity tests and in line with the literature on domestic credit and surges (Caballero, 2014 and Magud et al., 2014). Economies with more developed financial system tend to experience less frequent normal debt episodes but more frequent surge debt episodes. Unlike the results for total gross inflows in Table 5, those with higher foreign reserves tend to have experienced less frequent debt surges but more frequent debt stops. This result is in line with the experience of emerging countries in the 1990s where sudden stops of capital inflows preceded greater reserve accumulation as the latter became the first line of defence against excessive currency depreciations. It also suggests that, unlike for gross capital inflows, foreign reserves significantly covary with the occurrence of extreme debt episodes. 
For equity inflows in Table 7, economies with higher per capita income tend to have significantly less frequent equity surges. However, this finding is not robust in our sensitivity tests. The results also show that countries that are more open to trade experience significantly less equity stops. This finding holds in our sensitivity tests and concurs with the results of Cavallo et al. (2008) who argue that countries with higher trade openness tend to be less vulnerable to stops as the perceived default probability is lower. The results also indicate that more financially open economies usually experience longer equity surges but more frequent equity stops, while economies with less capital restrictions tend to have significantly longer episodes of normal equity flows but shorter equity surges. Lastly, countries with higher foreign reserves tend to have more frequent equity stops consistent with the results for debt inflows and in line with emerging economies' experience in the 1990s. The findings on the significance of foreign reserves clearly indicate that it is highly relevant for the duration of total gross inflows but matters more for the occurrence of debt and equity episodes.

These results show which domestic factors significantly covary with the length and frequency of experiencing various episodes of capital inflows. Furthermore, these results demonstrate that domestic factors can covary either with duration or occurrence or with both state-dependence variables. But we see differences in the relevance of domestic factors for different types of capital flows. Given these differences, it is clear that domestic factors are related to state-dependence variables. In turn, as shown in Table 4, state-dependence variables are significantly correlated with transitional likelihoods of moving between episode types. In fact, one of key findings is that under cross-sectional framework, there is evidence of negative duration dependence similar to the employment transition literature.

We make several important points from the baseline findings. First, the results rest on small number of observations. Given that there are 55 economies in the sample, the significance of each domestic variable is sensitive to which countries are included. Nonetheless, the country composition used in the estimation is indicative of the overall significant covariation between transitional likelihood and state-dependence variables as well as state-dependence variables and domestic factors.

Second, very few domestic factors appear significant particularly for state-dependence variables. In fact, among the domestic factors considered, de facto and de jure financial openness measures and foreign reserves are those that consistently appear significant. Two possible explanations are provided. First, cross-country variations in state-dependence variable can be small. As indicated in Table 2, the standard deviation for state-dependence variables ranges from 3 to 7 percent. This could explain why very few domestic factors appear significant. The relatively small cross-country variation could be attributed to the fact that the results are capturing country idiosyncratic (domestic) factors. Given that we abstract from global factors, which are common to all countries, differences in duration, occurrence, and transitional likelihoods are explained by individual country factors. In effect, abstracting from global factors, we have accounted for the cross-border synchronization of capital inflows, and so what is left to explain cross-country variations are domestic factors that enable a country to hold up against synchronized movements in capital inflows. Another explanation could be that there are, indeed, few domestic factors relevant for explaining state-dependence variables. Since this paper is the first paper to study capital flow transitions from a cross-country setting, the results offer initial findings for future researches.

\subsection{Sensitivity Tests}

We conduct several sensitivity tests to validate the baseline results. First, since our sample includes country outliers, we exclude those that have huge cross-border asset holdings relative to the size of the economy such as Ireland and Singapore that have very large de facto financial openness 
indicator. This reduces the sample size from 55 to 53 economies. Second, since the net foreign asset position is highly linked to foreign debt liabilities, we replace our measure of net foreign asset position with foreign debt liabilities to GDP ratio in Equation (7). ${ }^{33}$ Third, given too many domestic factors are included in equation (7), we focus on per capita income as a measure of economic development, market capitalization to capture the level of financial development, de facto financial openness, and foreign reserves. Lastly, since some of the domestic factors are correlated, we test the individual significance of each domestic factor with the two state dependence variables using bivariate regressions. The results from our sensitivity tests are presented in Tables 8, 11, 14, and 17 for total capital inflow episodes; Tables 9, 12, 15, and 18 for debt episodes, and Tables 10, 13, 16 and 19 for equity episodes.

For total capital inflow episodes in Tables 8, 11, 14 and 17, we find the significance of output volatility, de facto and de jure financial openness, and foreign reserves hold. But there are differences from the baseline results. Excluding Ireland and Singapore, both de facto and de jure measures are no longer significant for total capital inflow episodes. This result is not surprising as both countries are highly open relative to the size of their economies. For all sensitivity tests on total gross inflow episodes, foreign reserves appear significant for the duration of surge episodes, which is not the case in the baseline results. Specifically, countries that have larger foreign reserves tend to experience significantly shorter surges. This implies that foreign reserves have inverse relation with extreme episodes as the sign for duration of stop episodes is also negative but insignificant. For the bivariate regression in Table 17, financial openness is insignificant and there are other domestic factors such as net foreign assets which are now significant. However, results from the bivariate regression must be treated with caution as they overestimate the significance of the explanatory variable. ${ }^{34}$ Although there are differences from the baseline results, we do find evidence that output volatility, de facto and de jure financial openness, and foreign reserves significantly covary with the duration and occurrence of total capital inflow episodes.

In relation to debt inflow episodes in Tables $9,12,15$, and 18, we find that the significance of domestic credit, market capitalization and foreign reserves hold. Again, there are differences from the main results. Removing the two outliers, trade and financial openness become significant. For example, countries that trade more usually experience significantly less debt stops, while those that are more financially open tend to experience longer normal episodes of debt flows, less frequent debt surges, but more frequent debt stops. Foreign reserves consistently appear significant with the same sign in Tables 9 and 12 for debt inflows, suggesting that foreign reserves are highly linked with the occurrence and not with the duration of debt episodes. We also note that some domestic factors have turned significant. Per capita income is now significant for the duration of debt stops in Table 15 , suggesting that more developed economies tend to have longer debt stops. For the bivariate regressions in Table 18, foreign reserves are insignificant. Although there are differences from the baseline results, we do find evidence that domestic credit, level of financial development and foreign reserves significantly covary with the duration and occurrence of debt inflow episodes.

For episodes of equity inflows in Tables 10,13,16, and 19, we find that the significance of trade and de jure financial openness and foreign reserves hold. De facto financial openness, which is significant in the baseline results, is no longer significant in Tables 13 and 16 . The significance and sign of de jure financial openness are consistent with the baseline results. The sensitivity tests indicate that economies with less capital restrictions tend to have longer normal episodes of equity inflows and shorter equity surges. This implies that de jure financial openness is highly relevant for equity episodes and is linked to duration and not occurrence. Consistent in Tables 10, 13 and 16 is the

\footnotetext{
${ }^{33}$ Data on foreign debt liabilities are also taken from External Wealth of Nations (Lane and Milesi-Ferretti, 2007). Catão and Milesi-Ferretti (2014) find that foreign debt liabilities are a good predictor of external crisis.

${ }^{34}$ This is true for both debt and equity inflow pairwise regressions between duration and occurrence and each of the domestic factors. This explains why some of the domestic factors in Tables 17, 18, and 19 have become marginally significant.
} 
significance of trade openness on frequency of stops and the relevance of foreign reserves on the occurrence of equity episodes. This clearly supports the baseline results as it demonstrates that both trade openness and foreign reserves are relevant for the occurrence of equity episodes. Again some domestic factors have become significant in the sensitivity test for equity flows. For example, market capitalization is significant for the occurrence of equity surges in Table 10, while per capita income is significant for the duration of equity surges and occurrence of equity stops in Table 16. For Table 19, de jure financial integration measure appears most robust, and per capita income is now strongly significant. Although there are differences from the baseline results, we do find support that trade openness, de jure financial openness and foreign reserves significantly covary with the duration and occurrence of equity inflow episodes.

\section{Concluding Remarks}

This paper contributes to the literature on extreme episodes of gross capital flows by analysing the factors that significantly covary with cross-country transitional likelihoods of moving between episodes of gross capital inflows. Under a cross-sectional framework, we abstract from global factors in explaining cross-country variation in transitional likelihoods and state-dependence variables. Employing state-transitional framework for the episodes of gross capital inflows, we find that the likelihood of transitioning to an extreme episode is relatively small but the likelihood of remaining in an extreme episodes is relatively high.

We find that transitional likelihoods strongly covary with the duration and occurrence of episode types. The correlations indicate that the longer one experiences an episode type, the less likely an economy will exit from that episode. Hence, under a cross-sectional set-up, there is evidence of negative duration dependence. This paper also shows that state-dependence variables significantly covary with domestic factors, and that the covariance can either be in one or in both duration and occurrence. The correlation between state-dependence and domestic factors, as demonstrated in this paper, has not been fully explored in the current literature. 
Figure 1: Conceptual Framework

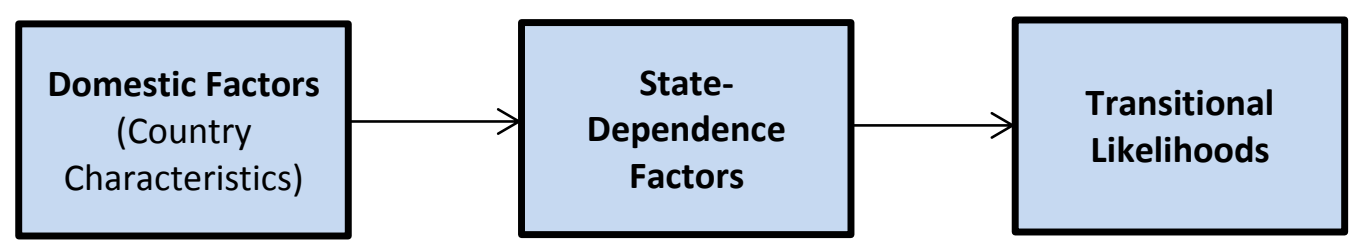

Note: State dependence factors include "duration" and "occurrence". 
Figure 2: Capital Inflows to Brazil

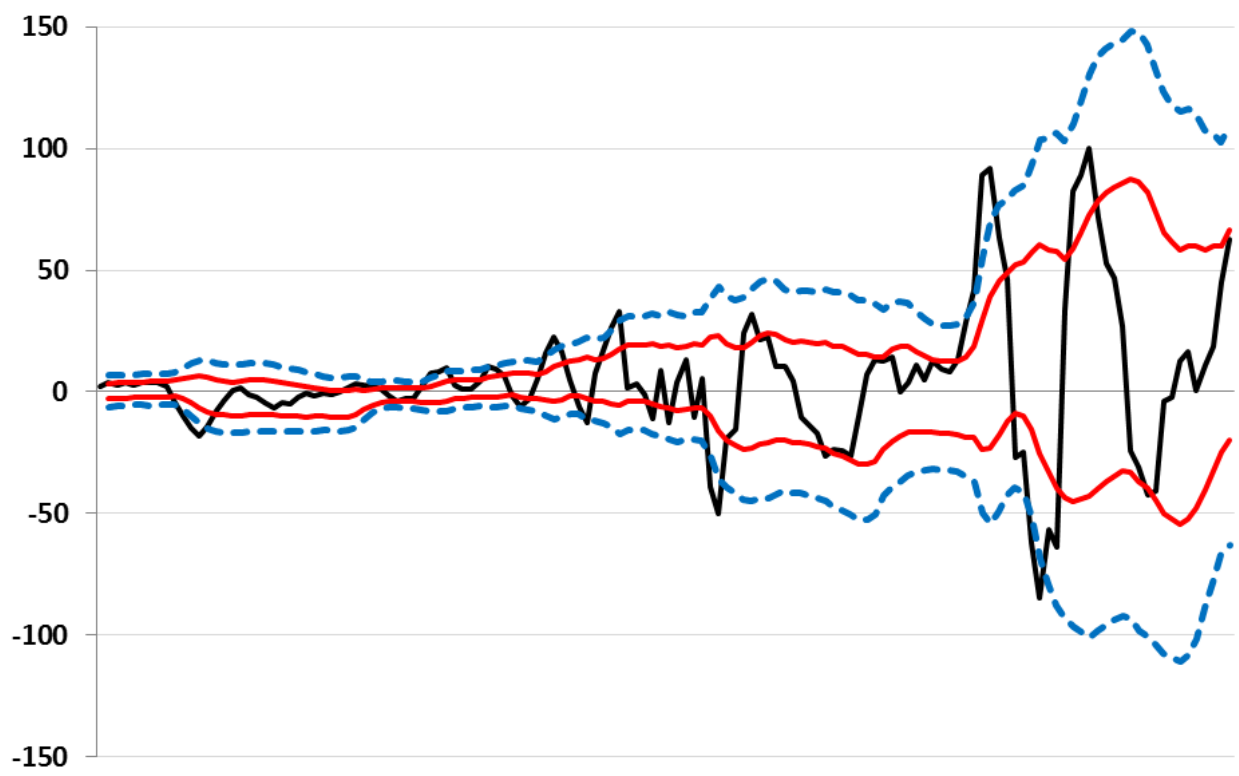

1980q3 1983q3 1986q3 1989q3 1992q3 1995q3 1998q3 2001q32004q33 2007q3 2010q3 2013q3

Change in Gross Inflows —— One Standard Deviation - - - Two Standard Deviation

Notes: Values are in US\$ million. Change in gross capital inflows refer to the year-on-year difference of four quarter cumulative gross inflows. Data taken from Balance of Payments Statistics, International Monetary Fund. 
Figure 3: Frequency of Extreme Episodes
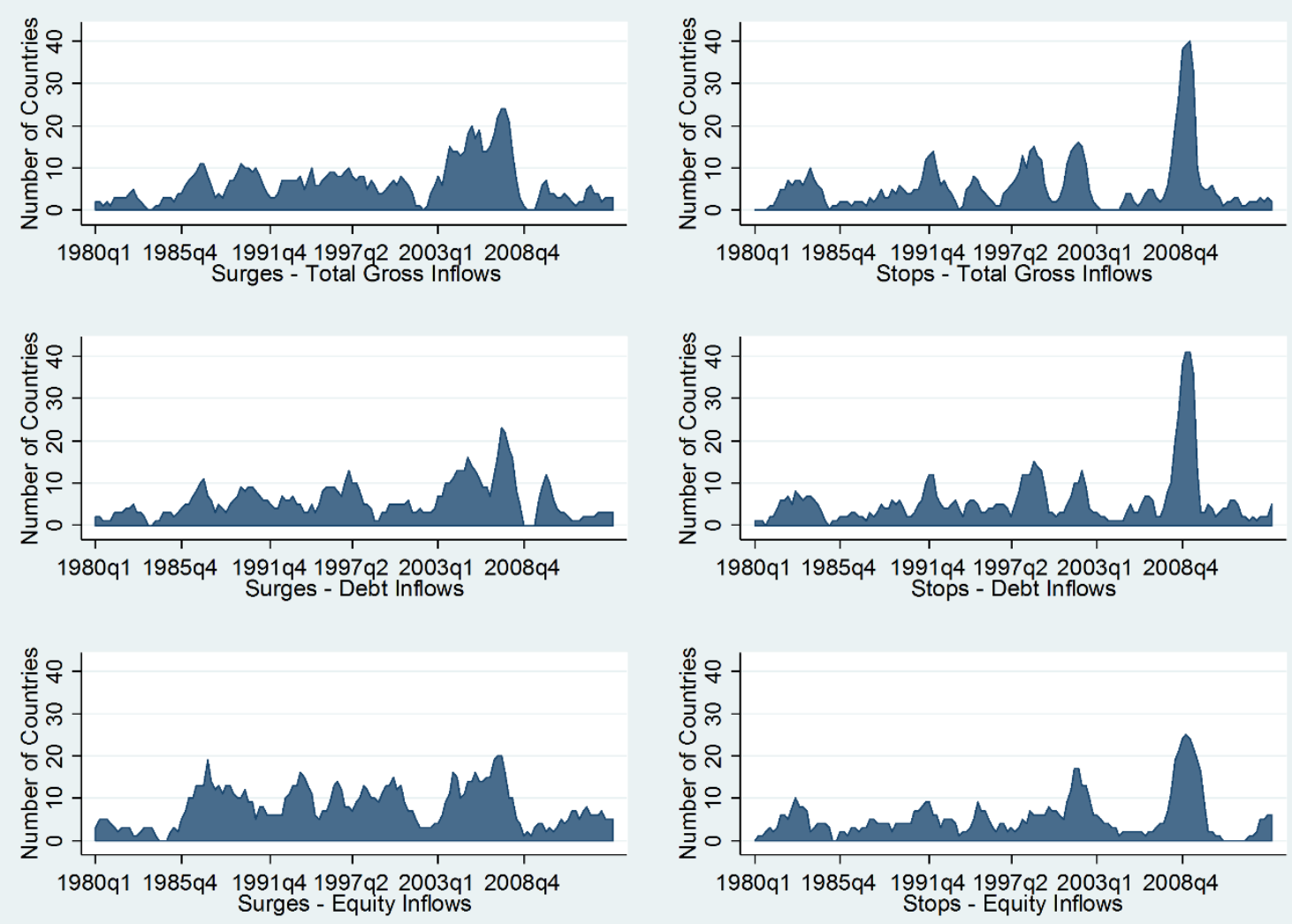

Notes: Values refer to the number of countries experiencing an episode type for a given quarter. Episodes of gross capital inflows are derived following the method of Forbes and Warnock (2012a). 
Figure 4: Transitional Likelihood and State-Dependence Variables
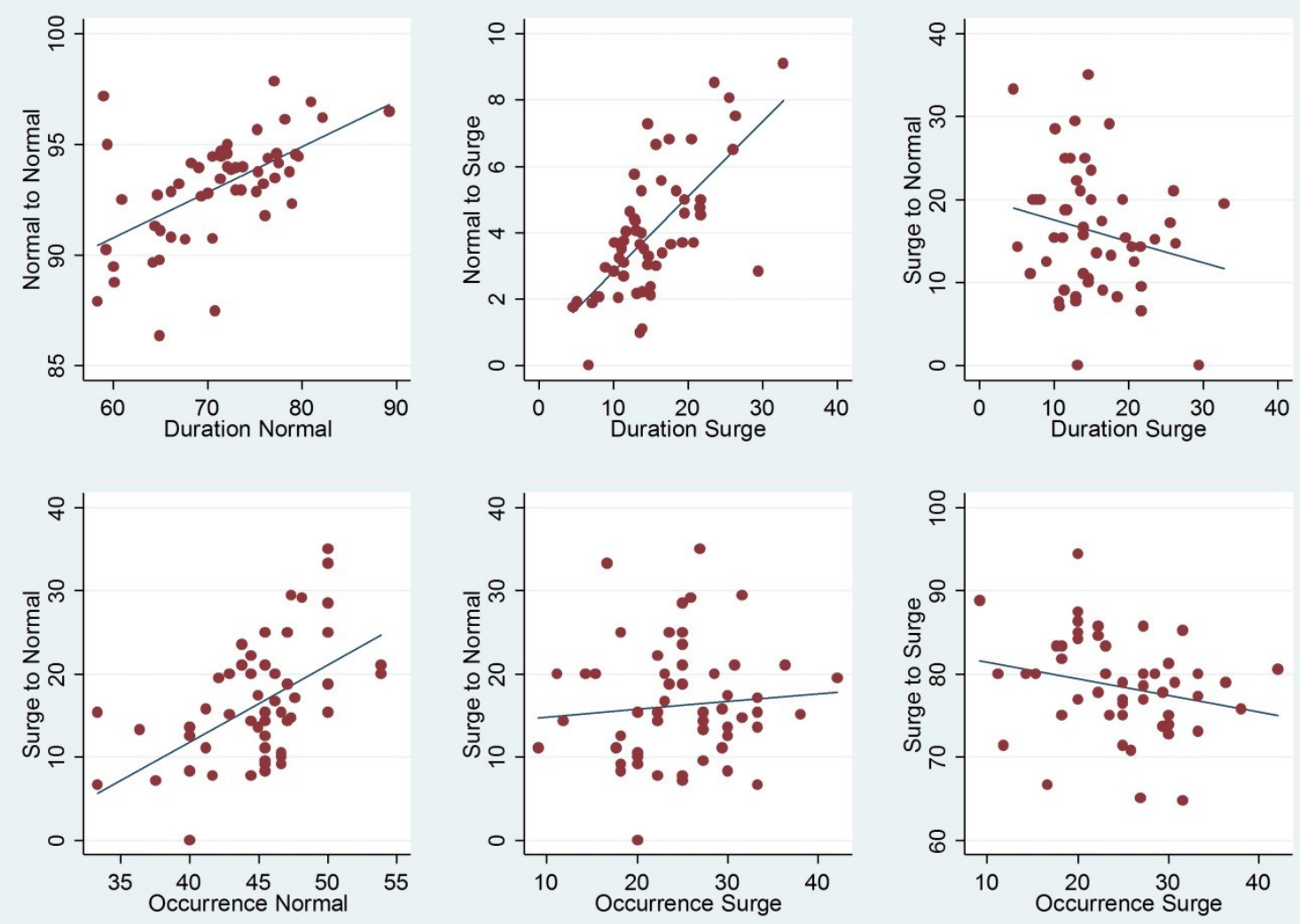

Notes: Values in the $y$-axis refer to the transitional likelihood of moving between episodes. Duration in the $x$-axis refers to the percentage of total number of periods or quarters in a given episode type divided by total periods for each country. Occurrence in the $x$-axis pertains to the percentage of total number of an episode type divided by the total number of episodes regardless of type. 
Table 1: Summary Statistics of Transitional Likelihood

\begin{tabular}{|c|c|c|c|c|c|c|c|c|c|c|c|c|}
\hline Transitions & Obs & Mean & Std. Dev. & CoV & Obs & Mean & Std. Dev. & CoV & Obs & Mean & Std. Dev. & CoV \\
\hline & \multicolumn{4}{|c|}{ Full Sample } & \multicolumn{4}{|c|}{ Advanced } & \multicolumn{4}{|c|}{ Emerging } \\
\hline \multicolumn{13}{|c|}{ Total Gross Inflows } \\
\hline Normal to Normal & 55 & 93.02 & 2.43 & 0.03 & 20 & 91.88 & 2.48 & 0.03 & 35 & 93.68 & 2.17 & 0.02 \\
\hline Normal to Surge & 55 & 4.02 & 1.97 & 0.49 & 20 & 4.79 & 2.16 & 0.45 & 35 & 3.58 & 1.74 & 0.49 \\
\hline Normal to Stop & 55 & 2.96 & 1.54 & 0.52 & 20 & 3.34 & 1.32 & 0.39 & 35 & 2.74 & 1.64 & 0.60 \\
\hline Surge to Normal & 55 & 16.19 & 7.40 & 0.46 & 20 & 17.97 & 6.01 & 0.33 & 35 & 15.18 & 8.00 & 0.53 \\
\hline Surge to Surge & 55 & 78.49 & 5.86 & 0.07 & 20 & 76.54 & 4.90 & 0.06 & 35 & 79.61 & 6.13 & 0.08 \\
\hline Surge to Stop & 55 & 5.31 & 5.53 & 1.04 & 20 & 5.49 & 5.12 & 0.93 & 35 & 5.21 & 5.82 & 1.12 \\
\hline Stop to Normal & 55 & 19.12 & 5.49 & 0.29 & 20 & 18.53 & 5.04 & 0.27 & 35 & 19.46 & 5.78 & 0.30 \\
\hline Stop to Surge & 55 & 2.65 & 4.43 & 1.67 & 20 & 2.23 & 3.57 & 1.60 & 35 & 2.89 & 4.89 & 1.69 \\
\hline Stop to Stop & 55 & 78.22 & 5.69 & 0.07 & 20 & 79.24 & 3.35 & 0.04 & 35 & 77.64 & 6.65 & 0.09 \\
\hline \multicolumn{13}{|c|}{ Debt Inflows } \\
\hline Normal to Normal & 55 & 93.23 & 2.09 & 0.02 & 20 & 92.50 & 2.21 & 0.02 & 35 & 93.64 & 1.93 & 0.02 \\
\hline Normal to Surge & 55 & 3.62 & 1.65 & 0.46 & 20 & 3.94 & 1.34 & 0.34 & 35 & 3.44 & 1.80 & 0.52 \\
\hline Normal to Stop & 55 & 3.15 & 1.47 & 0.47 & 20 & 3.56 & 1.47 & 0.41 & 35 & 2.92 & 1.44 & 0.49 \\
\hline Surge to Normal & 55 & 18.39 & 7.73 & 0.42 & 20 & 19.05 & 6.14 & 0.32 & 35 & 18.01 & 8.56 & 0.48 \\
\hline Surge to Surge & 55 & 76.27 & 5.57 & 0.07 & 20 & 76.32 & 5.28 & 0.07 & 35 & 76.25 & 5.80 & 0.08 \\
\hline Surge to Stop & 55 & 5.34 & 5.86 & 1.10 & 20 & 4.63 & 4.65 & 1.01 & 35 & 5.74 & 6.48 & 1.13 \\
\hline Stop to Normal & 55 & 19.82 & 6.49 & 0.33 & 20 & 18.91 & 3.77 & 0.20 & 35 & 20.35 & 7.63 & 0.38 \\
\hline Stop to Surge & 55 & 3.02 & 3.70 & 1.22 & 20 & 2.88 & 3.59 & 1.25 & 35 & 3.10 & 3.81 & 1.23 \\
\hline Stop to Stop & 55 & 77.15 & 6.01 & 0.08 & 20 & 78.21 & 4.55 & 0.06 & 35 & 76.55 & 6.68 & 0.09 \\
\hline \multicolumn{13}{|c|}{ Equity Inflows } \\
\hline Normal to Normal & 55 & 92.48 & 2.87 & 0.03 & 20 & 93.15 & 1.76 & 0.02 & 35 & 92.10 & 3.30 & 0.04 \\
\hline Normal to Surge & 55 & 4.63 & 2.37 & 0.51 & 20 & 3.72 & 1.02 & 0.27 & 35 & 5.15 & 2.75 & 0.53 \\
\hline Normal to Stop & 55 & 2.89 & 1.59 & 0.55 & 20 & 3.13 & 1.64 & 0.52 & 35 & 2.75 & 1.57 & 0.57 \\
\hline Surge to Normal & 54 & 14.78 & 5.88 & 0.40 & 20 & 15.31 & 5.11 & 0.33 & 34 & 14.47 & 6.35 & 0.44 \\
\hline Surge to Surge & 54 & 80.34 & 5.61 & 0.07 & 20 & 80.29 & 4.94 & 0.06 & 34 & 80.37 & 6.04 & 0.08 \\
\hline Surge to Stop & 54 & 4.88 & 5.23 & 1.07 & 20 & 4.40 & 5.60 & 1.27 & 34 & 5.16 & 5.06 & 0.98 \\
\hline Stop to Normal & 55 & 19.49 & 5.56 & 0.29 & 20 & 20.70 & 5.23 & 0.25 & 35 & 18.80 & 5.70 & 0.30 \\
\hline Stop to Surge & 55 & 2.73 & 4.34 & 1.59 & 20 & 2.94 & 3.47 & 1.18 & 35 & 2.61 & 4.81 & 1.84 \\
\hline Stop to Stop & 55 & 77.78 & 5.58 & 0.07 & 20 & 76.35 & 5.53 & 0.07 & 35 & 78.59 & 5.53 & 0.07 \\
\hline
\end{tabular}

Notes: Values are based on Tables A7 to A9 in Appendix 4. Countries are classified into advanced and emerging countries based on average per capita real GDP at US\$2005, where the cut-off is US\$15,000. The list of countries for each group is shown in Table A5 in Appendix 2. Std. Dev. = standard deviation. CoV = coefficient of variation. 
Table 2: Summary Statistics of State-Dependence Variables

\begin{tabular}{|c|c|c|c|c|c|c|c|c|c|c|c|c|}
\hline State Variables & Obs & Mean & Std. Dev. & CoV & Obs & Mean & Std. Dev. & CoV & Obs & Mean & Std. Dev. & CoV \\
\hline & \multicolumn{4}{|c|}{ Full Sample } & \multicolumn{4}{|c|}{ Advanced } & \multicolumn{4}{|c|}{ Emerging } \\
\hline \multicolumn{13}{|c|}{ Total Gross Inflows } \\
\hline Duration Normal & 55 & 70.983 & 6.768 & 0.10 & 20 & 69.289 & 6.013 & 0.09 & 35 & 71.952 & 7.063 & 0.10 \\
\hline Duration Surge & 55 & 15.300 & 5.928 & 0.39 & 20 & 15.486 & 5.982 & 0.39 & 35 & 15.194 & 5.982 & 0.39 \\
\hline Duration Stop & 55 & 13.717 & 3.842 & 0.28 & 20 & 15.225 & 3.434 & 0.23 & 35 & 12.854 & 3.841 & 0.30 \\
\hline Occurrence Normal & 55 & 44.711 & 4.233 & 0.09 & 20 & 46.219 & 4.818 & 0.10 & 35 & 43.850 & 3.660 & 0.08 \\
\hline Occurrence Surge & 55 & 24.708 & 6.795 & 0.28 & 20 & 26.657 & 7.225 & 0.27 & 35 & 23.594 & 6.376 & 0.27 \\
\hline Occurrence Stop & 55 & 23.506 & 5.887 & 0.25 & 20 & 23.807 & 5.287 & 0.22 & 35 & 23.334 & 6.272 & 0.27 \\
\hline \multicolumn{13}{|c|}{ Debt Inflows } \\
\hline Duration Normal & 55 & 72.961 & 6.103 & 0.08 & 20 & 71.289 & 5.443 & 0.08 & 35 & 73.916 & 6.326 & 0.09 \\
\hline Duration Surge & 55 & 13.471 & 4.947 & 0.37 & 20 & 14.153 & 4.689 & 0.33 & 35 & 13.081 & 5.115 & 0.39 \\
\hline Duration Stop & 55 & 13.568 & 4.105 & 0.30 & 20 & 14.558 & 2.896 & 0.20 & 35 & 13.003 & 4.601 & 0.35 \\
\hline Occurrence Normal & 55 & 44.682 & 4.961 & 0.11 & 20 & 46.324 & 4.665 & 0.10 & 35 & 43.743 & 4.943 & 0.11 \\
\hline Occurrence Surge & 55 & 24.214 & 5.998 & 0.25 & 20 & 25.371 & 5.370 & 0.21 & 35 & 23.554 & 6.308 & 0.27 \\
\hline Occurrence Stop & 55 & 24.281 & 7.032 & 0.29 & 20 & 24.785 & 5.250 & 0.21 & 35 & 23.993 & 7.931 & 0.33 \\
\hline \multicolumn{13}{|c|}{ Equity Inflows } \\
\hline Duration Normal & 55 & 69.835 & 7.142 & 0.10 & 20 & 71.757 & 4.884 & 0.07 & 35 & 68.738 & 8.017 & 0.12 \\
\hline Duration Surge & 54 & 18.256 & 5.461 & 0.30 & 20 & 16.026 & 4.253 & 0.27 & 34 & 19.568 & 5.718 & 0.29 \\
\hline Duration Stop & 55 & 12.240 & 4.099 & 0.33 & 20 & 12.217 & 2.702 & 0.22 & 35 & 12.253 & 4.754 & 0.39 \\
\hline Occurrence Normal & 55 & 44.800 & 3.953 & 0.09 & 20 & 45.708 & 3.579 & 0.08 & 35 & 44.282 & 4.112 & 0.09 \\
\hline Occurrence Surge & 54 & 26.982 & 5.493 & 0.20 & 20 & 26.169 & 5.047 & 0.19 & 34 & 27.460 & 5.758 & 0.21 \\
\hline Occurrence Stop & 55 & 21.807 & 6.100 & 0.28 & 20 & 24.256 & 4.275 & 0.18 & 35 & 20.409 & 6.584 & 0.32 \\
\hline
\end{tabular}

Notes: Values based on Tables A10 to A12 in Appendix 4. Countries are classified into advanced and emerging countries based on average per capita real GDP at US\$2005, where the cut-off is US\$15,000. The list of countries for each group is shown in Table A5 in Appendix 2. Dev. $=$ standard deviation. $\mathrm{CoV}=$ coefficient of variation. 
Table 3: Summary Statistics of Domestic Factors

\begin{tabular}{l|ccccc|c|c}
\hline & \multicolumn{5}{|c|}{ Full Sample } & Advanced & Emerging \\
Domestic Factors & Obs & Mean & Std. Dev. & Min & Max & Mean & Mean \\
\hline Output Volatility & 55 & 3.57 & 1.81 & 1.44 & 9.57 & 2.30 & 4.29 \\
Per Capita Income & 55 & 90.24 & 13.18 & 60.11 & 108.94 & 103.22 & 82.83 \\
Domestic Credit & 55 & 62.63 & 37.03 & 17.87 & 182.11 & 92.99 & 45.27 \\
Market Capitalization & 55 & 45.14 & 36.26 & 3.17 & 163.25 & 57.97 & 37.82 \\
Trade Openness & 55 & 61.28 & 41.75 & 17.23 & 288.32 & 48.76 & 68.43 \\
Financial Openness & 55 & 207.40 & 218.15 & 39.22 & $1,231.99$ & 317.94 & 144.24 \\
Capital Openness & 55 & 60.21 & 29.09 & 10.35 & 100.00 & 83.47 & 46.91 \\
Net Foreign Assets & 55 & -27.03 & 36.88 & -147.39 & 117.81 & -25.87 & -27.69 \\
Foreign Reserves & 55 & 12.22 & 12.14 & 0.73 & 78.63 & 5.90 & 15.84 \\
\hline
\end{tabular}

Notes: Output volatility refers to the standard deviation of annual output growth. Per capital income is in log multiplied by 10. Capital openness refers to the Chinn-Ito standardized index (2006) scaled to 100. Domestic credit, market capitalization, trade openness, financial openness, net foreign assets, and foreign reserves are in percent of nominal GDP. Refer to Appendix 5 for data sources. 
Table 4: Transitional Likelihood: State-Dependence Variables, Total Gross Inflows

\begin{tabular}{|c|c|c|c|c|c|c|c|c|c|}
\hline VARIABLES & $\begin{array}{c}(1) \\
\text { Normal to } \\
\text { Normal } \\
\end{array}$ & $\begin{array}{c}(2) \\
\text { Normal to } \\
\text { Surge }\end{array}$ & $\begin{array}{c}\text { (3) } \\
\text { Normal to } \\
\text { Stop }\end{array}$ & $\begin{array}{c}\text { (4) } \\
\text { Surge to } \\
\text { Normal }\end{array}$ & $\begin{array}{c}\text { (5) } \\
\text { Surge to } \\
\text { Surge }\end{array}$ & $\begin{array}{c}\text { (6) } \\
\text { Surge to } \\
\text { Stop }\end{array}$ & $\begin{array}{c}\text { (7) } \\
\text { Stop to } \\
\text { Normal }\end{array}$ & $\begin{array}{c}\text { (8) } \\
\text { Stop to } \\
\text { Surge }\end{array}$ & $\begin{array}{c}\text { (9) } \\
\text { Stop to } \\
\text { Stop }\end{array}$ \\
\hline Duration Normal & $\begin{array}{c}0.275^{* * *} \\
(0.039)\end{array}$ & $\begin{array}{c}-0.163^{* * *} \\
(0.035)\end{array}$ & $\begin{array}{c}-0.109^{* *} \\
(0.040)\end{array}$ & $\begin{array}{l}-0.051 \\
(0.260)\end{array}$ & & & $\begin{array}{l}-0.048 \\
(0.131)\end{array}$ & & \\
\hline Duration Surge & & $\begin{array}{l}-0.024 \\
(0.048)\end{array}$ & & $\begin{array}{c}-0.511^{*} \\
(0.249)\end{array}$ & $\begin{array}{c}0.902^{* * *} \\
(0.102)\end{array}$ & $\begin{array}{l}-0.255 \\
(0.171)\end{array}$ & & $\begin{array}{c}0.188 \\
(0.107)\end{array}$ & \\
\hline Duration Stop & & & $\begin{array}{l}-0.063 \\
(0.086)\end{array}$ & & & $\begin{array}{c}0.183 \\
(0.229)\end{array}$ & $\begin{array}{l}-0.597 \\
(0.301)\end{array}$ & $\begin{array}{c}-0.631^{* *} \\
(0.202)\end{array}$ & $\begin{array}{c}0.913^{* * *} \\
(0.234)\end{array}$ \\
\hline Occurrence Normal & $\begin{array}{c}-0.295^{* * *} \\
(0.060)\end{array}$ & $\begin{array}{c}0.162^{* * *} \\
(0.038)\end{array}$ & $\begin{array}{c}0.228^{* * *} \\
(0.042)\end{array}$ & $\begin{array}{c}0.993 * * * \\
(0.218)\end{array}$ & & & $\begin{array}{c}0.498^{* *} \\
(0.163)\end{array}$ & & \\
\hline Occurrence Surge & & $\begin{array}{c}0.172^{* * *} \\
(0.029)\end{array}$ & & $\begin{array}{c}0.532 * * * \\
(0.140)\end{array}$ & $\begin{array}{c}-0.719 * * * \\
(0.102)\end{array}$ & $\begin{array}{c}0.493^{* *} \\
(0.176)\end{array}$ & & $\begin{array}{c}0.432^{* * *} \\
(0.105)\end{array}$ & \\
\hline Occurrence Stop & & & $\begin{array}{c}0.184^{* * *} \\
(0.043)\end{array}$ & & & $\begin{array}{c}0.389 \\
(0.201)\end{array}$ & $\begin{array}{l}0.419^{*} \\
(0.208)\end{array}$ & $\begin{array}{c}0.755^{* * *} \\
(0.172)\end{array}$ & $\begin{array}{c}-0.553^{* * *} \\
(0.137)\end{array}$ \\
\hline Constant & $\begin{array}{c}86.675^{* * *} \\
(3.634)\end{array}$ & $\begin{array}{c}4.453 \\
(2.731)\end{array}$ & $\begin{array}{l}-2.971 \\
(3.429)\end{array}$ & $\begin{array}{l}-29.906 \\
(21.058)\end{array}$ & $\begin{array}{c}82.460 * * * \\
(2.216)\end{array}$ & $\begin{array}{c}-14.621^{*} \\
(6.201)\end{array}$ & $\begin{array}{c}-1.383 \\
(11.257)\end{array}$ & $\begin{array}{c}-19.974^{* * *} \\
(4.936)\end{array}$ & $\begin{array}{c}78.715^{* * *} \\
(2.609)\end{array}$ \\
\hline Observations & 55 & 55 & 3 & 55 & 55 & 55 & 55 & 55 & 55 \\
\hline R-squared & 0.561 & 0.743 & 0.510 & 0.417 & 0.525 & 0.240 & 0.272 & 0.388 & 0.299 \\
\hline RSS & 139.480 & 53.835 & 63.093 & 1725.582 & 878.838 & 1254.890 & 1186.171 & 649.839 & 1226.847 \\
\hline
\end{tabular}

Notes: Dependent variables are transitional likelihoods for total gross inflows in percent as presented in Table A7 in Appendix 4. Duration and occurrence are presented in Table A10 in Appendix 4. RSS pertains to the residual sum of squares. Robust standard errors are in parenthesis. ${ }^{* * *} p<0.01,{ }^{* *} p<0.05,{ }^{*} p<0.1$. 
Table 5: State-Dependence Variables on Domestic Factors, Total Gross Inflows

\begin{tabular}{|c|c|c|c|c|c|c|}
\hline VARIABLES & $\begin{array}{c}\text { (1) } \\
\text { Duration } \\
\text { Normal } \\
\end{array}$ & $\begin{array}{c}\text { (2) } \\
\text { Duration } \\
\text { Surge } \\
\end{array}$ & $\begin{array}{c}\text { (3) } \\
\text { Duration } \\
\text { Stop } \\
\end{array}$ & $\begin{array}{c}\text { (4) } \\
\text { Occurrence } \\
\text { Nornal }\end{array}$ & $\begin{array}{c}\text { (5) } \\
\text { Occurrence } \\
\text { Surge }\end{array}$ & $\begin{array}{c}\text { (6) } \\
\text { Occurrence } \\
\text { Stop } \\
\end{array}$ \\
\hline Output Volatility & $\begin{array}{l}-0.442 \\
(0.722)\end{array}$ & $\begin{array}{c}0.625 \\
(0.655)\end{array}$ & $\begin{array}{l}-0.183 \\
(0.282)\end{array}$ & $\begin{array}{c}-0.818^{* *} \\
(0.315)\end{array}$ & $\begin{array}{l}-0.743 \\
(0.562)\end{array}$ & $\begin{array}{c}0.091 \\
(0.582)\end{array}$ \\
\hline Per Capita Income & $\begin{array}{c}0.048 \\
(0.120)\end{array}$ & $\begin{array}{l}-0.126 \\
(0.097)\end{array}$ & $\begin{array}{c}0.079 \\
(0.060)\end{array}$ & $\begin{array}{c}0.036 \\
(0.077)\end{array}$ & $\begin{array}{l}-0.137 \\
(0.096)\end{array}$ & $\begin{array}{c}0.100 \\
(0.102)\end{array}$ \\
\hline Domestic Credit & $\begin{array}{l}-0.047 \\
(0.040)\end{array}$ & $\begin{array}{c}0.050 \\
(0.033)\end{array}$ & $\begin{array}{l}-0.003 \\
(0.022)\end{array}$ & $\begin{array}{c}0.016 \\
(0.020)\end{array}$ & $\begin{array}{c}0.006 \\
(0.036)\end{array}$ & $\begin{array}{l}-0.027 \\
(0.030)\end{array}$ \\
\hline Market Capitalization & $\begin{array}{c}0.022 \\
(0.036)\end{array}$ & $\begin{array}{l}-0.017 \\
(0.029)\end{array}$ & $\begin{array}{l}-0.005 \\
(0.023)\end{array}$ & $\begin{array}{l}-0.019 \\
(0.020)\end{array}$ & $\begin{array}{c}0.019 \\
(0.031)\end{array}$ & $\begin{array}{c}0.010 \\
(0.028)\end{array}$ \\
\hline Trade Openness & $\begin{array}{l}-0.046 \\
(0.046)\end{array}$ & $\begin{array}{c}0.032 \\
(0.039)\end{array}$ & $\begin{array}{c}0.013 \\
(0.025)\end{array}$ & $\begin{array}{c}0.007 \\
(0.032)\end{array}$ & $\begin{array}{l}-0.007 \\
(0.049)\end{array}$ & $\begin{array}{l}-0.040 \\
(0.036)\end{array}$ \\
\hline Financial Openness & $\begin{array}{l}-0.004 \\
(0.006)\end{array}$ & $\begin{array}{c}0.010 \\
(0.006)\end{array}$ & $\begin{array}{c}-0.005^{*} \\
(0.003)\end{array}$ & $\begin{array}{l}-0.001 \\
(0.004)\end{array}$ & $\begin{array}{c}0.011 \\
(0.007)\end{array}$ & $\begin{array}{l}-0.006 \\
(0.006)\end{array}$ \\
\hline Capital Openness & $\begin{array}{c}0.020 \\
(0.044)\end{array}$ & $\begin{array}{l}-0.048 \\
(0.032)\end{array}$ & $\begin{array}{c}0.028 \\
(0.025)\end{array}$ & $\begin{array}{l}-0.004 \\
(0.029)\end{array}$ & $\begin{array}{l}-0.006 \\
(0.030)\end{array}$ & $\begin{array}{l}0.050^{*} \\
(0.027)\end{array}$ \\
\hline Net Foreign Assets & $\begin{array}{c}0.011 \\
(0.026)\end{array}$ & $\begin{array}{l}-0.004 \\
(0.023)\end{array}$ & $\begin{array}{l}-0.007 \\
(0.013)\end{array}$ & $\begin{array}{l}-0.000 \\
(0.018)\end{array}$ & $\begin{array}{c}0.015 \\
(0.026)\end{array}$ & $\begin{array}{l}-0.012 \\
(0.022)\end{array}$ \\
\hline Foreign Reserves & $\begin{array}{l}0.257^{*} \\
(0.146)\end{array}$ & $\begin{array}{l}-0.222 \\
(0.136)\end{array}$ & $\begin{array}{l}-0.035 \\
(0.070)\end{array}$ & $\begin{array}{l}-0.020 \\
(0.101)\end{array}$ & $\begin{array}{l}-0.107 \\
(0.160)\end{array}$ & $\begin{array}{c}0.145 \\
(0.113)\end{array}$ \\
\hline Constant & $\begin{array}{c}69.835^{* * *} \\
(10.170)\end{array}$ & $\begin{array}{c}23.619 * * * \\
(8.352)\end{array}$ & $\begin{array}{c}6.546 \\
(4.421)\end{array}$ & $\begin{array}{c}44.576^{* * *} \\
(6.314)\end{array}$ & $\begin{array}{c}38.602^{* * *} \\
(7.489)\end{array}$ & $\begin{array}{l}13.934 \\
(9.187)\end{array}$ \\
\hline Observations & 55 & 55 & 55 & 55 & 55 & 55 \\
\hline R-squared & 0.111 & 0.197 & 0.191 & 0.182 & 0.183 & 0.107 \\
\hline
\end{tabular}


Table 6: State-Dependence Variables on Domestic Factors, Debt Inflows

\begin{tabular}{|c|c|c|c|c|c|c|}
\hline VARIABLES & $\begin{array}{c}\text { (1) } \\
\text { Duration } \\
\text { Normal } \\
\end{array}$ & $\begin{array}{c}\text { (2) } \\
\text { Duration } \\
\text { Surge }\end{array}$ & $\begin{array}{c}\text { (3) } \\
\text { Duration } \\
\text { Stop }\end{array}$ & $\begin{array}{c}\text { (4) } \\
\text { Occurrence } \\
\text { Nornal }\end{array}$ & $\begin{array}{c}\text { (5) } \\
\text { Occurrence } \\
\text { Surge }\end{array}$ & $\begin{array}{c}\text { (6) } \\
\text { Occurrence } \\
\text { Stop } \\
\end{array}$ \\
\hline Output Volatility & $\begin{array}{l}-0.076 \\
(0.624)\end{array}$ & $\begin{array}{c}0.383 \\
(0.558)\end{array}$ & $\begin{array}{l}-0.307 \\
(0.408)\end{array}$ & $\begin{array}{l}-0.742 \\
(0.651)\end{array}$ & $\begin{array}{c}0.337 \\
(0.621)\end{array}$ & $\begin{array}{l}-0.587 \\
(0.762)\end{array}$ \\
\hline Per Capita Income & $\begin{array}{l}-0.071 \\
(0.119)\end{array}$ & $\begin{array}{l}-0.021 \\
(0.095)\end{array}$ & $\begin{array}{c}0.092 \\
(0.058)\end{array}$ & $\begin{array}{l}-0.045 \\
(0.088)\end{array}$ & $\begin{array}{l}-0.117 \\
(0.097)\end{array}$ & $\begin{array}{c}0.136 \\
(0.114)\end{array}$ \\
\hline Domestic Credit & $\begin{array}{l}-0.059 \\
(0.049)\end{array}$ & $\begin{array}{l}0.060 * \\
(0.032)\end{array}$ & $\begin{array}{l}-0.001 \\
(0.031)\end{array}$ & $\begin{array}{c}0.058 \\
(0.037)\end{array}$ & $\begin{array}{c}0.020 \\
(0.035)\end{array}$ & $\begin{array}{l}-0.053 \\
(0.053)\end{array}$ \\
\hline Market Capitalization & $\begin{array}{c}0.038 \\
(0.043)\end{array}$ & $\begin{array}{l}-0.027 \\
(0.030)\end{array}$ & $\begin{array}{l}-0.011 \\
(0.024)\end{array}$ & $\begin{array}{c}-0.044^{*} \\
(0.022)\end{array}$ & $\begin{array}{l}0.043^{*} \\
(0.024)\end{array}$ & $\begin{array}{c}0.001 \\
(0.034)\end{array}$ \\
\hline Trade Openness & $\begin{array}{l}-0.030 \\
(0.043)\end{array}$ & $\begin{array}{c}0.017 \\
(0.036)\end{array}$ & $\begin{array}{c}0.013 \\
(0.037)\end{array}$ & $\begin{array}{c}0.032 \\
(0.037)\end{array}$ & $\begin{array}{c}0.037 \\
(0.040)\end{array}$ & $\begin{array}{l}-0.091 \\
(0.056)\end{array}$ \\
\hline Financial Openness & $\begin{array}{l}-0.000 \\
(0.005)\end{array}$ & $\begin{array}{c}0.004 \\
(0.005)\end{array}$ & $\begin{array}{l}-0.004 \\
(0.003)\end{array}$ & $\begin{array}{c}0.002 \\
(0.004)\end{array}$ & $\begin{array}{c}0.004 \\
(0.006)\end{array}$ & $\begin{array}{l}-0.002 \\
(0.006)\end{array}$ \\
\hline Capital Openness & $\begin{array}{c}0.049 \\
(0.044)\end{array}$ & $\begin{array}{l}-0.041 \\
(0.033)\end{array}$ & $\begin{array}{l}-0.008 \\
(0.028)\end{array}$ & $\begin{array}{l}-0.011 \\
(0.032)\end{array}$ & $\begin{array}{c}0.008 \\
(0.024)\end{array}$ & $\begin{array}{c}0.025 \\
(0.032)\end{array}$ \\
\hline Net Foreign Assets & $\begin{array}{l}-0.008 \\
(0.023)\end{array}$ & $\begin{array}{l}-0.001 \\
(0.018)\end{array}$ & $\begin{array}{c}0.009 \\
(0.014)\end{array}$ & $\begin{array}{l}-0.001 \\
(0.021)\end{array}$ & $\begin{array}{c}0.021 \\
(0.023)\end{array}$ & $\begin{array}{l}-0.012 \\
(0.026)\end{array}$ \\
\hline Foreign Reserves & $\begin{array}{c}0.116 \\
(0.132)\end{array}$ & $\begin{array}{l}-0.103 \\
(0.101)\end{array}$ & $\begin{array}{l}-0.013 \\
(0.091)\end{array}$ & $\begin{array}{l}-0.073 \\
(0.093)\end{array}$ & $\begin{array}{c}-0.289^{* * *} \\
(0.087)\end{array}$ & $\begin{array}{c}0.337^{* * *} \\
(0.112)\end{array}$ \\
\hline Constant & $\begin{array}{c}78.922^{* * *} \\
(9.226)\end{array}$ & $\begin{array}{l}13.239 * \\
(7.670)\end{array}$ & $\begin{array}{l}7.839 * \\
(4.157)\end{array}$ & $\begin{array}{c}48.948^{* * *} \\
(6.634)\end{array}$ & $\begin{array}{c}30.951^{* * *} \\
(8.433)\end{array}$ & $\begin{array}{c}17.445^{* *} \\
(8.355)\end{array}$ \\
\hline Observations & 55 & 55 & 55 & 55 & 55 & 55 \\
\hline R-squared & 0.098 & 0.106 & 0.093 & 0.169 & 0.169 & 0.125 \\
\hline
\end{tabular}


Table 7: State-Dependence Variables on Domestic Factors, Equity Inflows

\begin{tabular}{|c|c|c|c|c|c|c|}
\hline VARIABLES & $\begin{array}{c}(1) \\
\text { Duration } \\
\text { Normal } \\
\end{array}$ & $\begin{array}{c}(2) \\
\text { Duration } \\
\text { Surge } \\
\end{array}$ & $\begin{array}{c}(3) \\
\text { Duration } \\
\text { Stop } \\
\end{array}$ & $\begin{array}{c}\text { (4) } \\
\text { Occurrence } \\
\text { Nornal } \\
\end{array}$ & $\begin{array}{c}\text { (5) } \\
\text { Occurrence } \\
\text { Surge }\end{array}$ & $\begin{array}{c}(6) \\
\text { Occurrence } \\
\text { Stop } \\
\end{array}$ \\
\hline Output Volatility & $\begin{array}{c}0.103 \\
(0.819)\end{array}$ & $\begin{array}{l}-0.500 \\
(0.536)\end{array}$ & $\begin{array}{c}0.322 \\
(0.390)\end{array}$ & $\begin{array}{l}-0.099 \\
(0.378)\end{array}$ & $\begin{array}{l}-0.275 \\
(0.481)\end{array}$ & $\begin{array}{l}-0.339 \\
(0.512)\end{array}$ \\
\hline Per Capita Income & $\begin{array}{l}-0.010 \\
(0.124)\end{array}$ & $\begin{array}{l}-0.056 \\
(0.082)\end{array}$ & $\begin{array}{c}0.072 \\
(0.079)\end{array}$ & $\begin{array}{c}0.017 \\
(0.074)\end{array}$ & $\begin{array}{l}-0.121 * \\
(0.071)\end{array}$ & $\begin{array}{c}0.114 \\
(0.109)\end{array}$ \\
\hline Domestic Credit & $\begin{array}{l}-0.022 \\
(0.045)\end{array}$ & $\begin{array}{c}0.034 \\
(0.033)\end{array}$ & $\begin{array}{l}-0.014 \\
(0.022)\end{array}$ & $\begin{array}{c}0.029 \\
(0.021)\end{array}$ & $\begin{array}{c}0.016 \\
(0.035)\end{array}$ & $\begin{array}{l}-0.040 \\
(0.030)\end{array}$ \\
\hline Market Capitalization & $\begin{array}{c}0.031 \\
(0.028)\end{array}$ & $\begin{array}{l}-0.026 \\
(0.022)\end{array}$ & $\begin{array}{l}-0.012 \\
(0.017)\end{array}$ & $\begin{array}{l}-0.025 \\
(0.023)\end{array}$ & $\begin{array}{c}0.019 \\
(0.028)\end{array}$ & $\begin{array}{c}0.015 \\
(0.025)\end{array}$ \\
\hline Trade Openness & $\begin{array}{c}0.037 \\
(0.053)\end{array}$ & $\begin{array}{c}0.021 \\
(0.037)\end{array}$ & $\begin{array}{l}-0.047 \\
(0.029)\end{array}$ & $\begin{array}{c}0.023 \\
(0.026)\end{array}$ & $\begin{array}{c}0.040 \\
(0.051)\end{array}$ & $\begin{array}{l}-0.084 * \\
(0.042)\end{array}$ \\
\hline Financial Openness & $\begin{array}{l}-0.008 \\
(0.006)\end{array}$ & $\begin{array}{l}0.006^{*} \\
(0.003)\end{array}$ & $\begin{array}{c}0.001 \\
(0.004)\end{array}$ & $\begin{array}{c}0.000 \\
(0.003)\end{array}$ & $\begin{array}{l}-0.005 \\
(0.005)\end{array}$ & $\begin{array}{l}0.006^{*} \\
(0.003)\end{array}$ \\
\hline Capital Openness & $\begin{array}{l}0.101^{* *} \\
(0.048)\end{array}$ & $\begin{array}{c}-0.114^{* * *} \\
(0.037)\end{array}$ & $\begin{array}{c}0.024 \\
(0.030)\end{array}$ & $\begin{array}{l}-0.019 \\
(0.030)\end{array}$ & $\begin{array}{c}-0.001 \\
(0.031)\end{array}$ & $\begin{array}{c}0.056 \\
(0.045)\end{array}$ \\
\hline Net Foreign Assets & $\begin{array}{l}-0.003 \\
(0.030)\end{array}$ & $\begin{array}{l}-0.005 \\
(0.022)\end{array}$ & $\begin{array}{c}0.007 \\
(0.016)\end{array}$ & $\begin{array}{l}-0.006 \\
(0.018)\end{array}$ & $\begin{array}{l}-0.001 \\
(0.023)\end{array}$ & $\begin{array}{c}0.012 \\
(0.024)\end{array}$ \\
\hline Foreign Reserves & $\begin{array}{l}-0.064 \\
(0.179)\end{array}$ & $\begin{array}{l}-0.036 \\
(0.120)\end{array}$ & $\begin{array}{c}0.108 \\
(0.094)\end{array}$ & $\begin{array}{l}-0.121 \\
(0.098)\end{array}$ & $\begin{array}{l}-0.094 \\
(0.157)\end{array}$ & $\begin{array}{l}0.196^{*} \\
(0.112)\end{array}$ \\
\hline Constant & $\begin{array}{c}64.371^{* * *} \\
(9.279)\end{array}$ & $\begin{array}{c}28.769 * * * \\
(4.889)\end{array}$ & $\begin{array}{c}6.194 \\
(6.269)\end{array}$ & $\begin{array}{c}43.908^{* * *} \\
(5.682)\end{array}$ & $\begin{array}{c}36.779 * * * \\
(4.827)\end{array}$ & $\begin{array}{l}12.969 \\
(8.005)\end{array}$ \\
\hline Observations & 55 & 54 & 55 & 55 & 54 & 55 \\
\hline R-squared & 0.150 & 0.288 & 0.108 & 0.129 & 0.089 & 0.244 \\
\hline
\end{tabular}

Notes: Dependent variables are the "duration" and "occurrence" of "normal", "surge", and "stop" episodes as shown in Table A12 in Appendix 4. Output volatility refers to the standard deviation of annual output growth. Per capital income is in log multiplied by 10. Capital openness refers to the Chinn-Ito normalized index (2006) multiplied by 100. Domestic credit, market capitalization, trade openness, financial openness, net foreign assets, and foreign reserves are in percent of nominal GDP. Robust standard errors are in parenthesis. ${ }^{* * *} p<0.01,{ }^{* *} p<0.05,{ }^{*} p<0.1$. 
Table 8: State-Dependence Variables on Domestic Factors, Total Gross Inflows (Excluding Ireland and Singapore)

\begin{tabular}{|c|c|c|c|c|c|c|}
\hline VARIABLES & $\begin{array}{c}\mathbf{( 1 )} \\
\text { Duration } \\
\text { Normal } \\
\end{array}$ & $\begin{array}{c}(2) \\
\text { Duration } \\
\text { Surge } \\
\end{array}$ & $\begin{array}{c}\text { (3) } \\
\text { Duration } \\
\text { Stop } \\
\end{array}$ & $\begin{array}{c}\text { (4) } \\
\text { Occurrence } \\
\text { Nornal } \\
\end{array}$ & $\begin{array}{c}\text { (5) } \\
\text { Occurrence } \\
\text { Surge }\end{array}$ & $\begin{array}{c}\text { (6) } \\
\text { Occurrence } \\
\text { Stop }\end{array}$ \\
\hline Output Volatility & $\begin{array}{l}-0.528 \\
(0.735)\end{array}$ & $\begin{array}{c}0.615 \\
(0.686)\end{array}$ & $\begin{array}{l}-0.087 \\
(0.300)\end{array}$ & $\begin{array}{c}-0.889 * * * \\
(0.319)\end{array}$ & $\begin{array}{l}-0.696 \\
(0.597)\end{array}$ & $\begin{array}{c}0.114 \\
(0.620)\end{array}$ \\
\hline Per Capita Income & $\begin{array}{c}0.023 \\
(0.123)\end{array}$ & $\begin{array}{l}-0.098 \\
(0.098)\end{array}$ & $\begin{array}{c}0.075 \\
(0.061)\end{array}$ & $\begin{array}{c}0.026 \\
(0.078)\end{array}$ & $\begin{array}{l}-0.106 \\
(0.096)\end{array}$ & $\begin{array}{c}0.073 \\
(0.102)\end{array}$ \\
\hline Domestic Credit & $\begin{array}{l}-0.060 \\
(0.045)\end{array}$ & $\begin{array}{c}0.055 \\
(0.036)\end{array}$ & $\begin{array}{c}0.005 \\
(0.023)\end{array}$ & $\begin{array}{c}0.007 \\
(0.020)\end{array}$ & $\begin{array}{c}0.016 \\
(0.037)\end{array}$ & $\begin{array}{l}-0.030 \\
(0.030)\end{array}$ \\
\hline Market Capitalization & $\begin{array}{c}0.024 \\
(0.039)\end{array}$ & $\begin{array}{l}-0.010 \\
(0.030)\end{array}$ & $\begin{array}{l}-0.014 \\
(0.024)\end{array}$ & $\begin{array}{l}-0.015 \\
(0.023)\end{array}$ & $\begin{array}{c}0.022 \\
(0.035)\end{array}$ & $\begin{array}{c}0.002 \\
(0.030)\end{array}$ \\
\hline Trade Openness & $\begin{array}{l}-0.047 \\
(0.049)\end{array}$ & $\begin{array}{c}0.041 \\
(0.038)\end{array}$ & $\begin{array}{c}0.005 \\
(0.029)\end{array}$ & $\begin{array}{c}0.009 \\
(0.036)\end{array}$ & $\begin{array}{c}-0.001 \\
(0.052)\end{array}$ & $\begin{array}{l}-0.049 \\
(0.036)\end{array}$ \\
\hline Financial Openness & $\begin{array}{c}0.010 \\
(0.008)\end{array}$ & $\begin{array}{l}-0.006 \\
(0.007)\end{array}$ & $\begin{array}{l}-0.004 \\
(0.005)\end{array}$ & $\begin{array}{c}0.005 \\
(0.008)\end{array}$ & $\begin{array}{l}-0.006 \\
(0.011)\end{array}$ & $\begin{array}{c}0.008 \\
(0.005)\end{array}$ \\
\hline Capital Openness & $\begin{array}{c}0.008 \\
(0.048)\end{array}$ & $\begin{array}{c}-0.034 \\
(0.034)\end{array}$ & $\begin{array}{c}0.025 \\
(0.026)\end{array}$ & $\begin{array}{l}-0.008 \\
(0.030)\end{array}$ & $\begin{array}{c}0.010 \\
(0.034)\end{array}$ & $\begin{array}{c}0.036 \\
(0.028)\end{array}$ \\
\hline Net Foreign Assets & $\begin{array}{c}0.021 \\
(0.026)\end{array}$ & $\begin{array}{l}-0.009 \\
(0.026)\end{array}$ & $\begin{array}{l}-0.012 \\
(0.012)\end{array}$ & $\begin{array}{c}0.006 \\
(0.019)\end{array}$ & $\begin{array}{c}0.007 \\
(0.025)\end{array}$ & $\begin{array}{l}-0.009 \\
(0.022)\end{array}$ \\
\hline Foreign Reserves & $\begin{array}{l}0.328 * \\
(0.163)\end{array}$ & $\begin{array}{c}-0.262 * \\
(0.137)\end{array}$ & $\begin{array}{l}-0.066 \\
(0.069)\end{array}$ & $\begin{array}{c}0.022 \\
(0.088)\end{array}$ & $\begin{array}{l}-0.172 \\
(0.142)\end{array}$ & $\begin{array}{c}0.177 \\
(0.105)\end{array}$ \\
\hline Constant & $\begin{array}{c}\text { 71.033*** } \\
(10.481)\end{array}$ & $\begin{array}{c}21.927^{* *} \\
(8.453)\end{array}$ & $\begin{array}{c}7.040 \\
(4.612)\end{array}$ & $\begin{array}{c}44.934^{* * *} \\
(6.437)\end{array}$ & $\begin{array}{c}36.930 * * * \\
(7.267)\end{array}$ & $\begin{array}{l}15.580^{*} \\
(9.112)\end{array}$ \\
\hline Observations & 53 & 53 & 53 & 53 & 53 & 53 \\
\hline R-squared & 0.117 & 0.147 & 0.180 & 0.195 & 0.161 & 0.099 \\
\hline
\end{tabular}


Table 9: State-Dependence Variables on Domestic Factors, Debt Inflows (Excluding Ireland and Singapore)

\begin{tabular}{|c|c|c|c|c|c|c|}
\hline VARIABLES & $\begin{array}{c}\mathbf{( 1 )} \\
\text { Duration } \\
\text { Normal } \\
\end{array}$ & $\begin{array}{c}(2) \\
\text { Duration } \\
\text { Surge } \\
\end{array}$ & $\begin{array}{c}\text { (3) } \\
\text { Duration } \\
\text { Stop } \\
\end{array}$ & \begin{tabular}{|c|}
$(4)$ \\
Occurrence \\
Nornal \\
\end{tabular} & $\begin{array}{c}\text { (5) } \\
\text { Occurrence } \\
\text { Surge }\end{array}$ & $\begin{array}{c}(6) \\
\text { Occurrence } \\
\text { Stop }\end{array}$ \\
\hline Output Volatility & $\begin{array}{c}-0.134 \\
(0.622)\end{array}$ & $\begin{array}{c}0.376 \\
(0.574)\end{array}$ & $\begin{array}{c}-0.242 \\
(0.425)\end{array}$ & $\begin{array}{c}-0.578 \\
(0.640)\end{array}$ & $\begin{array}{c}0.194 \\
(0.654)\end{array}$ & $\begin{array}{l}-0.517 \\
(0.821)\end{array}$ \\
\hline Per Capita Income & $\begin{array}{c}-0.093 \\
(0.121)\end{array}$ & $\begin{array}{c}0.004 \\
(0.096)\end{array}$ & $\begin{array}{c}0.089 \\
(0.060)\end{array}$ & $\begin{array}{l}-0.057 \\
(0.087)\end{array}$ & $\begin{array}{l}-0.089 \\
(0.095)\end{array}$ & $\begin{array}{c}0.111 \\
(0.114)\end{array}$ \\
\hline Domestic Credit & $\begin{array}{l}-0.068 \\
(0.050)\end{array}$ & $\begin{array}{l}0.064 * \\
(0.033)\end{array}$ & $\begin{array}{c}0.004 \\
(0.031)\end{array}$ & $\begin{array}{l}0.071 * \\
(0.038)\end{array}$ & $\begin{array}{c}0.013 \\
(0.032)\end{array}$ & $\begin{array}{l}-0.052 \\
(0.053)\end{array}$ \\
\hline Market Capitalization & $\begin{array}{c}0.038 \\
(0.045)\end{array}$ & $\begin{array}{l}-0.021 \\
(0.030)\end{array}$ & $\begin{array}{l}-0.017 \\
(0.026)\end{array}$ & $\begin{array}{c}-0.060 * * \\
(0.024)\end{array}$ & $\begin{array}{c}0.061 * * \\
(0.024)\end{array}$ & $\begin{array}{l}-0.011 \\
(0.035)\end{array}$ \\
\hline Trade Openness & $\begin{array}{c}-0.032 \\
(0.042)\end{array}$ & $\begin{array}{c}0.025 \\
(0.035)\end{array}$ & $\begin{array}{c}0.007 \\
(0.040)\end{array}$ & $\begin{array}{c}0.017 \\
(0.037)\end{array}$ & $\begin{array}{c}0.055 \\
(0.042)\end{array}$ & $\begin{array}{c}-0.103^{*} \\
(0.059)\end{array}$ \\
\hline Financial Openness & $\begin{array}{l}0.012^{*} \\
(0.006)\end{array}$ & $\begin{array}{c}-0.009 \\
(0.006)\end{array}$ & $\begin{array}{c}-0.003 \\
(0.004)\end{array}$ & $\begin{array}{c}0.007 \\
(0.005)\end{array}$ & $\begin{array}{l}-0.010^{*} \\
(0.006)\end{array}$ & $\begin{array}{c}0.011^{*} \\
(0.006)\end{array}$ \\
\hline Capital Openness & $\begin{array}{c}0.039 \\
(0.044)\end{array}$ & $\begin{array}{c}-0.028 \\
(0.034)\end{array}$ & $\begin{array}{l}-0.010 \\
(0.028)\end{array}$ & $\begin{array}{c}-0.019 \\
(0.031)\end{array}$ & $\begin{array}{c}0.024 \\
(0.023)\end{array}$ & $\begin{array}{c}0.011 \\
(0.034)\end{array}$ \\
\hline Net Foreign Assets & $\begin{array}{c}-0.001 \\
(0.024)\end{array}$ & $\begin{array}{l}-0.005 \\
(0.019)\end{array}$ & $\begin{array}{c}0.006 \\
(0.014)\end{array}$ & $\begin{array}{l}-0.009 \\
(0.018)\end{array}$ & $\begin{array}{c}0.024 \\
(0.020)\end{array}$ & $\begin{array}{c}-0.012 \\
(0.027)\end{array}$ \\
\hline Foreign Reserves & $\begin{array}{c}0.171 \\
(0.126)\end{array}$ & $\begin{array}{l}-0.138 \\
(0.090)\end{array}$ & $\begin{array}{l}-0.032 \\
(0.089)\end{array}$ & $\begin{array}{l}-0.116 \\
(0.094)\end{array}$ & $\begin{array}{c}-0.278^{* * *} \\
(0.085)\end{array}$ & $\begin{array}{c}0.349 * * * \\
(0.114)\end{array}$ \\
\hline Constant & $\begin{array}{c}80.001 * * * \\
(9.414)\end{array}$ & $\begin{array}{l}11.779 \\
(7.723)\end{array}$ & $\begin{array}{l}8.220 * \\
(4.285)\end{array}$ & $\begin{array}{c}50.129 * * * \\
(6.347)\end{array}$ & $\begin{array}{c}28.898 * * * \\
(8.247)\end{array}$ & $\begin{array}{c}19.113^{* *} \\
(8.268)\end{array}$ \\
\hline Observations & 53 & 53 & 53 & 53 & 53 & 53 \\
\hline R-squared & 0.132 & 0.117 & 0.085 & 0.207 & 0.174 & 0.125 \\
\hline
\end{tabular}

Notes: Dependent variables are the "duration" and "occurrence" of "normal", "surge", and "stop" episodes as shown in Table A11 in Appendix 4. Output volatility refers to the standard deviation of annual output growth. Per capital income is in log multiplied by 10. Capital openness refers to the Chinn-Ito normalized index (2006) multiplied by 100 . Domestic credit, market capitalization, trade openness, financial openness, net foreign assets, and foreign reserves are in percent of nominal GDP. Robust standard errors are in parenthesis. ${ }^{* * *} p<0.01,{ }^{* *} p<0.05, * p<0.1$. 
Table 10: State-Dependence Variables on Domestic Factors, Equity Inflows (Excluding Ireland and Singapore)

\begin{tabular}{|c|c|c|c|c|c|c|}
\hline VARIABLES & $\begin{array}{c}\text { (1) } \\
\text { Duration } \\
\text { Normal } \\
\end{array}$ & $\begin{array}{c}\text { (2) } \\
\text { Duration } \\
\text { Surge } \\
\end{array}$ & $\begin{array}{c}\text { (3) } \\
\text { Duration } \\
\text { Stop } \\
\end{array}$ & $\begin{array}{c}\text { (4) } \\
\text { Occurrence } \\
\text { Nornal } \\
\end{array}$ & $\begin{array}{c}\text { (5) } \\
\text { Occurrence } \\
\text { Surge } \\
\end{array}$ & $\begin{array}{c}(6) \\
\text { Occurrence } \\
\text { Stop } \\
\end{array}$ \\
\hline Output Volatility & $\begin{array}{c}0.283 \\
(0.841)\end{array}$ & $\begin{array}{l}-0.752 \\
(0.533)\end{array}$ & $\begin{array}{c}0.303 \\
(0.390)\end{array}$ & $\begin{array}{l}-0.005 \\
(0.397)\end{array}$ & $\begin{array}{l}-0.653 \\
(0.482)\end{array}$ & $\begin{array}{l}-0.149 \\
(0.516)\end{array}$ \\
\hline Per Capita Income & $\begin{array}{l}-0.031 \\
(0.128)\end{array}$ & $\begin{array}{l}-0.047 \\
(0.089)\end{array}$ & $\begin{array}{c}0.088 \\
(0.079)\end{array}$ & $\begin{array}{c}0.011 \\
(0.075)\end{array}$ & $\begin{array}{l}-0.128 \\
(0.076)\end{array}$ & $\begin{array}{c}0.126 \\
(0.109)\end{array}$ \\
\hline Domestic Credit & $\begin{array}{l}-0.009 \\
(0.048)\end{array}$ & $\begin{array}{c}0.013 \\
(0.033)\end{array}$ & $\begin{array}{l}-0.012 \\
(0.023)\end{array}$ & $\begin{array}{c}0.037 \\
(0.022)\end{array}$ & $\begin{array}{l}-0.019 \\
(0.027)\end{array}$ & $\begin{array}{l}-0.021 \\
(0.032)\end{array}$ \\
\hline Market Capitalization & $\begin{array}{c}0.011 \\
(0.029)\end{array}$ & $\begin{array}{l}-0.005 \\
(0.023)\end{array}$ & $\begin{array}{l}-0.007 \\
(0.018)\end{array}$ & $\begin{array}{l}-0.034 \\
(0.026)\end{array}$ & $\begin{array}{l}0.047^{*} \\
(0.027)\end{array}$ & $\begin{array}{c}0.002 \\
(0.029)\end{array}$ \\
\hline Trade Openness & $\begin{array}{c}0.019 \\
(0.053)\end{array}$ & $\begin{array}{c}0.041 \\
(0.037)\end{array}$ & $\begin{array}{l}-0.041 \\
(0.030)\end{array}$ & $\begin{array}{c}0.014 \\
(0.026)\end{array}$ & $\begin{array}{c}0.065 \\
(0.054)\end{array}$ & $\begin{array}{c}-0.093^{* *} \\
(0.043)\end{array}$ \\
\hline Financial Openness & $\begin{array}{c}0.001 \\
(0.008)\end{array}$ & $\begin{array}{c}0.004 \\
(0.005)\end{array}$ & $\begin{array}{l}-0.008^{*} \\
(0.004)\end{array}$ & $\begin{array}{c}0.003 \\
(0.006)\end{array}$ & $\begin{array}{c}0.003 \\
(0.010)\end{array}$ & $\begin{array}{l}-0.002 \\
(0.006)\end{array}$ \\
\hline Capital Openness & $\begin{array}{l}0.088^{*} \\
(0.048)\end{array}$ & $\begin{array}{c}-0.106^{* * *} \\
(0.037)\end{array}$ & $\begin{array}{c}0.033 \\
(0.030)\end{array}$ & $\begin{array}{l}-0.024 \\
(0.030)\end{array}$ & $\begin{array}{c}0.001 \\
(0.030)\end{array}$ & $\begin{array}{c}0.060 \\
(0.047)\end{array}$ \\
\hline Net Foreign Assets & $\begin{array}{l}-0.010 \\
(0.031)\end{array}$ & $\begin{array}{c}0.007 \\
(0.023)\end{array}$ & $\begin{array}{c}0.006 \\
(0.014)\end{array}$ & $\begin{array}{l}-0.011 \\
(0.017)\end{array}$ & $\begin{array}{c}0.021 \\
(0.022)\end{array}$ & $\begin{array}{l}-0.001 \\
(0.024)\end{array}$ \\
\hline Foreign Reserves & $\begin{array}{l}-0.100 \\
(0.208)\end{array}$ & $\begin{array}{c}0.045 \\
(0.124)\end{array}$ & $\begin{array}{c}0.090 \\
(0.100)\end{array}$ & $\begin{array}{l}-0.147 \\
(0.106)\end{array}$ & $\begin{array}{c}0.057 \\
(0.105)\end{array}$ & $\begin{array}{c}0.107 \\
(0.115)\end{array}$ \\
\hline Constant & $\begin{array}{c}66.090^{* * *} \\
(9.791)\end{array}$ & $\begin{array}{c}27.524^{* * *} \\
(5.528)\end{array}$ & $\begin{array}{c}5.189 \\
(6.366)\end{array}$ & $\begin{array}{c}44.553^{* * *} \\
(5.833)\end{array}$ & $\begin{array}{c}36.060^{* * *} \\
(5.263)\end{array}$ & $\begin{array}{l}12.851 \\
(7.972)\end{array}$ \\
\hline Observations & 53 & 52 & 53 & 53 & 52 & 53 \\
\hline R-squared & 0.133 & 0.305 & 0.153 & 0.124 & 0.214 & 0.261 \\
\hline
\end{tabular}


Table 11: State-Dependence Variables on Domestic Factors, Total Gross Inflows (Replacing NFA with Foreign Debt Liabilities)

\begin{tabular}{|c|c|c|c|c|c|c|}
\hline VARIABLES & $\begin{array}{c}(1) \\
\text { Duration } \\
\text { Normal } \\
\end{array}$ & $\begin{array}{c}\text { (2) } \\
\text { Duration } \\
\text { Surge } \\
\end{array}$ & $\begin{array}{c}\text { (3) } \\
\text { Duration } \\
\text { Stop } \\
\end{array}$ & $\begin{array}{c}(4) \\
\text { Occurrence } \\
\text { Nornal }\end{array}$ & $\begin{array}{c}\text { (5) } \\
\text { Occurrence } \\
\text { Surge }\end{array}$ & $\begin{array}{c}\text { (6) } \\
\text { Occurrence } \\
\text { Stop } \\
\end{array}$ \\
\hline Output Volatility & $\begin{array}{c}-0.453 \\
(0.728)\end{array}$ & $\begin{array}{c}0.624 \\
(0.647)\end{array}$ & $\begin{array}{l}-0.171 \\
(0.280)\end{array}$ & $\begin{array}{c}-0.803^{* *} \\
(0.308)\end{array}$ & $\begin{array}{c}-0.798 \\
(0.531)\end{array}$ & $\begin{array}{c}0.115 \\
(0.574)\end{array}$ \\
\hline Per Capita Income & $\begin{array}{c}0.057 \\
(0.122)\end{array}$ & $\begin{array}{l}-0.131 \\
(0.096)\end{array}$ & $\begin{array}{c}0.074 \\
(0.062)\end{array}$ & $\begin{array}{c}0.039 \\
(0.076)\end{array}$ & $\begin{array}{l}-0.134 \\
(0.096)\end{array}$ & $\begin{array}{c}0.093 \\
(0.105)\end{array}$ \\
\hline Domestic Credit & $\begin{array}{l}-0.046 \\
(0.041)\end{array}$ & $\begin{array}{c}0.050 \\
(0.033)\end{array}$ & $\begin{array}{l}-0.004 \\
(0.022)\end{array}$ & $\begin{array}{c}0.016 \\
(0.020)\end{array}$ & $\begin{array}{c}0.008 \\
(0.035)\end{array}$ & $\begin{array}{l}-0.028 \\
(0.030)\end{array}$ \\
\hline Market Capitalization & $\begin{array}{c}0.018 \\
(0.037)\end{array}$ & $\begin{array}{l}-0.015 \\
(0.030)\end{array}$ & $\begin{array}{l}-0.003 \\
(0.023)\end{array}$ & $\begin{array}{l}-0.021 \\
(0.021)\end{array}$ & $\begin{array}{c}0.020 \\
(0.031)\end{array}$ & $\begin{array}{c}0.012 \\
(0.029)\end{array}$ \\
\hline Trade Openness & $\begin{array}{c}-0.051 \\
(0.045)\end{array}$ & $\begin{array}{c}0.036 \\
(0.039)\end{array}$ & $\begin{array}{c}0.016 \\
(0.025)\end{array}$ & $\begin{array}{c}0.004 \\
(0.030)\end{array}$ & $\begin{array}{c}-0.008 \\
(0.047)\end{array}$ & $\begin{array}{l}-0.036 \\
(0.036)\end{array}$ \\
\hline Financial Openness & $\begin{array}{c}0.006 \\
(0.013)\end{array}$ & $\begin{array}{c}0.004 \\
(0.015)\end{array}$ & $\begin{array}{l}-0.010^{*} \\
(0.006)\end{array}$ & $\begin{array}{c}0.004 \\
(0.012)\end{array}$ & $\begin{array}{c}0.010 \\
(0.018)\end{array}$ & $\begin{array}{c}-0.012 \\
(0.015)\end{array}$ \\
\hline Capital Openness & $\begin{array}{c}0.019 \\
(0.044)\end{array}$ & $\begin{array}{l}-0.047 \\
(0.032)\end{array}$ & $\begin{array}{c}0.029 \\
(0.025)\end{array}$ & $\begin{array}{l}-0.005 \\
(0.030)\end{array}$ & $\begin{array}{c}-0.004 \\
(0.031)\end{array}$ & $\begin{array}{l}0.051 * \\
(0.027)\end{array}$ \\
\hline Foreign Debt Liabilities & $\begin{array}{l}-0.035 \\
(0.038)\end{array}$ & $\begin{array}{c}0.020 \\
(0.038)\end{array}$ & $\begin{array}{c}0.015 \\
(0.020)\end{array}$ & $\begin{array}{l}-0.018 \\
(0.041)\end{array}$ & $\begin{array}{c}0.006 \\
(0.049)\end{array}$ & $\begin{array}{c}0.022 \\
(0.042)\end{array}$ \\
\hline Foreign Reserves & $\begin{array}{c}0.279 * * \\
(0.133)\end{array}$ & $\begin{array}{c}-0.231^{*} \\
(0.127)\end{array}$ & $\begin{array}{c}-0.048 \\
(0.064)\end{array}$ & $\begin{array}{l}-0.019 \\
(0.086)\end{array}$ & $\begin{array}{c}-0.082 \\
(0.143)\end{array}$ & $\begin{array}{c}0.122 \\
(0.102)\end{array}$ \\
\hline Constant & $\begin{array}{c}69.583^{* * *} \\
(9.994)\end{array}$ & $\begin{array}{c}23.613^{* * *} \\
(8.095)\end{array}$ & $\begin{array}{c}6.804 \\
(4.587)\end{array}$ & $\begin{array}{c}44.834^{* * *} \\
(6.369)\end{array}$ & $\begin{array}{c}37.537^{* * *} \\
(7.561)\end{array}$ & $\begin{array}{l}14.427 \\
(9.166)\end{array}$ \\
\hline Observations & 55 & 55 & 55 & 55 & 55 & 55 \\
\hline R-squared & 0.120 & 0.201 & 0.195 & 0.189 & 0.179 & 0.109 \\
\hline
\end{tabular}

Notes: Dependent variables are the "duration" and "occurrence" of "normal", "surge", and "stop" episodes as shown in Table A10 in Appendix 4. Output volatility refers to the standard deviation of annual output growth. Per capital income is in log multiplied by 10. Capital openness refers to the Chinn-Ito normalized index (2006) multiplied by 100 . Domestic credit, market capitalization, trade openness, financial openness, foreign debt liabilities, and foreign reserves are in percent of nominal GDP. Robust standard errors are in parenthesis. ${ }^{* * *} p<0.01,{ }^{* *} p<0.05,{ }^{*} p<0.1$. 
Table 12: State-Dependence Variables on Domestic Factors,

Debt Inflows (Replacing NFA with Foreign Debt Liabilities)

\begin{tabular}{|c|c|c|c|c|c|c|}
\hline VARIABLES & $\begin{array}{c}(1) \\
\text { Duration } \\
\text { Normal } \\
\end{array}$ & $\begin{array}{c}(2) \\
\text { Duration } \\
\text { Surge } \\
\end{array}$ & $\begin{array}{c}\text { (3) } \\
\text { Duration } \\
\text { Stop } \\
\end{array}$ & \begin{tabular}{|c|}
$(4)$ \\
Occurrence \\
Nornal
\end{tabular} & $\begin{array}{c}\text { (5) } \\
\text { Occurrence } \\
\text { Surge }\end{array}$ & $\begin{array}{c}\text { (6) } \\
\text { Occurrence } \\
\text { Stop } \\
\end{array}$ \\
\hline Output Volatility & $\begin{array}{l}-0.036 \\
(0.644)\end{array}$ & $\begin{array}{c}0.371 \\
(0.555)\end{array}$ & $\begin{array}{l}-0.335 \\
(0.409)\end{array}$ & $\begin{array}{l}-0.756 \\
(0.623)\end{array}$ & $\begin{array}{c}0.280 \\
(0.586)\end{array}$ & $\begin{array}{l}-0.551 \\
(0.726)\end{array}$ \\
\hline Per Capita Income & $\begin{array}{c}-0.071 \\
(0.122)\end{array}$ & $\begin{array}{l}-0.025 \\
(0.098)\end{array}$ & $\begin{array}{c}0.095 \\
(0.060)\end{array}$ & $\begin{array}{l}-0.050 \\
(0.088)\end{array}$ & $\begin{array}{l}-0.109 \\
(0.101)\end{array}$ & $\begin{array}{c}0.131 \\
(0.119)\end{array}$ \\
\hline Domestic Credit & $\begin{array}{l}-0.059 \\
(0.049)\end{array}$ & $\begin{array}{l}0.059 * \\
(0.032)\end{array}$ & $\begin{array}{l}-0.000 \\
(0.031)\end{array}$ & $\begin{array}{c}0.058 \\
(0.036)\end{array}$ & $\begin{array}{c}0.022 \\
(0.034)\end{array}$ & $\begin{array}{l}-0.054 \\
(0.052)\end{array}$ \\
\hline Market Capitalization & $\begin{array}{c}0.036 \\
(0.043)\end{array}$ & $\begin{array}{l}-0.024 \\
(0.030)\end{array}$ & $\begin{array}{l}-0.011 \\
(0.024)\end{array}$ & $\begin{array}{c}-0.041^{*} \\
(0.021)\end{array}$ & $\begin{array}{c}0.041 \\
(0.025)\end{array}$ & $\begin{array}{c}0.001 \\
(0.033)\end{array}$ \\
\hline Trade Openness & $\begin{array}{c}-0.032 \\
(0.043)\end{array}$ & $\begin{array}{c}0.020 \\
(0.036)\end{array}$ & $\begin{array}{c}0.011 \\
(0.038)\end{array}$ & $\begin{array}{c}0.035 \\
(0.037)\end{array}$ & $\begin{array}{c}0.033 \\
(0.044)\end{array}$ & $\begin{array}{l}-0.089 \\
(0.060)\end{array}$ \\
\hline Financial Openness & $\begin{array}{c}0.004 \\
(0.009)\end{array}$ & $\begin{array}{l}-0.001 \\
(0.010)\end{array}$ & $\begin{array}{l}-0.003 \\
(0.006)\end{array}$ & $\begin{array}{l}-0.005 \\
(0.008)\end{array}$ & $\begin{array}{c}0.009 \\
(0.012)\end{array}$ & $\begin{array}{l}-0.004 \\
(0.012)\end{array}$ \\
\hline Capital Openness & $\begin{array}{c}0.048 \\
(0.044)\end{array}$ & $\begin{array}{l}-0.040 \\
(0.034)\end{array}$ & $\begin{array}{l}-0.008 \\
(0.027)\end{array}$ & $\begin{array}{l}-0.010 \\
(0.030)\end{array}$ & $\begin{array}{c}0.008 \\
(0.025)\end{array}$ & $\begin{array}{c}0.025 \\
(0.033)\end{array}$ \\
\hline Foreign Debt Liabilities & $\begin{array}{l}-0.015 \\
(0.025)\end{array}$ & $\begin{array}{c}0.020 \\
(0.026)\end{array}$ & $\begin{array}{l}-0.005 \\
(0.017)\end{array}$ & $\begin{array}{c}0.024 \\
(0.025)\end{array}$ & $\begin{array}{l}-0.018 \\
(0.031)\end{array}$ & $\begin{array}{c}0.009 \\
(0.034)\end{array}$ \\
\hline Foreign Reserves & $\begin{array}{c}0.104 \\
(0.129)\end{array}$ & $\begin{array}{l}-0.107 \\
(0.095)\end{array}$ & $\begin{array}{c}0.003 \\
(0.091)\end{array}$ & $\begin{array}{c}-0.077 \\
(0.093)\end{array}$ & $\begin{array}{c}-0.253^{* *} \\
(0.100)\end{array}$ & $\begin{array}{c}0.316^{* *} \\
(0.125)\end{array}$ \\
\hline Constant & $\begin{array}{c}79.665^{* * *} \\
(9.146)\end{array}$ & $\begin{array}{l}\text { 13.038* } \\
(7.606)\end{array}$ & $\begin{array}{l}7.297^{*} \\
(4.153)\end{array}$ & $\begin{array}{c}48.702^{* * *} \\
(6.591)\end{array}$ & $\begin{array}{c}29.833^{* * *} \\
(8.511)\end{array}$ & $\begin{array}{c}18.136^{* *} \\
(8.648)\end{array}$ \\
\hline Observations & 55 & 55 & 55 & 55 & 55 & 55 \\
\hline R-squared & 0.100 & 0.113 & 0.089 & 0.179 & 0.162 & 0.123 \\
\hline
\end{tabular}

Notes: Dependent variables are the "duration" and "occurrence" of "normal", "surge", and "stop" episodes as shown in Table A11 in Appendix 4. Output volatility refers to the standard deviation of annual output growth. Per capital income is in log multiplied by 10. Capital openness refers to the Chinn-Ito normalized index (2006) multiplied by 100. Domestic credit, market capitalization, trade openness, financial openness, foreign debt liabilities, and foreign reserves are in percent of nominal GDP. Robust standard errors are in parenthesis. ${ }^{* * *} p<0.01,{ }^{* *} p<0.05,{ }^{*} p<0.1$. 
Table 13: State-Dependence Variables on Domestic Factors, Equity Inflows (Replacing NFA with Foreign Debt Liabilities)

\begin{tabular}{|c|c|c|c|c|c|c|}
\hline VARIABLES & $\begin{array}{c}(1) \\
\text { Duration } \\
\text { Normal } \\
\end{array}$ & $\begin{array}{c}(2) \\
\text { Duration } \\
\text { Surge } \\
\end{array}$ & $\begin{array}{c}\text { (3) } \\
\text { Duration } \\
\text { Stop } \\
\end{array}$ & \begin{tabular}{|c|} 
(4) \\
Occurrence \\
Nornal \\
\end{tabular} & $\begin{array}{c}\text { (5) } \\
\text { Occurrence } \\
\text { Surge }\end{array}$ & $\begin{array}{c}(6) \\
\text { Occurrence } \\
\text { Stop } \\
\end{array}$ \\
\hline Output Volatility & $\begin{array}{c}0.089 \\
(0.796)\end{array}$ & $\begin{array}{c}-0.463 \\
(0.512)\end{array}$ & $\begin{array}{c}0.311 \\
(0.387)\end{array}$ & $\begin{array}{l}-0.089 \\
(0.387)\end{array}$ & $\begin{array}{c}-0.245 \\
(0.455)\end{array}$ & $\begin{array}{l}-0.384 \\
(0.509)\end{array}$ \\
\hline Per Capita Income & $\begin{array}{l}-0.016 \\
(0.130)\end{array}$ & $\begin{array}{l}-0.052 \\
(0.089)\end{array}$ & $\begin{array}{c}0.077 \\
(0.079)\end{array}$ & $\begin{array}{c}0.013 \\
(0.074)\end{array}$ & $\begin{array}{c}-0.114 \\
(0.075)\end{array}$ & $\begin{array}{c}0.116 \\
(0.112)\end{array}$ \\
\hline Domestic Credit & $\begin{array}{l}-0.022 \\
(0.044)\end{array}$ & $\begin{array}{c}0.033 \\
(0.033)\end{array}$ & $\begin{array}{l}-0.013 \\
(0.022)\end{array}$ & $\begin{array}{c}0.029 \\
(0.021)\end{array}$ & $\begin{array}{c}0.016 \\
(0.035)\end{array}$ & $\begin{array}{l}-0.039 \\
(0.028)\end{array}$ \\
\hline Market Capitalization & $\begin{array}{c}0.035 \\
(0.029)\end{array}$ & $\begin{array}{l}-0.030 \\
(0.021)\end{array}$ & $\begin{array}{l}-0.014 \\
(0.017)\end{array}$ & $\begin{array}{l}-0.023 \\
(0.024)\end{array}$ & $\begin{array}{c}0.014 \\
(0.028)\end{array}$ & $\begin{array}{c}0.017 \\
(0.025)\end{array}$ \\
\hline Trade Openness & $\begin{array}{c}0.042 \\
(0.054)\end{array}$ & $\begin{array}{c}0.017 \\
(0.038)\end{array}$ & $\begin{array}{c}-0.050 * \\
(0.029)\end{array}$ & $\begin{array}{c}0.025 \\
(0.026)\end{array}$ & $\begin{array}{c}0.035 \\
(0.051)\end{array}$ & $\begin{array}{c}-0.084^{*} \\
(0.043)\end{array}$ \\
\hline Financial Openness & $\begin{array}{c}-0.017 \\
(0.011)\end{array}$ & $\begin{array}{c}0.013 \\
(0.009)\end{array}$ & $\begin{array}{c}0.006 \\
(0.006)\end{array}$ & $\begin{array}{l}-0.004 \\
(0.007)\end{array}$ & $\begin{array}{c}0.006 \\
(0.014)\end{array}$ & $\begin{array}{c}0.004 \\
(0.011)\end{array}$ \\
\hline Capital Openness & $\begin{array}{c}0.103 * * \\
(0.046)\end{array}$ & $\begin{array}{c}-0.116^{* * *} \\
(0.037)\end{array}$ & $\begin{array}{c}0.024 \\
(0.029)\end{array}$ & $\begin{array}{l}-0.019 \\
(0.029)\end{array}$ & $\begin{array}{l}-0.003 \\
(0.032)\end{array}$ & $\begin{array}{c}0.057 \\
(0.046)\end{array}$ \\
\hline Foreign Debt Liabilities & $\begin{array}{c}0.033 \\
(0.037)\end{array}$ & $\begin{array}{l}-0.028 \\
(0.031)\end{array}$ & $\begin{array}{l}-0.019 \\
(0.018)\end{array}$ & $\begin{array}{c}0.014 \\
(0.024)\end{array}$ & $\begin{array}{l}-0.041 \\
(0.043)\end{array}$ & $\begin{array}{c}0.006 \\
(0.036)\end{array}$ \\
\hline Foreign Reserves & $\begin{array}{c}-0.072 \\
(0.181)\end{array}$ & $\begin{array}{l}-0.042 \\
(0.121)\end{array}$ & $\begin{array}{c}0.123 \\
(0.088)\end{array}$ & $\begin{array}{c}-0.133 \\
(0.089)\end{array}$ & $\begin{array}{l}-0.091 \\
(0.148)\end{array}$ & $\begin{array}{l}0.215^{*} \\
(0.110)\end{array}$ \\
\hline Constant & $\begin{array}{c}64.127^{* * *} \\
(9.480)\end{array}$ & $\begin{array}{c}29.480 * * * \\
(5.453)\end{array}$ & $\begin{array}{c}5.965 \\
(6.087)\end{array}$ & $\begin{array}{c}44.124^{* * *} \\
(5.459)\end{array}$ & $\begin{array}{c}37.366^{* * *} \\
(5.277)\end{array}$ & $\begin{array}{l}12.121 \\
(8.117)\end{array}$ \\
\hline Observations & 55 & 54 & 55 & 55 & 54 & 55 \\
\hline R-squared & 0.159 & 0.298 & 0.113 & 0.132 & 0.112 & 0.241 \\
\hline
\end{tabular}

Notes: Dependent variables are the "duration" and "occurrence" of "normal", "surge", and "stop" episodes as shown in Table A12 in Appendix 4. Output volatility refers to the standard deviation of annual output growth. Per capital income is in log multiplied by 10. Capital openness refers to the Chinn-Ito normalized index (2006) multiplied by 100. Domestic credit, market capitalization, trade openness, financial openness, foreign debt liabilities, and foreign reserves are in percent of nominal GDP. Robust standard errors are in parenthesis. ${ }^{* * *} p<0.01, * * p<0.05,{ }^{*} p<0.1$. 
Table 14: State-Dependence Variables on Domestic Factors, Total Gross Inflows (Fewer Domestic Factors)

\begin{tabular}{|c|c|c|c|c|c|c|}
\hline VARIABLES & $\begin{array}{c}\text { (1) } \\
\text { Duration } \\
\text { Normal }\end{array}$ & $\begin{array}{c}(2) \\
\text { Duration } \\
\text { Surge }\end{array}$ & $\begin{array}{c}\text { (3) } \\
\text { Duration } \\
\text { Stop }\end{array}$ & $\begin{array}{c}(4) \\
\text { Occurrence } \\
\text { Nornal }\end{array}$ & $\begin{array}{c}\text { (5) } \\
\text { Occurrence } \\
\text { Surge }\end{array}$ & $\begin{array}{c}(6) \\
\text { Occurrence } \\
\text { Stop }\end{array}$ \\
\hline Per Capita Income & $\begin{array}{c}0.022 \\
(0.086)\end{array}$ & $\begin{array}{l}-0.140 * \\
(0.075)\end{array}$ & $\begin{array}{c}0.118^{* * *} \\
(0.042)\end{array}$ & $\begin{array}{c}0.077 \\
(0.051)\end{array}$ & $\begin{array}{l}-0.108 \\
(0.070)\end{array}$ & $\begin{array}{c}0.117 \\
(0.078)\end{array}$ \\
\hline Market Capitalization & $\begin{array}{c}0.013 \\
(0.026)\end{array}$ & $\begin{array}{l}-0.005 \\
(0.026)\end{array}$ & $\begin{array}{c}-0.008 \\
(0.017)\end{array}$ & $\begin{array}{c}0.004 \\
(0.013)\end{array}$ & $\begin{array}{l}0.040 * \\
(0.023)\end{array}$ & $\begin{array}{l}-0.003 \\
(0.023)\end{array}$ \\
\hline Financial Openness & $\begin{array}{l}-0.006 \\
(0.005)\end{array}$ & $\begin{array}{c}0.010 \\
(0.007)\end{array}$ & $\begin{array}{c}-0.004^{*} \\
(0.002)\end{array}$ & $\begin{array}{c}-0.001 \\
(0.003)\end{array}$ & $\begin{array}{c}0.010 \\
(0.007)\end{array}$ & $\begin{array}{l}-0.007 \\
(0.005)\end{array}$ \\
\hline Foreign Reserves & $\begin{array}{c}0.137^{* *} \\
(0.068)\end{array}$ & $\begin{array}{l}-0.116^{*} \\
(0.069)\end{array}$ & $\begin{array}{l}-0.021 \\
(0.041)\end{array}$ & $\begin{array}{l}-0.056 \\
(0.040)\end{array}$ & $\begin{array}{c}-0.152^{* *} \\
(0.075)\end{array}$ & $\begin{array}{c}0.040 \\
(0.057)\end{array}$ \\
\hline Constant & $\begin{array}{c}67.972^{* * *} \\
(7.577)\end{array}$ & $\begin{array}{c}27.519 * * * \\
(6.662)\end{array}$ & $\begin{array}{c}4.509 \\
(3.522)\end{array}$ & $\begin{array}{c}38.541^{* * *} \\
(4.426)\end{array}$ & $\begin{array}{c}32.319 * * * \\
(6.000)\end{array}$ & $\begin{array}{c}14.076^{* *} \\
(7.001)\end{array}$ \\
\hline Observations & 55 & 55 & 55 & 55 & 55 & 55 \\
\hline R-squared & 0.071 & 0.127 & 0.150 & 0.086 & 0.144 & 0.068 \\
\hline
\end{tabular}


Table 15: State-Dependence Variables on Domestic Factors, Debt Inflows (Fewer Domestic Factors)

\begin{tabular}{|c|c|c|c|c|c|c|}
\hline VARIABLES & $\begin{array}{c}\text { (1) } \\
\text { Duration } \\
\text { Normal }\end{array}$ & $\begin{array}{c}\text { (2) } \\
\text { Duration } \\
\text { Surge }\end{array}$ & $\begin{array}{c}\text { (3) } \\
\text { Duration } \\
\text { Stop }\end{array}$ & \begin{tabular}{|c|}
$(4)$ \\
Occurrence \\
Nornal \\
\end{tabular} & $\begin{array}{c}\text { (5) } \\
\text { Occurrence } \\
\text { Surge }\end{array}$ & $\begin{array}{c}\text { (6) } \\
\text { Occurrence } \\
\text { Stop }\end{array}$ \\
\hline Per Capita Income & $\begin{array}{l}-0.090 \\
(0.078)\end{array}$ & $\begin{array}{l}-0.006 \\
(0.067)\end{array}$ & $\begin{array}{l}0.096 * * \\
(0.037)\end{array}$ & $\begin{array}{c}0.045 \\
(0.059)\end{array}$ & $\begin{array}{l}-0.070 \\
(0.068)\end{array}$ & $\begin{array}{c}0.092 \\
(0.079)\end{array}$ \\
\hline Market Capitalization & $\begin{array}{c}0.008 \\
(0.034)\end{array}$ & $\begin{array}{l}-0.002 \\
(0.025)\end{array}$ & $\begin{array}{l}-0.007 \\
(0.018)\end{array}$ & $\begin{array}{l}-0.002 \\
(0.015)\end{array}$ & $\begin{array}{l}0.045^{* *} \\
(0.019)\end{array}$ & $\begin{array}{l}-0.005 \\
(0.028)\end{array}$ \\
\hline Financial Openness & $\begin{array}{l}-0.000 \\
(0.005)\end{array}$ & $\begin{array}{c}0.003 \\
(0.005)\end{array}$ & $\begin{array}{l}-0.003^{*} \\
(0.002)\end{array}$ & $\begin{array}{c}0.002 \\
(0.003)\end{array}$ & $\begin{array}{c}0.006 \\
(0.004)\end{array}$ & $\begin{array}{l}-0.007^{*} \\
(0.004)\end{array}$ \\
\hline Foreign Reserves & $\begin{array}{c}0.035 \\
(0.059)\end{array}$ & $\begin{array}{l}-0.047 \\
(0.052)\end{array}$ & $\begin{array}{c}0.012 \\
(0.035)\end{array}$ & $\begin{array}{l}-0.049 \\
(0.041)\end{array}$ & $\begin{array}{c}-0.151^{* * *} \\
(0.052)\end{array}$ & $\begin{array}{c}0.064 \\
(0.051)\end{array}$ \\
\hline Constant & $\begin{array}{c}80.307^{* * *} \\
(6.826)\end{array}$ & $\begin{array}{c}13.956 * * \\
(5.889)\end{array}$ & $\begin{array}{l}5.737^{*} \\
(3.252)\end{array}$ & $\begin{array}{c}40.793^{* * *} \\
(5.157)\end{array}$ & $\begin{array}{c}29.061^{* * *} \\
(6.125)\end{array}$ & $\begin{array}{c}16.848^{* *} \\
(6.956)\end{array}$ \\
\hline $\begin{array}{l}\text { Observations } \\
\text { R-squared }\end{array}$ & $\begin{array}{c}55 \\
0.044\end{array}$ & $\begin{array}{c}55 \\
0.023\end{array}$ & $\begin{array}{c}55 \\
0.071\end{array}$ & $\begin{array}{c}55 \\
0.045\end{array}$ & $\begin{array}{c}55 \\
0.134\end{array}$ & $\begin{array}{c}55 \\
0.039\end{array}$ \\
\hline
\end{tabular}

Notes: Dependent variables are the "duration" and "occurrence" of "normal", "surge", and "stop" episodes as shown in Table A11 in Appendix 4. Per capital income is in log multiplied by 10. Market capitalization, financial openness, and foreign reserves are in percent of nominal GDP. Robust standard errors are in parenthesis. ${ }^{* * *} p<0.01,{ }^{* *} p<0.05,{ }^{*} p<0.1$. 
Table 16: State-Dependence Variables on Domestic Factors, Equity Inflows (Fewer Domestic Factors)

\begin{tabular}{|c|c|c|c|c|c|c|}
\hline VARIABLES & $\begin{array}{c}(1) \\
\text { Duration } \\
\text { Normal }\end{array}$ & $\begin{array}{c}\text { (2) } \\
\text { Duration } \\
\text { Surge }\end{array}$ & $\begin{array}{c}\text { (3) } \\
\text { Duration } \\
\text { Stop }\end{array}$ & $\begin{array}{c}\text { (4) } \\
\text { Occurrence } \\
\text { Nornal }\end{array}$ & $\begin{array}{c}\text { (5) } \\
\text { Occurrence } \\
\text { Surge }\end{array}$ & $\begin{array}{c}\text { (6) } \\
\text { Occurrence } \\
\text { Stop }\end{array}$ \\
\hline Per Capita Income & $\begin{array}{c}0.104 \\
(0.099)\end{array}$ & $\begin{array}{c}-0.150 * * \\
(0.062)\end{array}$ & $\begin{array}{c}0.073 \\
(0.051)\end{array}$ & $\begin{array}{c}0.034 \\
(0.048)\end{array}$ & $\begin{array}{l}-0.087 \\
(0.052)\end{array}$ & $\begin{array}{c}0.139 * * \\
(0.066)\end{array}$ \\
\hline Market Capitalization & $\begin{array}{c}0.005 \\
(0.025)\end{array}$ & $\begin{array}{l}-0.000 \\
(0.022)\end{array}$ & $\begin{array}{l}-0.016 \\
(0.017)\end{array}$ & $\begin{array}{l}-0.011 \\
(0.017)\end{array}$ & $\begin{array}{c}0.027 \\
(0.018)\end{array}$ & $\begin{array}{c}0.015 \\
(0.028)\end{array}$ \\
\hline Financial Openness & $\begin{array}{l}-0.003 \\
(0.007)\end{array}$ & $\begin{array}{c}0.004 \\
(0.004)\end{array}$ & $\begin{array}{c}-0.002 \\
(0.003)\end{array}$ & $\begin{array}{c}0.001 \\
(0.002)\end{array}$ & $\begin{array}{l}-0.002 \\
(0.005)\end{array}$ & $\begin{array}{c}0.002 \\
(0.003)\end{array}$ \\
\hline Foreign Reserves & $\begin{array}{c}0.039 \\
(0.123)\end{array}$ & $\begin{array}{c}-0.026 \\
(0.089)\end{array}$ & $\begin{array}{c}0.023 \\
(0.045)\end{array}$ & $\begin{array}{c}-0.083^{*} \\
(0.045)\end{array}$ & $\begin{array}{l}-0.016 \\
(0.086)\end{array}$ & $\begin{array}{l}-0.013 \\
(0.061)\end{array}$ \\
\hline Constant & $\begin{array}{c}60.352^{* * *} \\
(8.554)\end{array}$ & $\begin{array}{c}31.335^{* * *} \\
(5.318)\end{array}$ & $\begin{array}{c}6.523 \\
(4.491)\end{array}$ & $\begin{array}{c}43.080^{* * *} \\
(4.160)\end{array}$ & $\begin{array}{c}34.296^{* * *} \\
(4.308)\end{array}$ & $\begin{array}{c}8.359 \\
(5.771)\end{array}$ \\
\hline Observations & 55 & $\begin{array}{c}54 \\
0102\end{array}$ & 55 & 55 & 54 & 55 \\
\hline
\end{tabular}


Table 17: Bivariate Estimates of State-Dependence Variables on Domestic Factors, (Total Gross Inflows)

\begin{tabular}{|c|c|c|c|c|c|c|}
\hline VARIABLES & $\begin{array}{c}\text { (1) } \\
\text { Duration } \\
\text { Normal }\end{array}$ & $\begin{array}{c}\text { (2) } \\
\text { Duration } \\
\text { Surge } \\
\end{array}$ & $\begin{array}{c}\text { (3) } \\
\text { Duration } \\
\text { Stop } \\
\end{array}$ & \begin{tabular}{|c|} 
(4) \\
Occurrence \\
Nornal
\end{tabular} & $\begin{array}{c}\text { (5) } \\
\text { Occurrence } \\
\text { Surge }\end{array}$ & $\begin{array}{c}\text { (6) } \\
\text { Occurrence } \\
\text { Stop }\end{array}$ \\
\hline Output Volatility & $\begin{array}{l}-0.080 \\
(0.590)\end{array}$ & $\begin{array}{c}0.436 \\
(0.533)\end{array}$ & $\begin{array}{c}-0.357 \\
(0.245)\end{array}$ & $\begin{array}{c}-0.907^{* * *} \\
(0.234)\end{array}$ & $\begin{array}{c}-0.981^{* *} \\
(0.439)\end{array}$ & $\begin{array}{l}-0.048 \\
(0.408)\end{array}$ \\
\hline Per Capita Income & $\begin{array}{l}-0.021 \\
(0.071)\end{array}$ & $\begin{array}{l}-0.062 \\
(0.064)\end{array}$ & $\begin{array}{l}0.083 * * \\
(0.034)\end{array}$ & $\begin{array}{c}0.075 \\
(0.046)\end{array}$ & $\begin{array}{c}0.017 \\
(0.069)\end{array}$ & $\begin{array}{c}0.058 \\
(0.066)\end{array}$ \\
\hline Domestic Credit & $\begin{array}{l}-0.004 \\
(0.021)\end{array}$ & $\begin{array}{l}-0.008 \\
(0.017)\end{array}$ & $\begin{array}{c}0.012 \\
(0.014)\end{array}$ & $\begin{array}{l}0.025^{*} \\
(0.013)\end{array}$ & $\begin{array}{c}0.026 \\
(0.023)\end{array}$ & $\begin{array}{c}0.007 \\
(0.019)\end{array}$ \\
\hline Market Capitalization & $\begin{array}{c}0.015 \\
(0.021)\end{array}$ & $\begin{array}{l}-0.009 \\
(0.020)\end{array}$ & $\begin{array}{c}-0.006 \\
(0.014)\end{array}$ & $\begin{array}{c}0.004 \\
(0.014)\end{array}$ & $\begin{array}{c}0.037 * \\
(0.019)\end{array}$ & $\begin{array}{c}-0.002 \\
(0.019)\end{array}$ \\
\hline Trade Openness & $\begin{array}{c}0.009 \\
(0.019)\end{array}$ & $\begin{array}{l}-0.001 \\
(0.015)\end{array}$ & $\begin{array}{c}-0.008 \\
(0.010)\end{array}$ & $\begin{array}{l}-0.015 \\
(0.012)\end{array}$ & $\begin{array}{l}-0.006 \\
(0.023)\end{array}$ & $\begin{array}{l}-0.012 \\
(0.012)\end{array}$ \\
\hline Financial Openness & $\begin{array}{l}-0.002 \\
(0.005)\end{array}$ & $\begin{array}{c}0.004 \\
(0.006)\end{array}$ & $\begin{array}{c}-0.002 \\
(0.002)\end{array}$ & $\begin{array}{c}0.000 \\
(0.003)\end{array}$ & $\begin{array}{c}0.008 \\
(0.005)\end{array}$ & $\begin{array}{c}-0.004 \\
(0.005)\end{array}$ \\
\hline Capital Openness & $\begin{array}{l}-0.006 \\
(0.033)\end{array}$ & $\begin{array}{l}-0.032 \\
(0.029)\end{array}$ & $\begin{array}{c}0.038^{* *} \\
(0.016)\end{array}$ & $\begin{array}{c}0.023 \\
(0.021)\end{array}$ & $\begin{array}{c}0.012 \\
(0.030)\end{array}$ & $\begin{array}{c}0.030 \\
(0.026)\end{array}$ \\
\hline Net Foreign Assets & $\begin{array}{l}0.027^{*} \\
(0.015)\end{array}$ & $\begin{array}{l}-0.020 * \\
(0.011)\end{array}$ & $\begin{array}{c}-0.007 \\
(0.010)\end{array}$ & $\begin{array}{c}0.003 \\
(0.017)\end{array}$ & $\begin{array}{c}0.017 \\
(0.015)\end{array}$ & $\begin{array}{l}-0.006 \\
(0.012)\end{array}$ \\
\hline Foreign Reserves & $\begin{array}{c}0.115^{* *} \\
(0.051)\end{array}$ & $\begin{array}{l}-0.057 \\
(0.034)\end{array}$ & $\begin{array}{l}-0.058^{*} \\
(0.030)\end{array}$ & $\begin{array}{c}-0.065^{* *} \\
(0.025)\end{array}$ & $\begin{array}{c}-0.051 \\
(0.084)\end{array}$ & $\begin{array}{l}-0.010 \\
(0.041)\end{array}$ \\
\hline Observations & 55 & 55 & 55 & 55 & 55 & 55 \\
\hline
\end{tabular}

Notes: Dependent variables are the "duration" and "occurrence" of "normal", "surge", and "stop" episodes as shown in Table A10 in Appendix 4. Results pertain to the estimated coefficients and standard errors of bivariate regression between each state dependence variable and individual domestic factors. Robust standard errors are in parenthesis. ${ }^{* * *} p<0.01,{ }^{* *} p<0.05,{ }^{*} p<0.1$. 
Table 18: Bivariate Estimates of State-Dependence Variables on Domestic Factors, (Debt Inflows)

\begin{tabular}{|c|c|c|c|c|c|c|}
\hline VARIABLES & $\begin{array}{c}\mathbf{( 1 )} \\
\text { Duration } \\
\text { Normal } \\
\end{array}$ & $\begin{array}{c}(2) \\
\text { Duration } \\
\text { Surge } \\
\end{array}$ & $\begin{array}{c}\text { (3) } \\
\text { Duration } \\
\text { Stop } \\
\end{array}$ & $\begin{array}{c}\text { (4) } \\
\text { Occurrence } \\
\text { Nornal } \\
\end{array}$ & $\begin{array}{c}\text { (5) } \\
\text { Occurrence } \\
\text { Surge } \\
\end{array}$ & $\begin{array}{c}\text { (6) } \\
\text { Occurrence } \\
\text { Stop } \\
\end{array}$ \\
\hline Output Volatility & $\begin{array}{c}0.275 \\
(0.453)\end{array}$ & $\begin{array}{c}0.079 \\
(0.403)\end{array}$ & $\begin{array}{c}-0.354 \\
(0.316)\end{array}$ & $\begin{array}{l}-0.814 \\
(0.575)\end{array}$ & $\begin{array}{l}-0.311 \\
(0.422)\end{array}$ & $\begin{array}{c}-0.384 \\
(0.673)\end{array}$ \\
\hline Per Capita Income & $\begin{array}{c}-0.086 \\
(0.064)\end{array}$ & $\begin{array}{c}0.021 \\
(0.054)\end{array}$ & $\begin{array}{l}0.065^{*} \\
(0.033)\end{array}$ & $\begin{array}{c}0.065 \\
(0.051)\end{array}$ & $\begin{array}{c}0.028 \\
(0.061)\end{array}$ & $\begin{array}{c}0.031 \\
(0.066)\end{array}$ \\
\hline Domestic Credit & $\begin{array}{l}-0.030 \\
(0.019)\end{array}$ & $\begin{array}{c}0.019 \\
(0.015)\end{array}$ & $\begin{array}{c}0.011 \\
(0.013)\end{array}$ & $\begin{array}{l}0.033^{*} \\
(0.017)\end{array}$ & $\begin{array}{c}0.026 \\
(0.021)\end{array}$ & $\begin{array}{l}-0.001 \\
(0.023)\end{array}$ \\
\hline Market Capitalization & $\begin{array}{c}0.001 \\
(0.024)\end{array}$ & $\begin{array}{c}0.001 \\
(0.018)\end{array}$ & $\begin{array}{c}-0.002 \\
(0.014)\end{array}$ & $\begin{array}{c}0.004 \\
(0.013)\end{array}$ & $\begin{array}{l}0.036^{*} \\
(0.019)\end{array}$ & $\begin{array}{l}-0.004 \\
(0.021)\end{array}$ \\
\hline Trade Openness & $\begin{array}{c}0.006 \\
(0.011)\end{array}$ & $\begin{array}{c}-0.004 \\
(0.011)\end{array}$ & $\begin{array}{c}-0.002 \\
(0.010)\end{array}$ & $\begin{array}{c}-0.002 \\
(0.012)\end{array}$ & $\begin{array}{c}-0.002 \\
(0.014)\end{array}$ & $\begin{array}{c}-0.022 \\
(0.018)\end{array}$ \\
\hline Financial Openness & $\begin{array}{c}-0.001 \\
(0.003)\end{array}$ & $\begin{array}{c}0.002 \\
(0.004)\end{array}$ & $\begin{array}{c}-0.001 \\
(0.002)\end{array}$ & $\begin{array}{c}0.003 \\
(0.002)\end{array}$ & $\begin{array}{c}0.005 \\
(0.004)\end{array}$ & $\begin{array}{l}-0.004 \\
(0.004)\end{array}$ \\
\hline Capital Openness & $\begin{array}{c}-0.009 \\
(0.029)\end{array}$ & $\begin{array}{l}-0.007 \\
(0.024)\end{array}$ & $\begin{array}{c}0.016 \\
(0.019)\end{array}$ & $\begin{array}{c}0.025 \\
(0.022)\end{array}$ & $\begin{array}{c}0.022 \\
(0.025)\end{array}$ & $\begin{array}{c}0.003 \\
(0.029)\end{array}$ \\
\hline Net Foreign Assets & $\begin{array}{c}-0.005 \\
(0.019)\end{array}$ & $\begin{array}{c}-0.004 \\
(0.012)\end{array}$ & $\begin{array}{c}0.009 \\
(0.010)\end{array}$ & $\begin{array}{c}0.006 \\
(0.015)\end{array}$ & $\begin{array}{c}0.011 \\
(0.014)\end{array}$ & $\begin{array}{l}-0.000 \\
(0.014)\end{array}$ \\
\hline Foreign Reserves & $\begin{array}{c}0.050 \\
(0.043)\end{array}$ & $\begin{array}{l}-0.030 \\
(0.028)\end{array}$ & $\begin{array}{l}-0.020 \\
(0.027)\end{array}$ & $\begin{array}{l}-0.042 \\
(0.045)\end{array}$ & $\begin{array}{l}-0.071 \\
(0.047)\end{array}$ & $\begin{array}{c}0.016 \\
(0.040)\end{array}$ \\
\hline Observations & 55 & 55 & 55 & 55 & 55 & 55 \\
\hline
\end{tabular}


Table 19: Bivariate Estimates of State-Dependence Variables on Domestic Factors, (Equity Inflows)

\begin{tabular}{|c|c|c|c|c|c|c|}
\hline VARIABLES & $\begin{array}{c}\text { (1) } \\
\text { Duration } \\
\text { Normal }\end{array}$ & $\begin{array}{c}\text { (2) } \\
\text { Duration } \\
\text { Surge }\end{array}$ & $\begin{array}{c}\text { (3) } \\
\text { Duration } \\
\text { Stop }\end{array}$ & \begin{tabular}{|c|} 
(4) \\
$\begin{array}{c}\text { Occurrence } \\
\text { Nornal }\end{array}$ \\
\end{tabular} & $\begin{array}{c}\text { (5) } \\
\text { Occurrence } \\
\text { Surge }\end{array}$ & $\begin{array}{c}(6) \\
\text { Occurrence } \\
\text { Stop }\end{array}$ \\
\hline Output Volatility & $\begin{array}{l}-0.082 \\
(0.522)\end{array}$ & $\begin{array}{l}-0.005 \\
(0.349)\end{array}$ & $\begin{array}{c}0.131 \\
(0.330)\end{array}$ & $\begin{array}{l}-0.278 \\
(0.324)\end{array}$ & $\begin{array}{l}-0.102 \\
(0.372)\end{array}$ & $\begin{array}{c}-0.827^{* *} \\
(0.387)\end{array}$ \\
\hline Per Capita Income & $\begin{array}{c}0.084 \\
(0.069)\end{array}$ & $\begin{array}{c}-0.119^{* *} \\
(0.046)\end{array}$ & $\begin{array}{c}0.042 \\
(0.039)\end{array}$ & $\begin{array}{c}0.035 \\
(0.039)\end{array}$ & $\begin{array}{l}-0.079 * \\
(0.043)\end{array}$ & $\begin{array}{c}0.167^{* * *} \\
(0.054)\end{array}$ \\
\hline Domestic Credit & $\begin{array}{c}0.013 \\
(0.023)\end{array}$ & $\begin{array}{l}-0.020 \\
(0.020)\end{array}$ & $\begin{array}{c}0.002 \\
(0.014)\end{array}$ & $\begin{array}{c}0.008 \\
(0.014)\end{array}$ & $\begin{array}{l}-0.004 \\
(0.020)\end{array}$ & $\begin{array}{l}0.043^{* *} \\
(0.019)\end{array}$ \\
\hline Market Capitalization & $\begin{array}{c}0.015 \\
(0.021)\end{array}$ & $\begin{array}{l}-0.012 \\
(0.021)\end{array}$ & $\begin{array}{l}-0.009 \\
(0.014)\end{array}$ & $\begin{array}{l}-0.013 \\
(0.016)\end{array}$ & $\begin{array}{c}0.008 \\
(0.021)\end{array}$ & $\begin{array}{c}0.035 \\
(0.025)\end{array}$ \\
\hline Trade Openness & $\begin{array}{c}0.023 \\
(0.017)\end{array}$ & $\begin{array}{l}-0.005 \\
(0.015)\end{array}$ & $\begin{array}{l}-0.010 \\
(0.011)\end{array}$ & $\begin{array}{l}-0.015^{*} \\
(0.009)\end{array}$ & $\begin{array}{c}0.001 \\
(0.022)\end{array}$ & $\begin{array}{l}-0.006 \\
(0.028)\end{array}$ \\
\hline Financial Openness & $\begin{array}{c}0.001 \\
(0.006)\end{array}$ & $\begin{array}{l}-0.001 \\
(0.004)\end{array}$ & $\begin{array}{l}-0.001 \\
(0.002)\end{array}$ & $\begin{array}{l}-0.000 \\
(0.002)\end{array}$ & $\begin{array}{l}-0.003 \\
(0.004)\end{array}$ & $\begin{array}{l}0.006^{* *} \\
(0.003)\end{array}$ \\
\hline Capital Openness & $\begin{array}{l}0.078^{* *} \\
(0.032)\end{array}$ & $\begin{array}{c}-0.085^{* * *} \\
(0.023)\end{array}$ & $\begin{array}{c}0.016 \\
(0.021)\end{array}$ & $\begin{array}{c}0.005 \\
(0.017)\end{array}$ & $\begin{array}{l}-0.021 \\
(0.026)\end{array}$ & $\begin{array}{l}0.071^{* *} \\
(0.029)\end{array}$ \\
\hline Net Foreign Assets & $\begin{array}{c}0.008 \\
(0.029)\end{array}$ & $\begin{array}{l}-0.011 \\
(0.023)\end{array}$ & $\begin{array}{c}0.005 \\
(0.011)\end{array}$ & $\begin{array}{l}-0.016 \\
(0.016)\end{array}$ & $\begin{array}{l}-0.003 \\
(0.023)\end{array}$ & $\begin{array}{l}0.031^{*} \\
(0.017)\end{array}$ \\
\hline Foreign Reserves & $\begin{array}{c}0.019 \\
(0.094)\end{array}$ & $\begin{array}{c}0.008 \\
(0.076)\end{array}$ & $\begin{array}{l}-0.008 \\
(0.031)\end{array}$ & $\begin{array}{c}-0.092^{* *} \\
(0.036)\end{array}$ & $\begin{array}{c}0.005 \\
(0.083)\end{array}$ & $\begin{array}{l}-0.000 \\
(0.078)\end{array}$ \\
\hline Observations & 55 & 54 & 55 & 55 & 54 & 55 \\
\hline
\end{tabular}


Appendix 1: Transitional Likelihood Regressions

Table A1: Transitional Likelihood on Domestic and State Dependence Variables

(Total Gross Inflows)

\begin{tabular}{|c|c|c|c|c|c|c|c|c|c|}
\hline VARIABLES & $\begin{array}{c}\text { (1) } \\
\text { Normal to } \\
\text { Normal } \\
\end{array}$ & $\begin{array}{c}\text { (2) } \\
\text { Normal to } \\
\text { Surge } \\
\end{array}$ & $\begin{array}{c}\text { (3) } \\
\text { Normal to } \\
\text { Stop } \\
\end{array}$ & $\begin{array}{c}\text { (4) } \\
\text { Surge to } \\
\text { Normal }\end{array}$ & $\begin{array}{c}\text { (5) } \\
\text { Surge to } \\
\text { Surge } \\
\end{array}$ & $\begin{array}{c}\text { (6) } \\
\text { Surge to } \\
\text { Stop }\end{array}$ & $\begin{array}{c}(7) \\
\text { Stop to } \\
\text { Normal }\end{array}$ & $\begin{array}{c}\text { (8) } \\
\text { Stop to } \\
\text { Surge } \\
\end{array}$ & $\begin{array}{c}\text { (9) } \\
\text { Stop to } \\
\text { Stop } \\
\end{array}$ \\
\hline Duration Normal & $\begin{array}{c}0.292 * * * \\
(0.034)\end{array}$ & $\begin{array}{c}-0.202^{* * *} \\
(0.050)\end{array}$ & $\begin{array}{c}-0.131^{* * *} \\
(0.035)\end{array}$ & $\begin{array}{c}0.116 \\
(0.360)\end{array}$ & & & $\begin{array}{l}-0.187 \\
(0.152)\end{array}$ & & \\
\hline Duration Surge & & $\begin{array}{l}-0.070 \\
(0.072)\end{array}$ & & $\begin{array}{l}-0.204 \\
(0.424)\end{array}$ & $\begin{array}{c}0.737^{* * *} \\
(0.151)\end{array}$ & $\begin{array}{c}-0.504^{* *} \\
(0.150)\end{array}$ & & $\begin{array}{c}0.168 \\
(0.119)\end{array}$ & \\
\hline Duration Stop & & & $\begin{array}{l}-0.091 \\
(0.079)\end{array}$ & & & $\begin{array}{c}0.411 \\
(0.227)\end{array}$ & $\begin{array}{c}-0.846^{*} \\
(0.349)\end{array}$ & $\begin{array}{c}-0.684^{* *} \\
(0.239)\end{array}$ & $\begin{array}{c}1.035^{* * *} \\
(0.274)\end{array}$ \\
\hline Occurrence Normal & $\begin{array}{c}-0.262^{* * *} \\
(0.057)\end{array}$ & $\begin{array}{c}0.208^{* * *} \\
(0.056)\end{array}$ & $\begin{array}{c}0.217^{* * *} \\
(0.038)\end{array}$ & $\begin{array}{l}0.844^{* *} \\
(0.291)\end{array}$ & & & $\begin{array}{l}0.564^{* *} \\
(0.171)\end{array}$ & & \\
\hline Occurrence Surge & & $\begin{array}{c}0.193^{* * *} \\
(0.041)\end{array}$ & & $\begin{array}{l}0.448^{*} \\
(0.216)\end{array}$ & $\begin{array}{c}-0.615^{* * *} \\
(0.131)\end{array}$ & $\begin{array}{c}0.714^{* * *} \\
(0.167)\end{array}$ & & $\begin{array}{c}0.539 * * * \\
(0.130)\end{array}$ & \\
\hline Occurrence Stop & & & $\begin{array}{c}0.186^{* * *} \\
(0.037)\end{array}$ & & & $\begin{array}{c}0.401^{*} \\
(0.173)\end{array}$ & $\begin{array}{l}0.504^{*} \\
(0.203)\end{array}$ & $\begin{array}{c}0.826 * * * \\
(0.175)\end{array}$ & $\begin{array}{c}-0.556 * * * \\
(0.127)\end{array}$ \\
\hline Output Volatility & $\begin{array}{l}0.493^{*} \\
(0.184)\end{array}$ & $\begin{array}{c}0.032 \\
(0.132)\end{array}$ & $\begin{array}{l}-0.257^{*} \\
(0.124)\end{array}$ & $\begin{array}{l}-1.029 \\
(0.721)\end{array}$ & $\begin{array}{l}1.010^{* *} \\
(0.354)\end{array}$ & $\begin{array}{l}1.187^{* *} \\
(0.434)\end{array}$ & $\begin{array}{l}-0.562 \\
(0.499)\end{array}$ & $\begin{array}{c}0.005 \\
(0.337)\end{array}$ & $\begin{array}{l}1.071^{*} \\
(0.479)\end{array}$ \\
\hline Per Capita Income & $\begin{array}{l}-0.014 \\
(0.025)\end{array}$ & $\begin{array}{l}-0.002 \\
(0.019)\end{array}$ & $\begin{array}{c}0.018 \\
(0.019)\end{array}$ & $\begin{array}{c}0.119 \\
(0.095)\end{array}$ & $\begin{array}{l}-0.058 \\
(0.072)\end{array}$ & $\begin{array}{c}-0.091 \\
(0.069)\end{array}$ & $\begin{array}{l}-0.038 \\
(0.098)\end{array}$ & $\begin{array}{c}0.109 \\
(0.072)\end{array}$ & $\begin{array}{l}-0.026 \\
(0.099)\end{array}$ \\
\hline Domestic Credit & $\begin{array}{c}0.023 \\
(0.011)\end{array}$ & $\begin{array}{l}-0.014 \\
(0.007)\end{array}$ & $\begin{array}{l}-0.007 \\
(0.008)\end{array}$ & $\begin{array}{l}-0.029 \\
(0.042)\end{array}$ & $\begin{array}{c}0.031 \\
(0.032)\end{array}$ & $\begin{array}{c}-0.003 \\
(0.027)\end{array}$ & $\begin{array}{l}-0.024 \\
(0.035)\end{array}$ & $\begin{array}{c}0.007 \\
(0.025)\end{array}$ & $\begin{array}{c}0.007 \\
(0.034)\end{array}$ \\
\hline Market Capitalization & $\begin{array}{c}0.002 \\
(0.008)\end{array}$ & $\begin{array}{c}0.007 \\
(0.005)\end{array}$ & $\begin{array}{l}-0.013 \\
(0.006)\end{array}$ & $\begin{array}{l}-0.072 \\
(0.036)\end{array}$ & $\begin{array}{c}0.015 \\
(0.026)\end{array}$ & $\begin{array}{c}0.059 * * \\
(0.021)\end{array}$ & $\begin{array}{c}0.025 \\
(0.025)\end{array}$ & $\begin{array}{c}-0.053^{* *} \\
(0.019)\end{array}$ & $\begin{array}{c}0.025 \\
(0.027)\end{array}$ \\
\hline Trade Openness & $\begin{array}{l}0.029 * \\
(0.011)\end{array}$ & $\begin{array}{l}-0.003 \\
(0.007)\end{array}$ & $\begin{array}{l}-0.016 \\
(0.008)\end{array}$ & $\begin{array}{l}-0.039 \\
(0.043)\end{array}$ & $\begin{array}{c}0.003 \\
(0.025)\end{array}$ & $\begin{array}{c}0.050 \\
(0.029)\end{array}$ & $\begin{array}{c}0.045 \\
(0.028)\end{array}$ & $\begin{array}{l}-0.018 \\
(0.024)\end{array}$ & $\begin{array}{l}-0.004 \\
(0.037)\end{array}$ \\
\hline Financial Openness & $\begin{array}{l}-0.002 \\
(0.001)\end{array}$ & $\begin{array}{c}0.000 \\
(0.001)\end{array}$ & $\begin{array}{c}0.001 \\
(0.001)\end{array}$ & $\begin{array}{l}-0.000 \\
(0.005)\end{array}$ & $\begin{array}{c}0.002 \\
(0.003)\end{array}$ & $\begin{array}{c}-0.002 \\
(0.004)\end{array}$ & $\begin{array}{c}-0.010^{* *} \\
(0.003)\end{array}$ & $\begin{array}{l}-0.000 \\
(0.003)\end{array}$ & $\begin{array}{c}0.004 \\
(0.004)\end{array}$ \\
\hline Capit & $\begin{array}{l}-0.012 \\
(0.010)\end{array}$ & $\begin{array}{c}0.003 \\
(0.006)\end{array}$ & $\begin{array}{c}0.001 \\
(0.008)\end{array}$ & $\begin{array}{c}0.011 \\
(0.043)\end{array}$ & $\begin{array}{l}-0.016 \\
(0.021)\end{array}$ & $\begin{array}{l}-0.021 \\
(0.031)\end{array}$ & $\begin{array}{c}0.044 \\
(0.030)\end{array}$ & $\begin{array}{l}-0.030 \\
(0.031)\end{array}$ & $\begin{array}{l}-0.022 \\
(0.039)\end{array}$ \\
\hline Net Foreign Assets & $\begin{array}{c}0.004 \\
(0.006)\end{array}$ & $\begin{array}{l}-0.003 \\
(0.004)\end{array}$ & $\begin{array}{l}-0.002 \\
(0.004)\end{array}$ & $\begin{array}{c}0.016 \\
(0.016)\end{array}$ & $\begin{array}{l}-0.002 \\
(0.011)\end{array}$ & $\begin{array}{l}-0.016 \\
(0.017)\end{array}$ & $\begin{array}{l}-0.027 \\
(0.018)\end{array}$ & $\begin{array}{c}0.009 \\
(0.014)\end{array}$ & $\begin{array}{c}0.019 \\
(0.023)\end{array}$ \\
\hline Foreign Reserves & $\begin{array}{c}-0.109 * * \\
(0.036)\end{array}$ & $\begin{array}{c}0.015 \\
(0.024)\end{array}$ & $\begin{array}{l}0.082^{* *} \\
(0.024)\end{array}$ & $\begin{array}{c}0.218 \\
(0.113)\end{array}$ & $\begin{array}{l}-0.075 \\
(0.067)\end{array}$ & $\begin{array}{l}-0.134 \\
(0.092)\end{array}$ & $\begin{array}{c}0.031 \\
(0.122)\end{array}$ & $\begin{array}{c}0.112 \\
(0.057)\end{array}$ & $\begin{array}{l}-0.118 \\
(0.121)\end{array}$ \\
\hline Constant & $\begin{array}{c}82.789 * * * \\
(2.894)\end{array}$ & $\begin{array}{c}5.570 \\
(3.541)\end{array}$ & $\begin{array}{l}-0.575 \\
(2.981)\end{array}$ & $\begin{array}{l}-40.105 \\
(27.948)\end{array}$ & $\begin{array}{c}82.644^{* * *} \\
(6.334)\end{array}$ & $\begin{array}{c}-18.293^{*} \\
(7.594)\end{array}$ & $\begin{array}{c}8.089 \\
(13.588)\end{array}$ & $\begin{array}{c}-29.336^{* *} \\
(8.580)\end{array}$ & $\begin{array}{c}76.810^{* * *} \\
(7.038)\end{array}$ \\
\hline Observation & 55 & 55 & 55 & 55 & 55 & 55 & 55 & 55 & 55 \\
\hline R-squared & 0.714 & 0.778 & 0.662 & 0.547 & 0.602 & 0.503 & 0.432 & 0.536 & 0.402 \\
\hline RSS & 90.874 & 46.485 & 43.523 & 1340.972 & 737.659 & 821.768 & 924.740 & 493.297 & 1045.168 \\
\hline
\end{tabular}

Notes: Dependent variables are transitional likelihood for total gross inflows in percent as presented in Table A7 in Appendix 4. Duration and occurrence are presented in Table A10 in Appendix 4. Output volatility refers to the standard deviation of annual output growth. Per capital income is in log multiplied by 10. Capital openness refers to the Chinn-Ito normalized index (2006) multiplied by 100. Domestic credit, market capitalization, trade openness, financial openness, net foreign assets, and foreign reserves are in percent of nominal GDP. RSS pertains to the residual sum of squares. Robust standard errors are in parenthesis. ${ }^{* * *} p<0.01,{ }^{* *} p<0.05,{ }^{*} p<0.1$. 
Table A2: Transitional Likelihood on Domestic Factors

(Total Gross Inflows)

\begin{tabular}{|c|c|c|c|c|c|c|c|c|c|}
\hline VARIABLES & $\begin{array}{c}\text { (1) } \\
\text { Normal to } \\
\text { Normal }\end{array}$ & $\begin{array}{c}(2) \\
\text { Normal to } \\
\text { Surge } \\
\end{array}$ & $\begin{array}{c}(3) \\
\text { Normal to } \\
\text { Stop } \\
\end{array}$ & $\begin{array}{c}\text { (4) } \\
\text { Surge to } \\
\text { Normal }\end{array}$ & $\begin{array}{c}\text { (5) } \\
\text { Surge to } \\
\text { Surge } \\
\end{array}$ & $\begin{array}{c}\text { (6) } \\
\text { Surge to } \\
\text { Stop }\end{array}$ & $\begin{array}{c}\text { (7) } \\
\text { Stop to } \\
\text { Normal }\end{array}$ & $\begin{array}{c}\text { (8) } \\
\text { Stop to } \\
\text { Surge } \\
\end{array}$ & $\begin{array}{c}\text { (9) } \\
\text { Stop to } \\
\text { Stop }\end{array}$ \\
\hline Output Volatility & $\begin{array}{l}0.579 * * \\
(0.188)\end{array}$ & $\begin{array}{l}-0.236 \\
(0.176)\end{array}$ & $\begin{array}{l}-0.343^{*} \\
(0.137)\end{array}$ & $\begin{array}{c}-2.230 * * * \\
(0.550)\end{array}$ & $\begin{array}{c}1.927^{* * *} \\
(0.521)\end{array}$ & $\begin{array}{c}0.303 \\
(0.451)\end{array}$ & $\begin{array}{l}-0.740 \\
(0.473)\end{array}$ & $\begin{array}{l}-0.090 \\
(0.421)\end{array}$ & $\begin{array}{c}0.831 \\
(0.575)\end{array}$ \\
\hline Per Capita Income & $\begin{array}{l}-0.009 \\
(0.042)\end{array}$ & $\begin{array}{l}-0.022 \\
(0.037)\end{array}$ & $\begin{array}{c}0.031 \\
(0.025)\end{array}$ & $\begin{array}{c}0.119 \\
(0.117)\end{array}$ & $\begin{array}{l}-0.067 \\
(0.100)\end{array}$ & $\begin{array}{l}-0.052 \\
(0.094)\end{array}$ & $\begin{array}{c}-0.042 \\
(0.117)\end{array}$ & $\begin{array}{c}0.043 \\
(0.085)\end{array}$ & $\begin{array}{l}-0.000 \\
(0.124)\end{array}$ \\
\hline Domestic Credit & $\begin{array}{c}0.005 \\
(0.016)\end{array}$ & $\begin{array}{l}-0.003 \\
(0.012)\end{array}$ & $\begin{array}{l}-0.002 \\
(0.009)\end{array}$ & $\begin{array}{l}-0.029 \\
(0.040)\end{array}$ & $\begin{array}{c}0.065 \\
(0.035)\end{array}$ & $\begin{array}{l}-0.036 \\
(0.030)\end{array}$ & $\begin{array}{c}-0.017 \\
(0.039)\end{array}$ & $\begin{array}{l}-0.001 \\
(0.022)\end{array}$ & $\begin{array}{c}0.018 \\
(0.036)\end{array}$ \\
\hline Market Capitalization & $\begin{array}{c}0.014 \\
(0.012)\end{array}$ & $\begin{array}{c}0.003 \\
(0.009)\end{array}$ & $\begin{array}{c}-0.017^{*} \\
(0.008)\end{array}$ & $\begin{array}{l}-0.073^{*} \\
(0.035)\end{array}$ & $\begin{array}{l}-0.009 \\
(0.030)\end{array}$ & $\begin{array}{l}0.083^{*} \\
(0.033)\end{array}$ & $\begin{array}{c}0.020 \\
(0.031)\end{array}$ & $\begin{array}{l}-0.034^{*} \\
(0.017)\end{array}$ & $\begin{array}{c}0.015 \\
(0.032)\end{array}$ \\
\hline Trade Openness & $\begin{array}{c}0.014 \\
(0.014)\end{array}$ & $\begin{array}{c}0.004 \\
(0.011)\end{array}$ & $\begin{array}{l}-0.018 \\
(0.010)\end{array}$ & $\begin{array}{l}-0.049 \\
(0.038)\end{array}$ & $\begin{array}{c}0.031 \\
(0.029)\end{array}$ & $\begin{array}{c}0.018 \\
(0.033)\end{array}$ & $\begin{array}{c}0.027 \\
(0.036)\end{array}$ & $\begin{array}{l}-0.058 \\
(0.029)\end{array}$ & $\begin{array}{c}0.031 \\
(0.042)\end{array}$ \\
\hline Financial Openness & $\begin{array}{l}-0.003 \\
(0.003)\end{array}$ & $\begin{array}{c}0.002 \\
(0.002)\end{array}$ & $\begin{array}{c}0.000 \\
(0.001)\end{array}$ & $\begin{array}{c}0.001 \\
(0.005)\end{array}$ & $\begin{array}{c}0.002 \\
(0.003)\end{array}$ & $\begin{array}{l}-0.004 \\
(0.003)\end{array}$ & $\begin{array}{c}-0.008^{*} \\
(0.003)\end{array}$ & $\begin{array}{c}0.006 \\
(0.003)\end{array}$ & $\begin{array}{c}0.001 \\
(0.003)\end{array}$ \\
\hline Capital Openness & $\begin{array}{l}-0.005 \\
(0.013)\end{array}$ & $\begin{array}{c}0.001 \\
(0.009)\end{array}$ & $\begin{array}{c}0.004 \\
(0.010)\end{array}$ & $\begin{array}{c}0.018 \\
(0.045)\end{array}$ & $\begin{array}{l}-0.048 \\
(0.030)\end{array}$ & $\begin{array}{c}0.031 \\
(0.038)\end{array}$ & $\begin{array}{c}0.040 \\
(0.042)\end{array}$ & $\begin{array}{l}-0.019 \\
(0.032)\end{array}$ & $\begin{array}{l}-0.020 \\
(0.050)\end{array}$ \\
\hline Net Foreign Assets & $\begin{array}{c}0.008 \\
(0.008)\end{array}$ & $\begin{array}{l}-0.002 \\
(0.007)\end{array}$ & $\begin{array}{l}-0.005 \\
(0.005)\end{array}$ & $\begin{array}{c}0.025 \\
(0.020)\end{array}$ & $\begin{array}{l}-0.014 \\
(0.016)\end{array}$ & $\begin{array}{l}-0.011 \\
(0.021)\end{array}$ & $\begin{array}{r}-0.030 \\
(0.021)\end{array}$ & $\begin{array}{c}0.011 \\
(0.022)\end{array}$ & $\begin{array}{c}0.018 \\
(0.028)\end{array}$ \\
\hline Foreign Reserves & $\begin{array}{l}-0.029 \\
(0.042)\end{array}$ & $\begin{array}{l}-0.046 \\
(0.037)\end{array}$ & $\begin{array}{l}0.074^{*} \\
(0.028)\end{array}$ & $\begin{array}{l}0.228^{*} \\
(0.108)\end{array}$ & $\begin{array}{l}-0.174 * \\
(0.084)\end{array}$ & $\begin{array}{l}-0.055 \\
(0.115)\end{array}$ & $\begin{array}{c}0.075 \\
(0.146)\end{array}$ & $\begin{array}{c}0.160^{*} \\
(0.078)\end{array}$ & $\begin{array}{l}-0.235 \\
(0.142)\end{array}$ \\
\hline Constant & $\begin{array}{c}91.473 * * * \\
(3.103)\end{array}$ & $\begin{array}{l}6.561^{*} \\
(3.140)\end{array}$ & $\begin{array}{c}1.966 \\
(1.909)\end{array}$ & $\begin{array}{l}18.049 \\
(9.872)\end{array}$ & $\begin{array}{c}76.327^{* * *} \\
(9.897)\end{array}$ & $\begin{array}{c}5.625 \\
(7.143)\end{array}$ & $\begin{array}{l}21.675^{*} \\
(9.318)\end{array}$ & $\begin{array}{c}2.487 \\
(6.208)\end{array}$ & $\begin{array}{c}75.838^{* * *} \\
(9.729)\end{array}$ \\
\hline Observations & 55 & 55 & 55 & 55 & 55 & 55 & 55 & 55 & 55 \\
\hline R-squared & 0.241 & 0.152 & 0.283 & 0.341 & 0.363 & 0.159 & 0.142 & 0.134 & 0.098 \\
\hline RSS & 241.289 & 177.630 & 92.344 & 1951.451 & 1179.072 & 1388.824 & 1396.925 & 919.439 & 1578.453 \\
\hline
\end{tabular}

Notes: Dependent variables are transitional likelihood for total gross inflows in percent as presented in Table A7 in Appendix 4. Output volatility refers to the standard deviation of annual output growth. Per capital income is in log multiplied by 10 . Capital openness refers to the Chinn-Ito normalized index (2006) multiplied by 100. Domestic credit, market capitalization, trade openness, financial openness, net foreign assets, and foreign reserves are in percent of nominal GDP. RSS pertains to the residual sum of squares. Robust standard errors are in parenthesis. ${ }^{* * *} p<0.01,{ }^{* *} p<0.05,{ }^{*} p<0.1$. 
Table A3: Transitional Likelihood on Duration Dependence

(Total Gross Inflows)

\begin{tabular}{|c|c|c|c|c|c|c|c|c|c|}
\hline VARIABLES & \begin{tabular}{|c|}
$(1)$ \\
Normal to \\
Normal
\end{tabular} & $\begin{array}{c}\text { (2) } \\
\text { Normal to } \\
\text { Surge }\end{array}$ & $\begin{array}{c}\text { (3) } \\
\text { Normal to } \\
\text { Stop }\end{array}$ & $\begin{array}{c}\text { (4) } \\
\text { Surge to } \\
\text { Normal }\end{array}$ & $\begin{array}{c}\text { (5) } \\
\text { Surge to } \\
\text { Surge }\end{array}$ & $\begin{array}{c}(6) \\
\text { Surge to } \\
\text { Stop }\end{array}$ & $\begin{array}{c}\text { (7) } \\
\text { Stop to } \\
\text { Normal }\end{array}$ & $\begin{array}{c}\text { (8) } \\
\text { Stop to } \\
\text { Surge }\end{array}$ & $\begin{array}{c}\text { (9) } \\
\text { Stop to } \\
\text { Stop }\end{array}$ \\
\hline Duration Normal & $\begin{array}{c}0.207^{* * *} \\
(0.049)\end{array}$ & $\begin{array}{l}-0.085^{*} \\
(0.041)\end{array}$ & $\begin{array}{c}0.029 \\
(0.032)\end{array}$ & $\begin{array}{c}0.325 \\
(0.277)\end{array}$ & & & $\begin{array}{l}0.262^{*} \\
(0.104)\end{array}$ & & \\
\hline Duration Surge & & $\begin{array}{l}0.147^{*} \\
(0.060)\end{array}$ & & $\begin{array}{c}0.047 \\
(0.283)\end{array}$ & $\begin{array}{l}0.359^{*} \\
(0.140)\end{array}$ & $\begin{array}{l}-0.076 \\
(0.104)\end{array}$ & & $\begin{array}{c}0.145 \\
(0.093)\end{array}$ & \\
\hline Duration Stop & & & $\begin{array}{l}0.164^{* *} \\
(0.053)\end{array}$ & & & $\begin{array}{l}0.404^{*} \\
(0.180)\end{array}$ & $\begin{array}{l}-0.079 \\
(0.189)\end{array}$ & $\begin{array}{c}-0.097 \\
(0.157)\end{array}$ & $\begin{array}{l}0.421^{*} \\
(0.192)\end{array}$ \\
\hline Constant & $\begin{array}{c}78.342^{* * *} \\
(3.623)\end{array}$ & $\begin{array}{l}7.773^{*} \\
(3.631)\end{array}$ & $\begin{array}{l}-1.364 \\
(2.612)\end{array}$ & $\begin{array}{c}-7.617 \\
(23.104)\end{array}$ & $\begin{array}{c}73.006^{* * *} \\
(2.331)\end{array}$ & $\begin{array}{c}0.927 \\
(2.953)\end{array}$ & $\begin{array}{c}1.618 \\
(9.063)\end{array}$ & $\begin{array}{c}1.769 \\
(2.448)\end{array}$ & $\begin{array}{c}72.446^{* * *} \\
(3.050)\end{array}$ \\
\hline Observations & 55 & 55 & 55 & 55 & 55 & 55 & 55 & 55 & 55 \\
\hline R-squared & 0.333 & 0.492 & 0.131 & 0.071 & 0.132 & 0.089 & 0.125 & 0.047 & 0.081 \\
\hline RSS & 212.063 & 106.488 & 111.839 & 2748.632 & 1607.994 & 1504.124 & 1426.027 & 1011.704 & 1607.559 \\
\hline
\end{tabular}


Table A4: Transitional Likelihood on Occurrence Dependence

(Total Gross Inflows)

\begin{tabular}{|c|c|c|c|c|c|c|c|c|c|}
\hline VARIABLES & \begin{tabular}{|c|}
$(1)$ \\
Normal to \\
Normal
\end{tabular} & $\begin{array}{c}\text { (2) } \\
\text { Normal to } \\
\text { Surge }\end{array}$ & $\begin{array}{c}\text { (3) } \\
\text { Normal to } \\
\text { Stop } \\
\end{array}$ & $\begin{array}{c}\text { (4) } \\
\text { Surge to } \\
\text { Normal }\end{array}$ & $\begin{array}{c}\text { (5) } \\
\text { Surge to } \\
\text { Surge }\end{array}$ & $\begin{array}{c}\text { (6) } \\
\text { Surge to } \\
\text { Stop }\end{array}$ & $\begin{array}{c}\text { (7) } \\
\text { Stop to } \\
\text { Normal }\end{array}$ & $\begin{array}{c}\text { (8) } \\
\text { Stop to } \\
\text { Surge }\end{array}$ & $\begin{array}{c}\text { (9) } \\
\text { Stop to } \\
\text { Stop }\end{array}$ \\
\hline Occurrence Normal & $\begin{array}{l}-0.132 \\
(0.074)\end{array}$ & $\begin{array}{l}0.098^{*} \\
(0.043)\end{array}$ & $\begin{array}{c}0.164^{* * * *} \\
(0.042)\end{array}$ & $\begin{array}{c}1.050^{* * *} \\
(0.220)\end{array}$ & & & $\begin{array}{l}0.533^{* *} \\
(0.158)\end{array}$ & & \\
\hline Occurrence Surge & & $\begin{array}{c}0.225^{* * *} \\
(0.028)\end{array}$ & & $\begin{array}{l}0.272^{*} \\
(0.117)\end{array}$ & $\begin{array}{l}-0.200 \\
(0.116)\end{array}$ & $\begin{array}{l}0.412^{* *} \\
(0.128)\end{array}$ & & $\begin{array}{c}0.385^{* * *} \\
(0.097)\end{array}$ & \\
\hline Occurrence Stop & & & $\begin{array}{c}0.135^{* * *} \\
(0.029)\end{array}$ & & & $\begin{array}{l}0.533^{* *} \\
(0.160)\end{array}$ & $\begin{array}{c}0.190 \\
(0.126)\end{array}$ & $\begin{array}{c}0.379 * * * \\
(0.107)\end{array}$ & $\begin{array}{l}-0.208^{*} \\
(0.101)\end{array}$ \\
\hline Constant & $\begin{array}{c}98.919 * * * \\
(3.265)\end{array}$ & $\begin{array}{c}-5.941^{*} \\
(2.283)\end{array}$ & $\begin{array}{c}-7.545^{* *} \\
(2.188)\end{array}$ & $\begin{array}{c}-37.466^{* *} \\
(11.294)\end{array}$ & $\begin{array}{c}83.446^{* * *} \\
(3.129)\end{array}$ & $\begin{array}{c}-17.380^{* *} \\
(6.216)\end{array}$ & $\begin{array}{l}-9.188 \\
(8.181)\end{array}$ & $\begin{array}{c}-15.777^{* * *} \\
(4.335)\end{array}$ & $\begin{array}{c}83.119 * * * \\
(2.487)\end{array}$ \\
\hline Observations & 55 & 55 & 55 & 55 & 55 & 55 & 55 & 55 & 55 \\
\hline R-squared & 0.053 & 0.558 & 0.386 & 0.341 & 0.054 & 0.197 & 0.181 & 0.208 & 0.046 \\
\hline RSS & 301.018 & 92.607 & 79.082 & 1950.467 & 1751.891 & 1326.126 & 1333.404 & 841.225 & 1667.868 \\
\hline
\end{tabular}




\section{Appendix 2: Dataset on Capital Flows}

Our primary source for quarterly gross capital inflows data is the Balance of Payments Statistics presented in the International Monetary Fund's (IMF) International Financial Statistics (IFS). We access the data from CEIC Database. We define gross capital inflows to include foreign direct investment liabilities, portfolio investment liabilities and other investment liabilities. Our primary period coverage is from 197001 to 201404 for 55 advanced and emerging economies. Table A5 presents country list and classification along with the dates when quarterly data are available.

Table A5: Country Sample

\begin{tabular}{|c|c|c|c|}
\hline \multicolumn{2}{|c|}{ Advanced } & \multicolumn{2}{|c|}{ Emerging and Developing } \\
\hline Country & Start & Country & Start \\
\hline Australia & 1Q1970 & Argentina & 1Q1976 \\
\hline Austria & 1Q1970 & Bangladesh & 1Q1976 \\
\hline Canada & 1Q1970 & Bolivia & 1Q1988 \\
\hline Denmark & 1Q1975 & Brazil & 1Q1975 \\
\hline Finland & 1Q1975 & Chile & 1Q1987 \\
\hline France & 1Q1975 & Colombia & 1Q1992 \\
\hline Germany & 1Q1971 & Croatia & 1Q1993 \\
\hline Greece & 1Q1976 & Czech Republic & 1Q1993 \\
\hline Iceland & 1Q1976 & Estonia & 1Q1992 \\
\hline Ireland & 1Q1981 & Hungary & 4Q1989 \\
\hline Italy & 1Q1970 & India & 1Q1975 \\
\hline Japan & 1Q1977 & Indonesia & 1Q1981 \\
\hline Netherlands & 1Q1970 & Israel & 1Q1972 \\
\hline New Zealand & 1Q1980 & Jordan & 1Q1977 \\
\hline Norway & 1Q1975 & Korea & 1Q1976 \\
\hline Portugal & 1Q1975 & Latvia & 1Q1993 \\
\hline Spain & 1Q1975 & Lithuania & 1Q1993 \\
\hline Sweden & 1Q1975 & Mexico & 1Q1979 \\
\hline United Kingdom & 1Q1970 & Moldova & 1Q1994 \\
\hline United States & 1Q1973 & Pakistan & 1Q1976 \\
\hline & & Peru & 1Q1977 \\
\hline & & Philippines & 1Q1977 \\
\hline & & Poland & 1Q1985 \\
\hline & & Romania & 1Q1991 \\
\hline & & Russia & 1Q1994 \\
\hline & & Singapore & 1Q1986 \\
\hline & & Slovakia & 1Q1993 \\
\hline & & Slovenia & 1Q1992 \\
\hline & & South Africa & 1Q1985 \\
\hline & & Sri Lanka & 1Q1977 \\
\hline & & Taiwan & 1Q1981 \\
\hline & & Thailand & 1Q1976 \\
\hline & & Turkey & 1Q1984 \\
\hline & & Ukraine & 1Q1994 \\
\hline & & Venezuela & 1Q1990 \\
\hline
\end{tabular}

Several modifications are made to make the dataset usable and consistent.

- We select countries closely following the sample of Forbes and Warnock (2012a and 2012b). However, we exclude Belgium-Luxembourg, Guatemala, Hong Kong, Malaysia, Nicaragua, Panama, and Switzerland because they either have short period coverage or limited data availability for capital flows. But we add four countries to increase the sample size. These 
countries have longer quarterly gross capital inflows data available. They include Jordan, Moldova, Pakistan, and Ukraine.

- IFS reports some values in billions of U.S. dollars, while most are in millions of U.S. dollars. Although the reported unit will not affect the identification of episodes, all values are converted to millions of U.S. dollars for consistency.

- Quarterly data before 2012Q1 follows the IMF's Balance of Payments Manual 5; while data from 2012Q1 onwards follows Balance of Payment Manual 6. The signs of gross inflows categories were made consistent to that using Balance of Payments Manual 5. No attempt was made to reconcile both series as small categorical changes are made for financial account liabilities, mostly involving intra-category changes for foreign direct investment liabilities. The transition from BPM5 to BPM6 does not affect our computed aggregate gross capital inflows.

- Data for Taiwan is sourced from the Central Bank of the Republic of China (Taiwan) accessed through CEIC Database.

- For some countries, data points are extended to increase the available periods in computing for rolling mean and standard deviation. Quarterly data for Chile (1987Q1-1990Q4), Colombia (1992Q1-1995Q4), and Venezuela (1990Q1-1993Q4) are computed by dividing the annual values sourced from the IFS by four. This modification departs from Forbes and Warnock (2012a and 2012b) approach where they do not extend the series for some countries. A justification for extending the series by four years for some countries is that the actual dating of an episode will start after the fourth year or $17^{\text {th }}$ quarter from the start of available data. The extended data points will in effect be used only for computing the rolling mean and rolling standard deviation.

- Data gaps for Greece (1998Q1-1998Q4), Norway (1992Q1-1993Q4), Peru (1985Q1-1990Q4), Poland (1996Q1-1999Q4), and Slovakia (2001Q1-2001Q4) are filled in by using annual values sourced from the IFS or from national sources divided by four. Data gaps are filled in to generate continuous series needed to calculate rolling standard deviation and mean for episode identification and transitional likelihoods computation.

- Unlike Forbes and Warnock (2012a and 2012b), we do not make adjustments to fill in data gaps in the series. Forbes and Warnock (2012a and 2012b) replace interior missing data with zeros if the string of missing values is surrounded with zeros or other values; and/or used data on net error and omissions to fill in the gaps. In this paper, no adjustments are made so as to consider only those classified financial transactions from the Balance of Payments.

- Similar to Forbes and Warnock (2012a and 2012b), our computed inflows exclude financial derivative liabilities as unlike other debt instruments, no principal amount is advanced to be repaid and no investment income accrues for derivatives. 
Appendix 3: Episodes of Gross Capital Inflows

Table A6: Episodes of Capital Inflows

\begin{tabular}{|c|c|c|c|c|c|c|c|c|c|c|c|c|}
\hline \multirow{3}{*}{ Country } & \multicolumn{4}{|c|}{ Total } & \multicolumn{4}{|c|}{ Debt } & \multicolumn{4}{|c|}{ Equity } \\
\hline & \multicolumn{2}{|c|}{ SURGES } & \multicolumn{2}{|c|}{ STOPS } & \multicolumn{2}{|c|}{ SURGES } & \multicolumn{2}{|c|}{ STOPS } & \multicolumn{2}{|c|}{ SURGES } & \multicolumn{2}{|c|}{ STOPS } \\
\hline & Start & End & Start & End & Start & End & Start & End & Start & End & Start & End \\
\hline \multicolumn{13}{|c|}{ Advanced Economies } \\
\hline Australia & $1980 q 4$ & $1982 q 4$ & $1983 q 1$ & 1984q1 & $1980 q 4$ & $1983 q 1$ & 1980q1 & $1980 q 3$ & $1980 q 2$ & $1981 q 2$ & $1981 q 3$ & $1983 q 2$ \\
\hline Australia & $1988 q 4$ & 1989q1 & $1989 q 2$ & $1991 q 3$ & $1994 q 1$ & $1994 q 3$ & $1983 q 2$ & $1984 q 1$ & $1985 q 4$ & 1986q1 & $1984 q 4$ & $1985 q 1$ \\
\hline Australia & $1993 q 4$ & $1994 q 3$ & $1997 q 2$ & $1998 q 1$ & $1995 q 2$ & 1997q1 & $1990 q 4$ & $1991 q 3$ & $1986 q 4$ & $1987 q 3$ & $1996 q 3$ & $1996 q 4$ \\
\hline Australia & $1995 q 3$ & $1996 q 3$ & $2004 q 4$ & $2005 q 4$ & $2003 q 4$ & $2004 q 3$ & $1997 q 2$ & $1998 q 1$ & $1993 q 1$ & $1993 q 4$ & $2004 q 4$ & $2005 q 4$ \\
\hline Australia & $1999 q 3$ & $1999 q 4$ & & & $2009 q 3$ & $2010 q 3$ & $2007 q 3$ & $2007 q 4$ & $2006 q 1$ & $2007 q 1$ & & \\
\hline Australia & $2002 q 3$ & $2002 q 4$ & & & & & $2008 q 4$ & $2009 q 2$ & & & & \\
\hline Australia & $2003 q 4$ & $2004 q 3$ & & & & & & & & & & \\
\hline Australia & $2006 q 1$ & $2007 q 1$ & & & & & & & & & & \\
\hline Austria & $1980 q 3$ & $1980 q 4$ & $1981 q 3$ & $1982 q 3$ & $1980 q 3$ & $1980 q 4$ & 1981q3 & $1982 q 3$ & $1980 q 2$ & $1980 q 4$ & $1982 q 3$ & $1983 q 3$ \\
\hline Austria & $1992 q 2$ & 1993q1 & $2001 q 1$ & $2002 q 1$ & $1992 q 2$ & 1993q1 & $1996 q 2$ & 1997q1 & 1982q1 & $1982 q 2$ & $1990 q 3$ & $1991 q 4$ \\
\hline Austria & $1999 q 2$ & $2000 q 1$ & & & $1999 q 2$ & $2000 q 2$ & $2001 q 1$ & $2002 q 1$ & $1987 q 3$ & $1990 q 2$ & $2005 q 4$ & $2006 q 4$ \\
\hline Austria & $2003 q 4$ & $2005 q 4$ & & & & & $2007 q 2$ & $2009 q 4$ & 1996q1 & $1996 q 4$ & & \\
\hline Austria & & & & & & & & & $2005 q 1$ & $2005 q 3$ & & \\
\hline Canada & $1981 q 2$ & 1981q4 & $1982 q 1$ & $1983 q 1$ & $1981 q 2$ & $1981 q 4$ & $1982 q 1$ & $1983 q 2$ & $1980 q 1$ & $1980 q 3$ & $1980 q 4$ & 1982q1 \\
\hline Canada & $1996 q 4$ & 1997q3 & $1991 q 2$ & $1992 q 1$ & 1997q1 & $1997 q 3$ & $1995 q 2$ & 1996q1 & $1987 q 2$ & $1987 q 4$ & $1988 q 1$ & 1989q1 \\
\hline Canada & $2000 q 1$ & 2001q1 & $1995 q 2$ & 1996q1 & $2001 q 3$ & $2002 q 2$ & $2013 q 3$ & $2014 q 2$ & $2000 q 1$ & $2000 q 4$ & $2001 q 1$ & $2002 q^{3}$ \\
\hline Canada & $2006 q 2$ & $2007 q 1$ & $2008 q 4$ & $2009 q 2$ & $2009 q 4$ & $2010 q 2$ & & & $2013 q 2$ & $2014 q 1$ & $2008 q^{3}$ & $2009 q 3$ \\
\hline Denmark & $1985 q 4$ & $1986 q 2$ & $1986 q 3$ & $1987 q 2$ & $1985 q 4$ & $1986 q 2$ & $1986 q 3$ & $1987 q 2$ & $1985 q 4$ & $1986 q^{3}$ & $1992 q 4$ & 1993q1 \\
\hline Denmark & $2005 q 1$ & $2005 q 4$ & $1989 q 2$ & $1989 q 4$ & $1995 q 2$ & $1996 q 4$ & $1989 q 2$ & $1989 q 4$ & $1988 q 2$ & $1990 q 3$ & $1995 q 3$ & $1996 q 4$ \\
\hline Denmark & & & $1991 q 4$ & $1993 q 2$ & $2005 q 1$ & $2005 q 4$ & $1991 q 4$ & $1992 q 3$ & $1994 q 3$ & $1995 q 2$ & $2001 q 1$ & $2002 q 1$ \\
\hline Denmark & & & $1994 q 3$ & $1995 q 1$ & & & $1994 q 3$ & $1995 q 1$ & $1999 q 3$ & $2000 q 4$ & & \\
\hline Denmark & & & $2001 q 2$ & $2002 q 1$ & & & $2000 q 1$ & $2000 q 3$ & & & & \\
\hline Denmark & & & $2008 q 4$ & $2009 q 4$ & & & $2008 q 4$ & $2009 q 4$ & & & & \\
\hline Denmark & & & & & & & $2011 q 2$ & $2011 q 4$ & & & & \\
\hline Finland & $1984 q 3$ & $1985 q 1$ & $1985 q 4$ & $1986 q 2$ & $1984 q 3$ & $1985 q 1$ & $1985 q 4$ & $1986 q 3$ & 1981q1 & $1981 q 4$ & $1982 q 3$ & $1983 q 1$ \\
\hline Finland & 1987q1 & 1987q4 & 1991q1 & $1992 q 2$ & $1986 q 4$ & $1987 q 4$ & 1991q1 & $1992 q 2$ & $1986 q 2$ & $1987 q 3$ & $1991 q 4$ & $1992 q 2$ \\
\hline Finland & $1996 q 3$ & 1997q3 & $2001 q 1$ & $2001 q 4$ & $1996 q 3$ & $1997 q 3$ & $2005 q 1$ & $2005 q^{3}$ & $1992 q 3$ & $1994 q 3$ & 2001q1 & $2001 q 4$ \\
\hline Finland & $1998 q 4$ & 1999q1 & $2009 q 2$ & $2009 q 3$ & $2004 q 3$ & $2004 q 4$ & $2009 q 2$ & $2009 q 3$ & $1998 q 2$ & $1999 q 1$ & $2008 q 2$ & $2009 q 1$ \\
\hline Finland & $2004 q 3$ & $2004 q 4$ & $2012 q 3$ & $2013 q 3$ & $2011 q 3$ & $2011 q 4$ & $2012 q 3$ & $2013 q 3$ & $2014 q 1$ & $2014 q 4$ & & \\
\hline Finland & $2010 q 2$ & $2010 q 3$ & & & & & & & & & & \\
\hline Finland & $2011 q^{3}$ & $2011 q 4$ & & & & & & & & & & \\
\hline France & $1986 q 3$ & $1987 q 4$ & 1981q3 & $1982 q 2$ & $1986 q 4$ & $1988 q 1$ & $1981 q 3$ & $1982 q 2$ & 1985q1 & $1986 q 4$ & $1981 q 3$ & $1982 q 4$ \\
\hline France & 1989q1 & $1989 q 4$ & 1991q1 & 1992q1 & 1997q4 & $1998 q 3$ & 1991q1 & 1992q1 & $1989 q 3$ & $1990 q 3$ & $1993 q 1$ & $1993 q 2$ \\
\hline France & 1997q4 & $1998 q 3$ & $2001 q 3$ & $2002 q 3$ & 2001q1 & $2001 q 2$ & $2002 q 1$ & $2002 q 3$ & 1999q3 & $2000 q 3$ & $1994 q 3$ & $1995 q 2$ \\
\hline France & 2001q1 & $2001 q 2$ & $2008 q 1$ & $2009 q 3$ & & & $2008 q 1$ & $2009 q 3$ & $2005 q 3$ & $2006 q 2$ & $2001 q 3$ & $2002 q 2$ \\
\hline France & & & & & & & & & & & $2007 q 1$ & $2007 q 4$ \\
\hline Germany & 1980q1 & $1980 q 2$ & $1981 q 4$ & $1982 q 4$ & 1980q1 & $1980 q 2$ & $1981 q 4$ & $1982 q 4$ & $1986 q 1$ & $1986 q 4$ & $1980 q 2$ & 1981q1 \\
\hline Germany & 1986q1 & $1986 q 4$ & $1987 q 4$ & $1988 q 3$ & 1986q1 & $1986 q 3$ & $1987 q 4$ & $1988 q 3$ & $1988 q 4$ & 1990q1 & $1987 q 4$ & $1988 q^{3}$ \\
\hline Germany & $1989 q 2$ & 1990q1 & $1993 q 4$ & $1994 q 4$ & $1989 q 2$ & $1990 q 1$ & 1994q1 & $1994 q 4$ & 1997q1 & $1998 q 4$ & $1990 q 4$ & 1991q2 \\
\hline Germany & $1992 q 3$ & $1993 q 3$ & $2001 q 1$ & $2002 q 2$ & $1992 q 3$ & $1993 q 2$ & $2000 q 1$ & $2002 q 2$ & $2000 q 1$ & $2000 q 3$ & $2000 q 4$ & $2001 q 4$ \\
\hline Germany & $2005 q 1$ & $2005 q 4$ & $2008 q 2$ & $2009 q 3$ & $2003 q 1$ & $2003 q 2$ & $2008 q 4$ & $2009 q 3$ & 2007q1 & $2007 q 3$ & $2008 q 2$ & $2009 q 1$ \\
\hline Germany & $2007 q 2$ & $2008 q 1$ & & & $2004 q 3$ & $2005 q 3$ & & & & & & \\
\hline Germany & & & & & $2007 q 2$ & $2008 q 1$ & & & & & & \\
\hline Greece & $1989 q 4$ & 1991q1 & $1981 q 4$ & $1982 q 3$ & $1989 q 4$ & $1990 q 3$ & 1981q3 & 1982q1 & 1987q1 & $1988 q 4$ & $1981 q 4$ & $1982 q 3$ \\
\hline Greece & 1995q1 & $1995 q 2$ & 1992q1 & $1992 q 4$ & $1995 q 1$ & $1995 q 2$ & 1992q1 & $1992 q 2$ & $2000 q 2$ & $2001 q 2$ & $1998 q 1$ & $2000 q 1$ \\
\hline Greece & $1996 q 3$ & 1997q1 & $1995 q 3$ & $1996 q 2$ & $1996 q 3$ & 1997q1 & $1995 q 3$ & $1996 q 2$ & $2006 q 3$ & $2007 q 2$ & $2008 q 1$ & $2009 q 1$ \\
\hline Greece & $1998 q 2$ & 1999q1 & $1997 q 2$ & $1998 q 1$ & $2005 q 1$ & $2005 q 3$ & $1997 q 2$ & $1998 q 2$ & $2013 q 4$ & $2014 q 4$ & & \\
\hline Greece & $2002 q 2$ & $2003 q 1$ & $2005 q 4$ & $2006 q 4$ & $2007 q 1$ & $2008 q 3$ & $2005 q 4$ & $2006 q 4$ & & & & \\
\hline Greece & $2005 q 1$ & $2005 q 3$ & $2010 q 2$ & $2011 q 2$ & & & $2010 q 2$ & $2011 q 2$ & & & & \\
\hline Greece & $2007 q 1$ & $2007 q 4$ & & & & & & & & & & \\
\hline Iceland & 1987q1 & $1987 q 4$ & $1982 q 4$ & $1983 q 4$ & 1987q1 & $1987 q 4$ & $1982 q 4$ & $1983 q 3$ & 1990q1 & $1991 q 2$ & $1983 q 2$ & 1984q1 \\
\hline Iceland & $1995 q 4$ & $1996 q 4$ & $1989 q 2$ & 1990q1 & $1995 q 4$ & $1996 q 1$ & $1989 q 2$ & 1990q1 & 1996q1 & 1997q1 & $1999 q 4$ & $2000 q 3$ \\
\hline Iceland & $1998 q 3$ & $1999 q 4$ & $2001 q 2$ & $2002 q 1$ & $1998 q 3$ & $1999 q 4$ & 1993q3 & $1993 q 4$ & $2001 q 2$ & $2001 q 3$ & $2008 q 2$ & $2009 q 2$ \\
\hline Iceland & $2003 q 3$ & $2006 q 1$ & $2008 q 2$ & $2009 q 3$ & $2003 q 3$ & $2006 q 1$ & $2001 q 2$ & $2002 q 1$ & $2003 q 4$ & $2007 q 3$ & & \\
\hline Iceland & & & & & & & $2008 q 2$ & $2009 q 3$ & & & & \\
\hline
\end{tabular}


Table A6: Episodes of Capital Inflows (Continued)

\begin{tabular}{|c|c|c|c|c|c|c|c|c|c|c|c|c|}
\hline \multirow{3}{*}{ Country } & \multicolumn{4}{|c|}{ Total } & \multicolumn{4}{|c|}{ Debt } & \multicolumn{4}{|c|}{ Equity } \\
\hline & \multicolumn{2}{|c|}{ SURGES } & \multicolumn{2}{|c|}{ STOPS } & \multicolumn{2}{|c|}{ SURGES } & \multicolumn{2}{|c|}{ STOPS } & \multicolumn{2}{|c|}{ SURGES } & \multicolumn{2}{|c|}{ STOPS } \\
\hline & Start & End & Start & End & Start & End & Start & End & Start & End & Start & End \\
\hline & & & & & dvanced & conomie & & & & & & \\
\hline Ireland & $1986 q 4$ & $1987 q 3$ & 1991q3 & $1992 q 2$ & $1986 q 4$ & $1987 q 2$ & 1991q3 & $1992 q 2$ & 1987q2 & $1988 q 2$ & $1986 q 4$ & 1987q1 \\
\hline Ireland & $1989 q 3$ & $1990 q 2$ & $2008 q 2$ & $2009 q 3$ & $1992 q 3$ & $1993 q 4$ & $2008 q 2$ & $2009 q 4$ & 1990q1 & 1992q1 & $1993 q 4$ & $1994 q^{3}$ \\
\hline Ireland & $1992 q 3$ & $1993 q 4$ & & & $1995 q 3$ & $1996 q 4$ & & & $1996 q 4$ & $1999 q 2$ & $2001 q 2$ & $2001 q 4$ \\
\hline Ireland & $1995 q 3$ & $1996 q 3$ & & & $1997 q 4$ & $1998 q 3$ & & & $2006 q 3$ & $2007 q 2$ & $2004 q 2$ & $2005 q 1$ \\
\hline Ireland & 1997q4 & 1999q1 & & & $2003 q 1$ & $2004 q^{3}$ & & & & & $2008 q 2$ & $2009 q 2$ \\
\hline Ireland & $2003 q^{3}$ & $2004 q 2$ & & & 2007q1 & $2007 q^{3}$ & & & & & & \\
\hline Ireland & $2006 q 3$ & $2007 q 3$ & & & & & & & & & & \\
\hline Ireland & $2014 q 2$ & $2014 q 4$ & & & & & & & & & & \\
\hline Italy & $1990 q 3$ & 1991q1 & $1982 q 2$ & $1983 q 1$ & 1990q2 & 1991q1 & $1982 q 2$ & 1983q1 & 1987q3 & $1989 q 2$ & $1986 q 3$ & $1986 q 4$ \\
\hline Italy & $2002 q 4$ & $2003 q 4$ & 1991q4 & $1993 q 3$ & 1999q4 & $2000 q 1$ & 1991q4 & $1993 q 3$ & $1995 q 4$ & $1996 q 3$ & 1990q1 & $1990 q 2$ \\
\hline Italy & $2005 q 2$ & $2006 q 1$ & $2000 q 4$ & $2002 q 3$ & $2003 q 1$ & $2003 q^{3}$ & $2000 q 4$ & $2002 q 2$ & 2001q1 & $2001 q 3$ & 1991q3 & $1991 q 4$ \\
\hline Italy & $2010 q 4$ & $2011 q 3$ & & & $2005 q 1$ & $2005 q 4$ & & & $2005 q 4$ & $2006 q 3$ & $1994 q 4$ & 1995q1 \\
\hline Italy & & & & & $2010 q 4$ & $2011 q^{3}$ & & & & & $1999 q 2$ & $2000 q 1$ \\
\hline Italy & & & & & & & & & & & $2005 q 2$ & $2005 q^{3}$ \\
\hline Japan & $1986 q 2$ & $1987 q 3$ & 1990q4 & 1993q1 & $1986 q 3$ & $1987 q 4$ & 1982q4 & 1983q1 & $1988 q 3$ & $1989 q 3$ & $1984 q 2$ & $1985 q 1$ \\
\hline Japan & $1993 q 4$ & 1995q1 & 1998q1 & 1999q1 & 1993q4 & $1995 q 4$ & $1990 q 4$ & $1991 q 4$ & $1999 q 2$ & $2000 q 1$ & $1986 q 3$ & $1987 q 4$ \\
\hline Japan & $2009 q 4$ & 2011q1 & $2008 q 3$ & $2009 q 3$ & $2000 q 1$ & $2001 q 1$ & $1998 q 1$ & $1999 q 4$ & $2009 q 4$ & $2010 q 3$ & $2000 q 2$ & 2001q1 \\
\hline Japan & & & & & $2010 q 3$ & $2011 q 1$ & $2008 q 4$ & $2009 q 3$ & $2013 q 1$ & $2013 q 4$ & $2008 q 1$ & $2008 q 4$ \\
\hline Netherlands & $1997 q 4$ & $1998 q 4$ & 1981q1 & $1982 q 3$ & $1997 q 4$ & $1998 q^{3}$ & 1981q1 & $1982 q 3$ & $1986 q 2$ & $1987 q 2$ & 1981q4 & $1982 q^{3}$ \\
\hline Netherlands & $2005 q 2$ & $2006 q 2$ & $1990 q 4$ & $1991 q 4$ & $2006 q 4$ & $2007 q 3$ & 1991q1 & 1992q1 & $1988 q 3$ & $1989 q 2$ & $1987 q 3$ & $1988 q 2$ \\
\hline Netherlands & & & 2002q1 & $2002 q 4$ & $2010 q 2$ & $2010 q 4$ & $2007 q 4$ & $2009 q 3$ & $1995 q 4$ & $1996 q 4$ & $2014 q 2$ & $2014 q 4$ \\
\hline Netherlands & & & $2008 q 1$ & $2009 q 3$ & & & & & $1998 q 4$ & 1999q4 & & \\
\hline Netherlands & & & & & & & & & $2005 q 2$ & $2006 q 2$ & & \\
\hline Netherlands & & & & & & & & & $2012 q 1$ & $2013 q 1$ & & \\
\hline New Zealand & $1986 q 3$ & $1987 q 2$ & $1987 q 3$ & $1988 q 3$ & $1986 q 3$ & $1987 q 2$ & $1987 q 3$ & $1988 q 3$ & $1992 q 3$ & $1993 q 3$ & $1991 q 3$ & $1992 q 2$ \\
\hline New Zealand & $2000 q 2$ & 2001q1 & $1996 q 4$ & $1997 q 2$ & $1996 q 4$ & $1997 q 3$ & $1998 q 2$ & $1999 q 2$ & $2000 q 2$ & $2001 q 1$ & $1996 q 3$ & $1997 q 2$ \\
\hline New Zealand & $2006 q 3$ & $2007 q^{3}$ & $1998 q 3$ & $1999 q 2$ & $2000 q 4$ & $2001 q 4$ & $2008 q 2$ & $2009 q 2$ & $2006 q 4$ & $2007 q 2$ & $2001 q 2$ & $2002 q 2$ \\
\hline New Zealand & & & $2008 q 2$ & $2009 q 3$ & & & & & & & $2009 q 2$ & $2010 q 1$ \\
\hline Norway & $1982 q 3$ & $1982 q 4$ & $1983 q 3$ & $1983 q 4$ & $1982 q 3$ & $1983 q 2$ & 1981q1 & $1981 q 4$ & $1986 q 2$ & 1987q1 & $2001 q 4$ & $2003 q 1$ \\
\hline Norway & $1984 q 3$ & $1985 q 3$ & $1988 q 3$ & $1989 q 2$ & $1984 q 3$ & $1985 q^{3}$ & $1988 q 3$ & $1989 q 4$ & 1998q1 & $1998 q 3$ & $2008 q 1$ & $2008 q 4$ \\
\hline Norway & $1992 q 3$ & $1993 q 2$ & $1991 q 3$ & $1992 q 2$ & $1995 q 2$ & 1997q1 & $1997 q 4$ & 1998q1 & $2009 q 3$ & 2010q1 & & \\
\hline Norway & $1996 q 4$ & 1997q1 & 1997q4 & 1998q1 & $2002 q 2$ & $2003 q 2$ & $2001 q 3$ & $2002 q 1$ & & & & \\
\hline Norway & $2000 q 3$ & $2000 q 4$ & $2001 q 3$ & $2002 q 1$ & 2006q1 & $2007 q 1$ & $2007 q 4$ & $2009 q 4$ & & & & \\
\hline Norway & $2002 q 4$ & $2003 q 2$ & $2007 q 4$ & $2009 q 4$ & & & & & & & & \\
\hline Norway & $2005 q 4$ & 2007q1 & & & & & & & & & & \\
\hline Portugal & $1981 q 2$ & $1982 q 3$ & $1983 q 4$ & $1984 q 3$ & $1981 q 2$ & $1982 q 3$ & $1983 q 4$ & $1984 q 3$ & 1987q3 & $1990 q 3$ & $1992 q 4$ & $1993 q^{3}$ \\
\hline Portugal & $1988 q 4$ & $1990 q 2$ & 1992q3 & $1993 q 2$ & 1989q1 & $1989 q 4$ & 1992q3 & $1992 q 4$ & $1996 q 2$ & 1997q1 & 1999q1 & $1999 q 4$ \\
\hline Portugal & $1994 q 3$ & $1995 q^{3}$ & $2002 q 4$ & $2003 q 1$ & $1994 q 3$ & $1995 q^{3}$ & $2002 q 4$ & $2003 q 3$ & $2003 q 1$ & $2004 q 1$ & $2002 q 2$ & $2002 q 4$ \\
\hline Portugal & $2000 q 1$ & $2000 q 4$ & $2004 q 3$ & $2005 q 2$ & 2006q1 & $2006 q 2$ & $2005 q 1$ & $2005 q 2$ & & & $2007 q 3$ & $2008 q 2$ \\
\hline Portugal & $2003 q 4$ & $2004 q 2$ & 2010q3 & $2011 q 4$ & $2009 q 3$ & $2010 q 3$ & $2008 q 3$ & $2009 q 2$ & & & & \\
\hline Portugal & $2009 q 4$ & $2010 q 2$ & & & & & $2010 q 4$ & $2011 q 4$ & & & & \\
\hline Spain & 1987q1 & $1988 q 2$ & $1985 q 2$ & $1986 q 2$ & $1987 q 2$ & $1988 q 2$ & $1985 q 2$ & $1986 q 2$ & $1985 q 4$ & $1987 q 4$ & $1991 q 3$ & $1992 q 2$ \\
\hline Spain & 1990q4 & $1991 q 3$ & 1994q1 & $1995 q 1$ & $1990 q 4$ & $1991 q^{3}$ & 1994q1 & $1995 q 1$ & $1989 q 2$ & 1990q1 & 1994q1 & $1995 q 1$ \\
\hline Spain & $1993 q 2$ & $1993 q 4$ & $2001 q 2$ & $2002 q 2$ & $1993 q 2$ & $1993 q 4$ & $2001 q 3$ & $2002 q 2$ & 1998q1 & $1998 q 4$ & $2001 q 2$ & $2002 q^{3}$ \\
\hline Spain & $2000 q 3$ & 2001q1 & 2008q1 & $2009 q 4$ & $2003 q 3$ & $2004 q 2$ & $2007 q 3$ & $2009 q 3$ & $2000 q 2$ & $2001 q 1$ & & \\
\hline Spain & $2014 q 2$ & $2014 q 4$ & & & $2005 q 3$ & $2006 q 2$ & & & $2007 q 4$ & $2008 q 3$ & & \\
\hline Spain & & & & & $2014 q 2$ & $2014 q 4$ & & & & & & \\
\hline Sweden & $1985 q^{3}$ & $1987 q 3$ & $1983 q 4$ & $1984 q 3$ & $1985 q 3$ & $1987 q 3$ & 1991q1 & $1992 q 1$ & $1982 q 3$ & $1983 q 4$ & $1984 q 1$ & $1984 q 4$ \\
\hline Sweden & $1989 q 2$ & 1990q4 & 1991q1 & $1992 q 2$ & $1989 q 2$ & 1990q4 & $2002 q 1$ & $2002 q 4$ & 1991q1 & 1991q4 & $1987 q 2$ & $1988 q 1$ \\
\hline Sweden & $2004 q 4$ & $2005 q 3$ & 1997q1 & 1997q3 & & & $2008 q 4$ & $2009 q 3$ & $1998 q 2$ & $2000 q 1$ & 1992q1 & $1993 q 1$ \\
\hline Sweden & & & $2008 q 4$ & $2009 q 3$ & & & & & $2014 q 1$ & $2014 q 2$ & $2009 q 3$ & $2010 q 2$ \\
\hline United Kingdom & 1980q1 & $1980 q 2$ & $1991 q 3$ & 1992q1 & 1980q1 & $1980 q 2$ & $1991 q 3$ & 1992q1 & 1980q1 & $1980 q 4$ & 1981q3 & $1981 q 4$ \\
\hline United Kingdom & $1985 q 3$ & $1987 q 2$ & 1994q1 & $1994 q 4$ & $1985 q 4$ & $1987 q 2$ & 1998q1 & $1998 q 4$ & $1985 q 2$ & $1988 q 2$ & 1990q4 & 1992q1 \\
\hline United Kingdom & $1992 q 2$ & $1993 q 4$ & $2001 q 3$ & $2002 q 2$ & $1992 q 2$ & $1993 q 2$ & $2002 q 1$ & $2002 q 2$ & $1998 q 3$ & $1999 q 3$ & 2001q1 & $2002 q 1$ \\
\hline United Kingdom & $2000 q 3$ & $2000 q 4$ & 2008q1 & $2009 q 2$ & $2000 q 3$ & $2001 q 2$ & $2008 q 1$ & $2009 q 2$ & & & $2008 q 4$ & $2009 q 3$ \\
\hline United Kingdom & $2007 q 2$ & $2007 q 4$ & & & $2007 q 2$ & $2007 q 4$ & & & & & & \\
\hline United States & 1982q1 & $1982 q 3$ & $1982 q 4$ & $1983 q 3$ & 1982q1 & $1982 q 3$ & $1983 q 2$ & $1983 q 3$ & 1980q1 & 1981q1 & $1982 q 3$ & $1983 q 2$ \\
\hline United States & 1986q1 & $1986 q 4$ & $1989 q 4$ & $1990 q 4$ & $1993 q 4$ & $1994 q 3$ & $1989 q 2$ & 1990q1 & 1986q1 & $1987 q 3$ & $1987 q 4$ & $1988 q 4$ \\
\hline United States & $1993 q 3$ & $1994 q 3$ & $1997 q 4$ & 1999q1 & 1997q1 & $1997 q 3$ & 1997q4 & 1999q3 & $1993 q 2$ & 1994q1 & 1990q3 & 1991q1 \\
\hline United States & 1997q1 & $1997 q 3$ & $2001 q 3$ & $2002 q 2$ & $2004 q 2$ & $2004 q 4$ & $2007 q 3$ & $2009 q 2$ & $1999 q 2$ & $2000 q 1$ & $2001 q 3$ & $2002 q^{3}$ \\
\hline United States & $1999 q 4$ & $2000 q 3$ & $2007 q 3$ & $2009 q 2$ & $2006 q 4$ & $2007 q 2$ & & & & & $2008 q 3$ & $2009 q 3$ \\
\hline United States & $2006 q 4$ & $2007 q 2$ & & & & & & & & & & \\
\hline
\end{tabular}


Table A6: Episodes of Capital Inflows (Continued)

\begin{tabular}{|c|c|c|c|c|c|c|c|c|c|c|c|c|}
\hline \multirow{3}{*}{ Country } & \multicolumn{4}{|c|}{ Total } & \multicolumn{4}{|c|}{ Debt } & \multicolumn{4}{|c|}{ Equity } \\
\hline & \multicolumn{2}{|c|}{ SURGES } & \multicolumn{2}{|c|}{ STOPS } & \multicolumn{2}{|c|}{ SURGES } & \multicolumn{2}{|c|}{ STOPS } & \multicolumn{2}{|c|}{ SURGES } & \multicolumn{2}{|c|}{ STOPS } \\
\hline & Start & End & Start & End & Start & End & Start & End & Start & End & Start & End \\
\hline \multicolumn{13}{|c|}{ Emerging Economies } \\
\hline $\begin{array}{l}\text { Argentina } \\
\text { Argentina } \\
\text { Argentina } \\
\text { Argentina } \\
\text { Argentina }\end{array}$ & $1990 q 3$ & $1992 q 3$ & $\begin{array}{l}1982 q 4 \\
1989 q 2 \\
2000 q 4 \\
2008 q 2\end{array}$ & $\begin{array}{l}1983 q 1 \\
1990 q 2 \\
2002 q 2 \\
2009 q 3\end{array}$ & $1990 q 4$ & $1992 q 3$ & $\begin{array}{l}1982 q 4 \\
1988 q 4 \\
1999 q 1 \\
2001 q 3 \\
2008 q 2\end{array}$ & $\begin{array}{l}1983 q 1 \\
1990 q 3 \\
1999 q 3 \\
2002 q 2 \\
2009 q 3\end{array}$ & $\begin{array}{l}1990 q 4 \\
1992 q 4 \\
1999 q 2 \\
2008 q 1\end{array}$ & $\begin{array}{l}1991 q 3 \\
1994 q 2 \\
1999 q 4 \\
2008 q 3\end{array}$ & $\begin{array}{l}1982 q 1 \\
1987 q 2 \\
1998 q 3 \\
2008 q 4\end{array}$ & $\begin{array}{l}1982 q 4 \\
1988 q 1 \\
1999 q 1 \\
2010 q 1\end{array}$ \\
\hline Bangladesh & 1989q1 & $1989 q 4$ & $1982 q 4$ & $1983 q 3$ & 1989q1 & $1989 q 4$ & $1982 q 4$ & $1983 q 3$ & $1983 q 1$ & $1983 q 3$ & $1983 q 4$ & $1984 q 3$ \\
\hline Bangladesh & 1998q1 & $1998 q 3$ & $1991 q 3$ & 1992q1 & $2009 q 4$ & $2010 q 2$ & $1991 q 3$ & 1992q1 & $1986 q 3$ & $1987 q 3$ & $1985 q 4$ & $1986 q 2$ \\
\hline Bangladesh & $2003 q 4$ & $2004 q 1$ & $2010 q 3$ & $2011 q 2$ & $2012 q 2$ & $2013 q 1$ & 1999q1 & 1999q2 & $1992 q 2$ & $1994 q 4$ & $1995 q 3$ & $1997 q 2$ \\
\hline Bangladesh & $2005 q 1$ & $2005 q 2$ & & & & & $2002 q 4$ & $2003 q 1$ & 1997q3 & $1998 q 3$ & $2008 q 1$ & $2008 q^{3}$ \\
\hline Bangladesh & 2010q1 & $2010 q 2$ & & & & & $2005 q 4$ & $2006 q 1$ & $2003 q 3$ & $2004 q 3$ & $2009 q 3$ & 2010q1 \\
\hline Bangladesh & $2012 q 2$ & $2013 q 2$ & & & & & & & $2012 q 2$ & $2013 q 2$ & & \\
\hline Bolivia & 1996q1 & $1996 q 3$ & $1999 q 1$ & $2001 q 2$ & $2001 q 4$ & $2002 q 4$ & $1999 q 4$ & $2000 q 1$ & $1995 q 2$ & 1996q3 & $2000 q 4$ & $2001 q 3$ \\
\hline Bolivia & $1997 q 4$ & $1998 q 4$ & $2006 q 3$ & $2007 q 1$ & $2008 q 1$ & $2008 q 3$ & $2006 q 2$ & $2007 q 2$ & 1997q4 & $1998 \mathrm{q} 3$ & $2003 q 1$ & $2003 q 4$ \\
\hline Bolivia & $2007 q 2$ & $2008 q 4$ & $2014 q 3$ & $2014 q 4$ & & & $2014 q 3$ & $2014 q 4$ & $2006 q 4$ & $2007 q 3$ & $2014 q 2$ & $2014 q 4$ \\
\hline Bolivia & & & & & & & & & $2013 q 4$ & $2014 q 1$ & & \\
\hline Brazil & 1990q2 & 1991q1 & $1982 q 4$ & $1983 q 4$ & $1990 q 2$ & 1991q1 & $1982 q 4$ & $1983 q 4$ & $1987 q 4$ & $1989 q 1$ & $1980 q 4$ & $1981 q 2$ \\
\hline Brazil & $1992 q 2$ & $1992 q 3$ & $1994 q 4$ & $1995 q 2$ & $1995 q 3$ & 1996q1 & $1996 q 2$ & $1997 q 2$ & $1993 q 4$ & $1994 q 3$ & $1983 q 3$ & $1984 q 2$ \\
\hline Brazil & 1994q1 & $1994 q 3$ & 1999q1 & $1999 q 2$ & $2005 q 4$ & $2007 q 3$ & 1999q1 & $1999 q 3$ & 2007q1 & $2008 q 1$ & $1989 q 2$ & $1990 q 2$ \\
\hline Brazil & $1995 q 3$ & $1996 q 2$ & $2008 q 1$ & $2009 q 3$ & & & $2008 q 2$ & $2009 q 3$ & & & $1994 q 4$ & $1995 q 3$ \\
\hline Brazil & $2006 q 3$ & $2007 q 4$ & & & & & & & & & $2001 q 3$ & $2003 q 2$ \\
\hline Brazil & & & & & & & & & & & $2008 q 4$ & $2009 q 2$ \\
\hline Chile & $2005 q 4$ & $2006 q 3$ & $2000 q 2$ & 2001q1 & $2005 q 3$ & $2006 q 2$ & $2008 q 4$ & $2009 q 3$ & $1993 q 4$ & $1995 q 1$ & $1998 q 3$ & 1999q1 \\
\hline Chile & $2007 q 4$ & $2008 q 3$ & $2008 q 4$ & $2009 q 3$ & $2008 q 1$ & $2008 q 3$ & & & $1996 q 3$ & 1997q3 & $2000 q 2$ & $2000 q 4$ \\
\hline Chile & & & $2013 q 2$ & 2014q1 & & & & & $2007 q 4$ & $2008 q 1$ & $2013 q 2$ & 2014q1 \\
\hline Chile & & & & & & & & & $2011 q 4$ & $2012 q 3$ & & \\
\hline Colombia & $2005 q 4$ & $2006 q 3$ & 1998q1 & $1999 q 3$ & $2006 q 3$ & $2007 q 2$ & $1997 q 4$ & $1999 q 3$ & $2004 q 2$ & $2006 q 4$ & $1998 q 2$ & $1999 q 2$ \\
\hline Colombia & $2010 q 4$ & $2011 q 2$ & & & $2010 q 2$ & $2010 q 3$ & $2008 q 1$ & $2008 q 4$ & $2011 q 2$ & $2012 q 2$ & & \\
\hline Colombia & & & & & & & $2012 q 1$ & 2013q1 & & & & \\
\hline Croatia & $2002 q 4$ & $2003 q 4$ & $1998 q 4$ & $1999 q 2$ & $2002 q 4$ & $2003 q 4$ & $1998 q 4$ & 1999q1 & $1999 q 4$ & $2000 q 2$ & $1999 q 2$ & $1999 q 3$ \\
\hline Croatia & & & $2004 q 4$ & $2005 q 3$ & $2013 q 4$ & $2014 q 3$ & $2010 q 3$ & $2010 q 4$ & $2006 q 3$ & $2007 q 3$ & $2000 q 3$ & $2001 q 3$ \\
\hline Croatia & & & $2010 q 2$ & 2011q1 & & & $2012 q 1$ & $2012 q 2$ & $2014 q 2$ & $2014 q 4$ & $2009 q 4$ & $2011 q 2$ \\
\hline Czech Republic & $2002 q 3$ & $2003 q 1$ & $2008 q 4$ & $2009 q 3$ & $2004 q 2$ & $2005 q 1$ & $2005 q 4$ & $2006 q 3$ & & & $2003 q 2$ & $2004 q 1$ \\
\hline Czech Republic & & & & & $2007 q 3$ & $2008 q 3$ & $2008 q 4$ & $2009 q 3$ & & & & \\
\hline Estonia & 1997q4 & 1998q1 & $1998 q 2$ & $1999 q 3$ & 1997q4 & 1998q1 & $1998 q 2$ & $1999 q 3$ & $1998 q 4$ & $1999 q 2$ & $1999 q 3$ & $2000 q 3$ \\
\hline Estonia & $2003 q 1$ & $2005 q 1$ & $2008 q 1$ & $2009 q 3$ & $2004 q 2$ & $2005 q 1$ & $2008 q 2$ & $2009 q 4$ & $2003 q 3$ & $2004 q 1$ & $2008 q 1$ & $2009 q 3$ \\
\hline Estonia & 2007q1 & $2007 q 4$ & & & & & & & $2005 q 2$ & $2005 q 3$ & & \\
\hline Estonia & & & & & & & & & $2007 q 1$ & $2007 q 4$ & & \\
\hline Hungary & $2002 q 4$ & $2003 q 4$ & $1996 q 4$ & $1997 q 1$ & $2002 q 4$ & $2003 q 4$ & $1996 q 1$ & $1996 q 4$ & $1995 q 4$ & $1996 q 3$ & $2009 q 3$ & $2010 q 2$ \\
\hline Hungary & $2005 q 1$ & $2005 q 3$ & $2002 q 2$ & $2002 q 3$ & & & $2002 q 1$ & $2002 q 3$ & $2004 q 1$ & $2005 q 2$ & & \\
\hline Hungary & $2006 q 3$ & $2008 q 1$ & $2009 q 3$ & $2010 q 2$ & & & $2009 q 1$ & 2010q1 & $2006 q 1$ & $2008 q 1$ & & \\
\hline India & $1982 q 2$ & $1982 q 3$ & $1989 q 4$ & $1990 q 4$ & 1982q2 & $1982 q 3$ & $1989 q 4$ & $1990 q 4$ & 1991q1 & $1994 q 4$ & $2008 q 2$ & $2009 q 2$ \\
\hline India & $1984 q 1$ & $1985 q 2$ & $1991 q 3$ & 1992q1 & 1984q1 & $1985 q 2$ & $1991 q 3$ & 1992q1 & $2003 q 3$ & $2004 q 2$ & & \\
\hline India & 1987q1 & $1987 q 3$ & $2008 q 2$ & $2009 q 3$ & 1987q1 & $1987 q 3$ & $2008 q 2$ & $2009 q 3$ & $2006 q 4$ & $2008 q 1$ & & \\
\hline India & $1993 q 4$ & $1994 q 4$ & & & $1996 q 2$ & $1997 q 2$ & & & & & & \\
\hline India & 1996q2 & 1997q1 & & & $2004 q 4$ & $2005 q 3$ & & & & & & \\
\hline India & $2003 q 3$ & $2005 q 3$ & & & $2006 q 4$ & 2008q1 & & & & & & \\
\hline India & $2006 q 4$ & 2008q1 & & & & & & & & & & \\
\hline Indonesia & 1990q3 & $1991 q 2$ & $1997 q 4$ & $1998 q 3$ & 1991q1 & $1991 q 2$ & $1993 q 2$ & $1993 q 4$ & $1988 q 1$ & $1988 q 3$ & $1997 q 4$ & $1998 q 3$ \\
\hline Indonesia & $1995 q 2$ & $1996 q 2$ & $2006 q 4$ & $2007 q 1$ & $1995 q 4$ & 1996q1 & 1997q4 & $1998 q 3$ & $1990 q 3$ & $1991 q 2$ & $2006 q 3$ & $2007 q 2$ \\
\hline Indonesia & $2005 q 4$ & $2006 q 1$ & $2009 q 1$ & $2009 q 3$ & $2005 q 4$ & $2006 q 1$ & $2011 q 3$ & $2012 q 2$ & $1993 q 2$ & $1994 q 2$ & & \\
\hline Indonesia & $2009 q 4$ & $2010 q 4$ & $2012 q 1$ & $2012 q 2$ & $2009 q 4$ & $2010 q 3$ & & & $1995 q 2$ & $1996 q 2$ & & \\
\hline Indonesia & & & & & & & & & $2010 q 3$ & $2011 q 2$ & & \\
\hline Israel & $1989 q 3$ & $1990 q 3$ & $1983 q 4$ & $1984 q 4$ & $1989 q 3$ & $1990 q 3$ & $1983 q 4$ & $1984 q 2$ & $1980 q 4$ & $1982 q 2$ & $1984 q 2$ & $1985 q 1$ \\
\hline Israel & 1999q1 & $2000 q 1$ & $1988 q 3$ & $1989 q 2$ & $1999 q 2$ & $1999 q 4$ & $1988 q 3$ & $1989 q 2$ & $1983 q 2$ & $1984 q 1$ & $1988 q 4$ & $1989 q 2$ \\
\hline Israel & $2006 q 1$ & $2006 q 4$ & $1998 q 3$ & $1998 q 4$ & $2009 q 4$ & $2010 q 4$ & $2008 q 2$ & 2009q1 & $1989 q 3$ & $1990 q 3$ & 1998q1 & $1998 q 4$ \\
\hline Israel & 2012q4 & $2013 q 4$ & $2001 q 2$ & $2002 q 2$ & & & 2011q3 & $2012 q 3$ & $1995 q 2$ & 1996q1 & 2001q1 & $2002 q 2$ \\
\hline Israel & & & $2011 q 4$ & $2012 q 3$ & & & & & $1999 q 3$ & $2000 q 4$ & $2007 q 3$ & $2007 q 4$ \\
\hline Israel & & & & & & & & & $2006 q 1$ & $2006 q 4$ & & \\
\hline
\end{tabular}


Table A6: Episodes of Capital Inflows (Continued)

\begin{tabular}{|c|c|c|c|c|c|c|c|c|c|c|c|c|}
\hline \multirow{3}{*}{ Country } & \multicolumn{4}{|c|}{ Total } & \multicolumn{4}{|c|}{ Debt } & \multicolumn{4}{|c|}{ Equity } \\
\hline & \multicolumn{2}{|c|}{ SURGES } & \multicolumn{2}{|c|}{ STOPS } & \multicolumn{2}{|c|}{ SURGES } & \multicolumn{2}{|c|}{ STOPS } & \multicolumn{2}{|c|}{ SURGES } & \multicolumn{2}{|c|}{ STOPS } \\
\hline & Start & End & Start & End & Start & End & Start & End & Start & End & Start & End \\
\hline \multicolumn{13}{|c|}{ Emerging Economies } \\
\hline Jordan & $1991 q 2$ & $1992 q 1$ & $1992 q 2$ & $1993 q 3$ & $1991 q 2$ & 1992q1 & $1992 q 2$ & $1993 q 3$ & 1997q1 & 1998q1 & $1982 q 4$ & $1983 q^{3}$ \\
\hline Jordan & $2004 q 4$ & $2005 q 4$ & $2007 q 3$ & $2008 q 2$ & $2004 q 3$ & $2005 q 3$ & $2003 q 1$ & $2004 q 2$ & $2000 q 1$ & $2000 q 3$ & $2000 q 4$ & $2001 q 4$ \\
\hline Jordan & $2013 q 1$ & $2013 q 4$ & & & $2007 q 1$ & $2007 q 2$ & $2008 q 1$ & $2008 q 4$ & $2005 q 3$ & $2006 q 4$ & $2007 q 1$ & $2007 q 4$ \\
\hline Korea & $1988 q 1$ & 1989q1 & $1986 q 3$ & $1987 q 4$ & $1988 q 1$ & 1989q1 & $1986 q 3$ & $1987 q 4$ & $1981 q 4$ & $1982 q 2$ & 1990q3 & $1991 q 2$ \\
\hline Korea & $1994 q 3$ & $1995 q 4$ & $1997 q 2$ & $1998 \mathrm{q3}$ & $1994 q 3$ & $1995 q 3$ & 1997q3 & 1998q3 & $1985 q 1$ & $1985 q 2$ & $1994 q 4$ & $1995 q 2$ \\
\hline Korea & $2006 q 2$ & $2007 q 2$ & $2008 q 1$ & $2009 q 2$ & $2006 q 2$ & $2007 q 2$ & $2008 q 3$ & $2009 q 3$ & $1986 q 2$ & $1987 q 3$ & $2000 q 4$ & $2002 q 4$ \\
\hline Korea & $2009 q 3$ & $2010 q 2$ & & & & & & & 1988q3 & $1989 q 2$ & $2007 q 4$ & $2008 q 2$ \\
\hline Korea & & & & & & & & & 1992q1 & $1994 q 1$ & & \\
\hline Korea & & & & & & & & & 1996q1 & $1996 q 2$ & & \\
\hline Korea & & & & & & & & & $1999 q 2$ & $2000 q 3$ & & \\
\hline Korea & & & & & & & & & $2003 q 3$ & $2004 q 2$ & & \\
\hline Korea & & & & & & & & & $2009 q 1$ & $2010 q 1$ & & \\
\hline Latvia & $2003 q 3$ & $2005 q 1$ & $1998 q^{3}$ & $1999 q 2$ & $1999 q 4$ & $2000 q 2$ & $1998 q 4$ & 1999q1 & $2004 q 2$ & $2005 q^{3}$ & $2008 q 2$ & $2009 q 4$ \\
\hline Latvia & $2006 q 2$ & $2007 q 4$ & $2008 q^{3}$ & $2009 q 3$ & $2003 q 3$ & $2004 q 4$ & $2008 q 3$ & $2009 q 3$ & $2006 q 2$ & $2007 q 3$ & & \\
\hline Latvia & & & & & $2006 q 2$ & $2007 q 4$ & & & & & & \\
\hline Lithuania & $2004 q 2$ & $2004 q 3$ & $1999 q 2$ & $2000 q 1$ & $2003 q 3$ & $2004 q 2$ & $1998 q 4$ & 1999q3 & $1998 q 4$ & 1999q1 & 1999q2 & $2000 q 2$ \\
\hline Lithuania & $2005 q 4$ & 2008q1 & $2000 q 4$ & $2001 q 2$ & $2007 q 2$ & 2008q1 & $2008 q 2$ & $2009 q 4$ & $2006 q 4$ & $2007 q 3$ & 2009q1 & $2010 q 2$ \\
\hline Lithuania & & & $2008 q 2$ & $2009 q 4$ & & & & & $2011 q 1$ & $2011 q 3$ & & \\
\hline Mexico & $1989 q 2$ & $1991 q 2$ & $1994 q 4$ & $1995 q 4$ & $1989 q 2$ & $1990 q 4$ & $1994 q 2$ & $1995 q 4$ & $1988 q 3$ & 1992q1 & $1992 q 4$ & $1993 q 2$ \\
\hline Mexico & $2007 q 3$ & $2008 q 2$ & $2008 q 3$ & $2009 q 3$ & $1993 q 2$ & $1993 q 3$ & & & $1993 q 4$ & $1994 q 3$ & $1994 q 4$ & $1995 q 3$ \\
\hline Mexico & & & & & $2005 q 1$ & $2005 q 2$ & & & $2001 q 3$ & $2002 q 2$ & $2008 q 4$ & $2009 q 2$ \\
\hline Mexico & & & & & $2007 q 3$ & $2008 q 2$ & & & $2012 q 4$ & $2014 q 1$ & & \\
\hline Moldova & $2006 q 4$ & $2008 q^{3}$ & $2008 q 4$ & $2010 q 1$ & $2004 q 1$ & $2004 q^{3}$ & $2009 q 1$ & $2009 q 4$ & $2005 q 1$ & $2005 q 4$ & $2009 q 2$ & $2010 q 2$ \\
\hline Moldova & & & & & $2007 q 3$ & $2008 q 2$ & & & $2007 q 1$ & $2008 q 3$ & & \\
\hline Pakistan & $1985 q 3$ & $1986 q 2$ & $1994 q 4$ & $1995 q^{3}$ & $1985 q 3$ & $1986 q 4$ & 1991q4 & $1992 q 2$ & 1991q4 & $1992 q 4$ & $1982 q 3$ & $1983 q 3$ \\
\hline Pakistan & $1988 q 2$ & 1989q1 & $1997 q 2$ & $1999 q 2$ & $1988 q 2$ & 1989q1 & $1998 q 3$ & $1999 q 2$ & $1994 q 3$ & $1995 q 1$ & $1995 q 2$ & $1996 q 1$ \\
\hline Pakistan & $1992 q 4$ & $1993 q 3$ & $2008 q 2$ & $2009 q 2$ & $1992 q 3$ & $1993 q 3$ & $2008 q 2$ & $2009 q 2$ & $2002 q 1$ & $2003 q 2$ & $2007 q 4$ & $2008 q 4$ \\
\hline Pakistan & 2001q1 & $2001 q 4$ & & & $2001 q 1$ & $2001 q 4$ & $2010 q 3$ & $2010 q 4$ & $2004 q 4$ & $2007 q 3$ & & \\
\hline Pakistan & $2005 q 1$ & $2007 q^{3}$ & & & $2014 q 1$ & $2014 q 4$ & & & $2012 q 4$ & $2014 q 4$ & & \\
\hline Pakistan & $2013 q 1$ & $2014 q 4$ & & & & & & & & & & \\
\hline Peru & 1990q4 & $1992 q 3$ & $1983 q 3$ & $1984 q 3$ & $1990 q 4$ & $1992 q 3$ & $1983 q 3$ & $1984 q 3$ & 1992q4 & 1995q1 & $1982 q 4$ & $1983 q 3$ \\
\hline Peru & $1994 q 2$ & $1995 q 1$ & $1998 q 4$ & 1999q3 & 1997q3 & $1997 q 4$ & $1992 q 4$ & $1993 q 4$ & $2005 q 3$ & $2006 q 2$ & $1990 q 3$ & $1992 q 3$ \\
\hline Peru & $2006 q 4$ & $2008 q 2$ & $2008 q 3$ & $2009 q 3$ & $2006 q 3$ & 2008q1 & $1998 q 4$ & $1999 q 3$ & $2007 q 3$ & $2008 q 2$ & 2009q1 & $2009 q 4$ \\
\hline Peru & & & $2013 q 4$ & $2014 q 3$ & & & $2005 q 2$ & $2006 q 2$ & $2013 q 4$ & $2014 q 3$ & & \\
\hline Peru & & & & & & & $2008 q 4$ & $2009 q 3$ & & & & \\
\hline Philippines & $1994 q 2$ & $1994 q 3$ & $1983 q 2$ & $1984 q 2$ & $1996 q 1$ & 1997q1 & $1983 q 2$ & $1984 q 2$ & $1986 q 4$ & 1989q1 & $1989 q 2$ & $1990 q 2$ \\
\hline Philippines & 1996q1 & 1997q1 & 1992q1 & $1992 q 2$ & 2007q1 & $2007 q 4$ & 1997q2 & 1998q4 & $1993 q 4$ & $1994 q 3$ & $1997 q 2$ & 1998q1 \\
\hline Philippines & $2005 q 2$ & $2005 q 4$ & $1997 q 2$ & $1998 q 3$ & & & $2006 q 2$ & $2006 q 4$ & 1996q1 & 1997q1 & $2007 q 4$ & $2009 q 1$ \\
\hline Philippines & $2006 q 4$ & $2007 q 3$ & $2006 q 1$ & $2006 q 3$ & & & $2008 q 1$ & $2009 q 1$ & $2005 q 1$ & $2005 q 4$ & & \\
\hline Philippines & & & $2007 q 4$ & $2009 q 1$ & & & & & $2006 q 4$ & $2007 q 3$ & & \\
\hline Poland & $2003 q 4$ & $2004 q 4$ & $1996 q 4$ & 1997q1 & $1997 q 2$ & 1998q2 & $1996 q 2$ & 1997q1 & 1991q1 & $1994 q 2$ & $2001 q 4$ & $2002 q 3$ \\
\hline Poland & $2007 q 1$ & $2008 q 2$ & $2001 q 4$ & $2002 q 3$ & $2003 q 4$ & $2004 q 3$ & $2001 q 4$ & $2002 q 3$ & $1995 q 3$ & $1996 q 3$ & $2008 q 3$ & $2009 q 3$ \\
\hline Poland & & & $2008 q 3$ & $2009 q 3$ & $2007 q 2$ & $2008 q 2$ & $2008 q^{3}$ & $2009 q 3$ & $2004 q 1$ & $2005 q 1$ & & \\
\hline Poland & & & & & & & & & $2006 q 4$ & $2007 q 3$ & & \\
\hline Poland & & & & & & & & & $2014 q 3$ & $2014 q 4$ & & \\
\hline Romania & $1996 q 4$ & $1997 q 3$ & $2008 q 3$ & $2010 q 1$ & $1996 q 4$ & $1997 q 3$ & $2008 q 3$ & $2009 q 4$ & $1997 q 2$ & $1998 q 2$ & 1999q4 & $2000 q^{3}$ \\
\hline Romania & $2000 q 4$ & $2001 q 2$ & & & $2004 q 4$ & $2005 q 4$ & & & $2004 q 1$ & $2005 q 1$ & $2007 q 3$ & $2008 q^{3}$ \\
\hline Romania & $2004 q 1$ & $2005 q 3$ & & & $2007 q 1$ & $2008 q 2$ & & & $2006 q 4$ & $2007 q 2$ & $2009 q 2$ & $2010 q 2$ \\
\hline Romania & $2006 q 4$ & $2007 q 4$ & & & & & & & & & & \\
\hline Russia & $2007 q 1$ & $2008 q 1$ & $2008 q 4$ & $2009 q 3$ & $2007 q 2$ & 2008q1 & $2006 q^{3}$ & $2006 q 4$ & $2002 q 4$ & $2003 q^{3}$ & $2008 q 4$ & $2009 q 4$ \\
\hline Russia & & & $2014 q 1$ & $2014 q 4$ & & & $2008 q 2$ & $2009 q 3$ & $2004 q 4$ & $2005 q^{3}$ & $2013 q 1$ & $2013 q^{3}$ \\
\hline Russia & & & & & & & $2014 q 1$ & $2014 q 4$ & $2006 q 4$ & $2007 q 2$ & & \\
\hline Russia & & & & & & & & & $2007 q 4$ & $2008 q 1$ & & \\
\hline Russia & & & & & & & & & $2013 q 4$ & $2014 q 4$ & & \\
\hline Singapore & $1995 q 2$ & 1996q1 & $1997 q 4$ & $1998 q 4$ & $1997 q 1$ & $1997 q 3$ & $1997 q 4$ & $1998 q 4$ & $1995 q 1$ & $1996 q 2$ & $2002 q 3$ & $2003 q 2$ \\
\hline Singapore & 1997q1 & $1997 q 3$ & $2008 q 1$ & $2009 q 2$ & $2006 q 4$ & $2008 q 1$ & $2008 q 4$ & $2009 q 4$ & $2003 q 3$ & $2004 q 4$ & $2008 q 2$ & $2009 q 1$ \\
\hline Singapore & $2006 q 4$ & $2007 q 4$ & & & $2013 q 3$ & $2013 q 4$ & $2012 q 1$ & $2012 q 3$ & & & $2014 q 3$ & $2014 q 4$ \\
\hline Slovakia & $2004 q 3$ & $2005 q 2$ & $1998 q 4$ & $1999 q 4$ & $2005 q 1$ & $2005 q^{3}$ & $1998 q 4$ & 1999q4 & $2000 q 3$ & $2001 q 2$ & $2003 q 2$ & $2004 q 2$ \\
\hline Slovakia & $2013 q 2$ & $2014 q 1$ & $2006 q 1$ & $2006 q 4$ & $2013 q 2$ & $2014 q 1$ & $2005 q 4$ & $2006 q 4$ & $2002 q 3$ & $2003 q 1$ & $2009 q 2$ & $2010 q 1$ \\
\hline Slovakia & & & 2010q1 & $2010 q 4$ & & & $2010 q 2$ & $2010 q 4$ & $2011 q 4$ & $2012 q 2$ & & \\
\hline
\end{tabular}


Table A6: Episodes of Capital Inflows (Continued)

\begin{tabular}{|c|c|c|c|c|c|c|c|c|c|c|c|c|}
\hline \multirow{3}{*}{ Country } & \multicolumn{4}{|c|}{ Total } & \multicolumn{4}{|c|}{ Debt } & \multicolumn{4}{|c|}{ Equity } \\
\hline & \multicolumn{2}{|c|}{ SURGES } & \multicolumn{2}{|c|}{ STOPS } & \multicolumn{2}{|c|}{ SURGES } & \multicolumn{2}{|c|}{ STOPS } & \multicolumn{2}{|c|}{ SURGES } & \multicolumn{2}{|c|}{ STOPS } \\
\hline & Start & End & Start & End & Start & End & Start & End & Start & End & Start & End \\
\hline \multicolumn{13}{|c|}{ Emerging Economies } \\
\hline $\begin{array}{l}\text { Slovenia } \\
\text { Slovenia } \\
\text { Slovenia }\end{array}$ & $\begin{array}{l}2002 q 3 \\
2007 q 1\end{array}$ & $\begin{array}{l}2003 q 3 \\
2007 q 4\end{array}$ & $\begin{array}{l}1997 q 4 \\
2008 q 3\end{array}$ & $\begin{array}{l}1998 q 4 \\
2009 q 3\end{array}$ & $\begin{array}{l}2003 q 1 \\
2004 q 4 \\
2007 q 1 \\
\end{array}$ & $\begin{array}{l}2003 q 3 \\
2006 q 2 \\
2007 q 4 \\
\end{array}$ & $2008 q 3$ & $2009 q 3$ & 2001q1 & $2003 q 1$ & $\begin{array}{l}2003 q 2 \\
2009 q 1\end{array}$ & $\begin{array}{l}2004 q 2 \\
2010 q 1\end{array}$ \\
\hline $\begin{array}{l}\text { South Africa } \\
\text { South Africa } \\
\text { South Africa } \\
\text { South Africa } \\
\text { South Africa }\end{array}$ & $\begin{array}{l}1994 q 3 \\
1997 q 2 \\
2003 q 4\end{array}$ & $\begin{array}{l}1995 q 4 \\
1998 q 1 \\
2006 q 2\end{array}$ & $\begin{array}{l}1998 q 2 \\
2008 q 3\end{array}$ & $\begin{array}{l}1999 q 2 \\
2009 q 2\end{array}$ & $\begin{array}{l}1991 q 3 \\
1997 q 1 \\
2003 q 3 \\
2006 q 3 \\
2009 q 4\end{array}$ & $\begin{array}{l}1992 q 3 \\
1997 q 4 \\
2004 q 1 \\
2007 q 1 \\
2010 q 3\end{array}$ & $\begin{array}{l}1993 q 2 \\
1998 q 1 \\
2008 q 2\end{array}$ & $\begin{array}{l}1993 q 4 \\
1999 q 2 \\
2009 q 3\end{array}$ & $\begin{array}{l}1992 q 3 \\
1995 q 2 \\
1997 q 2 \\
2004 q 1\end{array}$ & $\begin{array}{l}1993 q 3 \\
1995 q 4 \\
1998 q 2 \\
2006 q 2\end{array}$ & $\begin{array}{l}1991 q 3 \\
2007 q 1\end{array}$ & $\begin{array}{l}1992 q 2 \\
2007 q 2\end{array}$ \\
\hline $\begin{array}{l}\text { Sri Lanka } \\
\text { Sri Lanka } \\
\text { Sri Lanka } \\
\text { Sri Lanka } \\
\text { Sri Lanka } \\
\text { Sri Lanka }\end{array}$ & $\begin{array}{l}1982 q 3 \\
1989 q 3 \\
2011 q 1\end{array}$ & $\begin{array}{l}1983 q 2 \\
1990 q 3 \\
2013 q 2\end{array}$ & $\begin{array}{l}1983 q 3 \\
1994 q 2 \\
1998 q 3 \\
2001 q 2 \\
2008 q 1 \\
2010 q 3\end{array}$ & $\begin{array}{l}1984 q 4 \\
1994 q 3 \\
1999 q 1 \\
2002 q 1 \\
2008 q 2 \\
2010 q 4\end{array}$ & $\begin{array}{l}1982 q 4 \\
1989 q 3 \\
1994 q 4 \\
2000 q 1 \\
2010 q 1 \\
2011 q 2\end{array}$ & $\begin{array}{l}1983 q 2 \\
1990 q 3 \\
1995 q 2 \\
2000 q 4 \\
2010 q 2 \\
2013 q 2\end{array}$ & $\begin{array}{l}1983 q 3 \\
1994 q 1 \\
2001 q 1 \\
2007 q 4\end{array}$ & $\begin{array}{l}1984 q 4 \\
1994 q 3 \\
2002 q 1 \\
2008 q 2\end{array}$ & $\begin{array}{l}1987 q 3 \\
1992 q 2 \\
1997 q 3 \\
2006 q 3 \\
2011 q 3\end{array}$ & $\begin{array}{l}1988 q 2 \\
1994 q 1 \\
1998 q 2 \\
2007 q 2 \\
2012 q 4\end{array}$ & $\begin{array}{l}1989 q 1 \\
1994 q 4 \\
2009 q 4\end{array}$ & $\begin{array}{l}1989 q 4 \\
1995 q 4 \\
2010 q 4\end{array}$ \\
\hline $\begin{array}{l}\text { Taiwan } \\
\text { Taiwan } \\
\text { Taiwan } \\
\text { Taiwan } \\
\text { Taiwan } \\
\text { Taiwan } \\
\text { Taiwan } \\
\end{array}$ & $\begin{array}{l}1986 q 4 \\
1999 q 2 \\
2003 q 3 \\
2009 q 3\end{array}$ & $\begin{array}{l}1987 q 2 \\
2000 q 2 \\
2004 q 2 \\
2010 q 3\end{array}$ & $\begin{array}{l}1988 q 2 \\
2001 q 1 \\
2005 q 1 \\
2008 q 4\end{array}$ & $\begin{array}{l}1989 q 1 \\
2001 q 2 \\
2005 q 2 \\
2009 q 2\end{array}$ & $\begin{array}{l}1986 q 4 \\
1996 q 3 \\
2002 q 1 \\
2004 q 1\end{array}$ & $\begin{array}{l}1987 q 2 \\
1997 q 3 \\
2002 q 4 \\
2004 q 2\end{array}$ & $\begin{array}{l}1988 q 2 \\
1995 q 4 \\
2005 q 1 \\
2009 q 1\end{array}$ & $\begin{array}{l}1989 q 1 \\
1996 q 2 \\
2005 q 3 \\
2009 q 3\end{array}$ & $\begin{array}{l}1987 q 3 \\
1989 q 2 \\
1993 q 2 \\
1995 q 4 \\
1999 q 1 \\
2003 q 3 \\
2009 q 2 \\
\end{array}$ & $\begin{array}{l}1988 q 1 \\
1990 q 1 \\
1994 q 3 \\
1996 q 3 \\
2000 q 2 \\
2004 q 2 \\
2010 q 2\end{array}$ & $\begin{array}{l}1988 q 2 \\
1994 q 4 \\
1997 q 2 \\
2007 q 4\end{array}$ & $\begin{array}{l}1989 q 1 \\
1995 q 3 \\
1998 q 1 \\
2009 q 1\end{array}$ \\
\hline $\begin{array}{l}\text { Thailand } \\
\text { Thailand } \\
\text { Thailand } \\
\text { Thailand } \\
\text { Thailand } \\
\text { Thailand } \\
\end{array}$ & $\begin{array}{l}1987 q 4 \\
1995 q 2 \\
2004 q 3\end{array}$ & $\begin{array}{l}1990 q 2 \\
1996 q 1 \\
2006 q 1\end{array}$ & $\begin{array}{l}1992 q 1 \\
1996 q 2 \\
2007 q 1 \\
2008 q 3\end{array}$ & $\begin{array}{l}1992 q 4 \\
1998 q 2 \\
2007 q 4 \\
2009 q 3\end{array}$ & $\begin{array}{l}1988 q 2 \\
1995 q 2 \\
2004 q 3 \\
2009 q 4\end{array}$ & $\begin{array}{l}1991 q 4 \\
1996 q 1 \\
2005 q 2 \\
2011 q 1\end{array}$ & $\begin{array}{l}1982 q 1 \\
1986 q 3 \\
1992 q 1 \\
1996 q 2 \\
2007 q 1 \\
2008 q 4 \\
\end{array}$ & $\begin{array}{l}1982 q 2 \\
1986 q 4 \\
1993 q 1 \\
1998 q 2 \\
2007 q 4 \\
2009 q 3 \\
\end{array}$ & $\begin{array}{l}1986 q 4 \\
1997 q 3 \\
2003 q 3 \\
2005 q 1 \\
2012 q 4\end{array}$ & $\begin{array}{l}1990 q 2 \\
1998 q 2 \\
2004 q 2 \\
2006 q 1 \\
2013 q 1\end{array}$ & $\begin{array}{l}1985 q 4 \\
1990 q 3 \\
2008 q 2\end{array}$ & $\begin{array}{l}1986 q 1 \\
1991 q 4 \\
2009 q 2\end{array}$ \\
\hline \begin{tabular}{|l|} 
Turkey \\
Turkey \\
Turkey \\
Turkey \\
Turkey \\
\end{tabular} & $\begin{array}{l}1990 q 1 \\
1992 q 3 \\
2000 q 1\end{array}$ & $\begin{array}{l}1990 q 4 \\
1993 q 4 \\
2000 q 3\end{array}$ & $\begin{array}{l}1994 q 1 \\
2000 q 4 \\
2007 q 4\end{array}$ & $\begin{array}{l}1995 q 1 \\
2001 q 4 \\
2009 q 4\end{array}$ & $\begin{array}{l}1990 q 1 \\
1992 q 3 \\
2000 q 1 \\
2010 q 1\end{array}$ & $\begin{array}{l}1990 q 4 \\
1993 q 4 \\
2000 q 3 \\
2011 q 2\end{array}$ & $\begin{array}{l}1994 q 1 \\
2000 q 4 \\
2007 q 3 \\
2008 q 4\end{array}$ & $\begin{array}{l}1995 q 1 \\
2001 q 4 \\
2008 q 1 \\
2009 q 4\end{array}$ & $\begin{array}{l}1999 q 3 \\
2001 q 2 \\
2003 q 3\end{array}$ & $\begin{array}{l}2000 q 3 \\
2001 q 4 \\
2006 q 3\end{array}$ & $\begin{array}{l}1991 q 2 \\
1993 q 2 \\
1995 q 1 \\
2002 q 1 \\
2008 q 1\end{array}$ & $\begin{array}{l}1991 q 3 \\
1993 q 3 \\
1995 q 4 \\
2003 q 2 \\
2010 q 1\end{array}$ \\
\hline $\begin{array}{l}\text { Ukraine } \\
\text { Ukraine }\end{array}$ & $2004 q 1$ & $2008 q 2$ & $2008 q 3$ & $2010 q 1$ & $\begin{array}{l}2004 q 1 \\
2006 q 4\end{array}$ & $\begin{array}{l}2005 q 2 \\
2008 q 1\end{array}$ & $2008 q 4$ & $2010 q 1$ & $\begin{array}{l}2003 q 2 \\
2005 q 4\end{array}$ & $\begin{array}{l}2004 q 2 \\
2006 q 3\end{array}$ & $2014 q 1$ & $2014 q 4$ \\
\hline $\begin{array}{l}\text { Venezuela } \\
\text { Venezuela } \\
\text { Venezuela }\end{array}$ & $\begin{array}{l}1996 q 3 \\
2005 q 1 \\
2007 q 1\end{array}$ & $\begin{array}{l}1998 q 1 \\
2005 q 4 \\
2008 q 1\end{array}$ & $\begin{array}{l}2006 q 1 \\
2012 q 2\end{array}$ & $\begin{array}{l}2006 q 4 \\
2012 q 3\end{array}$ & $\begin{array}{l}2005 q 1 \\
2007 q 1\end{array}$ & $\begin{array}{l}2005 q 4 \\
2008 q 1\end{array}$ & $\begin{array}{l}2006 q 1 \\
2012 q 1\end{array}$ & $\begin{array}{l}2006 q 4 \\
2012 q 3\end{array}$ & $1996 q 2$ & 1998q1 & $\begin{array}{l}1998 q 2 \\
2009 q 2\end{array}$ & $\begin{array}{l}1999 q 2 \\
2010 q 1\end{array}$ \\
\hline
\end{tabular}

Notes: "Surges" and "stops" are identified following Forbes and Warnock (2012a and 2012b). Normal episode refers to the absence of either extreme episode. Dating of extreme episodes following the identification method discussed in Section 4. 
Appendix 4: Transitional Likelihoods and State-Dependence Variables

Table A7: Transitional Likelihoods, Total Gross Inflows

\begin{tabular}{|c|c|c|c|c|c|c|c|c|c|}
\hline Country & $\begin{array}{c}\text { Normal to } \\
\text { Normal }\end{array}$ & $\begin{array}{c}\text { Normal to } \\
\text { Surge }\end{array}$ & $\begin{array}{c}\text { Normal to } \\
\text { Stop }\end{array}$ & $\begin{array}{l}\text { Surge to } \\
\text { Normal }\end{array}$ & $\begin{array}{l}\text { Surge to } \\
\text { Surge }\end{array}$ & $\begin{array}{c}\text { Surge to } \\
\text { Stop }\end{array}$ & $\begin{array}{l}\text { Stop to } \\
\text { Normal }\end{array}$ & $\begin{array}{l}\text { Stop to } \\
\text { Surge }\end{array}$ & $\begin{array}{c}\text { Stop to } \\
\text { Stop }\end{array}$ \\
\hline \multicolumn{10}{|c|}{ Advanced Economies } \\
\hline Australia & 90.24 & 8.54 & 1.22 & 15.15 & 75.76 & 9.09 & 12.50 & 4.17 & 83.33 \\
\hline Austria & 94.55 & 3.64 & 1.82 & 21.05 & 78.95 & 0.00 & 20.00 & 0.00 & 80.00 \\
\hline Canada & 93.46 & 3.74 & 2.80 & 18.75 & 75.00 & 6.25 & 25.00 & 0.00 & 75.00 \\
\hline Denmark & 93.20 & 1.94 & 4.85 & 14.29 & 71.43 & 14.29 & 23.08 & 0.00 & 76.92 \\
\hline Finland & 87.50 & 7.29 & 5.21 & 35.00 & 65.00 & 0.00 & 25.00 & 0.00 & 75.00 \\
\hline France & 92.93 & 4.04 & 3.03 & 18.75 & 75.00 & 6.25 & 19.05 & 0.00 & 80.95 \\
\hline Germany & 91.11 & 5.56 & 3.33 & 17.39 & 73.91 & 8.70 & 19.23 & 0.00 & 80.77 \\
\hline Greece & 92.50 & 5.00 & 2.50 & 15.38 & 73.08 & 11.54 & 11.54 & 11.54 & 76.92 \\
\hline Iceland & 90.80 & 4.60 & 4.60 & 15.38 & 84.62 & 0.00 & 21.05 & 0.00 & 78.95 \\
\hline Ireland & 87.88 & 9.09 & 3.03 & 19.44 & 80.56 & 0.00 & 10.00 & 10.00 & 80.00 \\
\hline Italy & 92.78 & 3.09 & 4.12 & 25.00 & 75.00 & 0.00 & 11.54 & 3.85 & 84.62 \\
\hline Japan & 94.44 & 2.22 & 3.33 & 16.67 & 83.33 & 0.00 & 10.00 & 5.00 & 85.00 \\
\hline Netherlands & 94.34 & 1.89 & 3.77 & 20.00 & 80.00 & 0.00 & 17.39 & 0.00 & 82.61 \\
\hline New Zealand & 92.94 & 3.53 & 3.53 & 15.38 & 76.92 & 7.69 & 22.22 & 0.00 & 77.78 \\
\hline Norway & 86.36 & 6.82 & 6.82 & 29.17 & 70.83 & 0.00 & 20.83 & 4.17 & 75.00 \\
\hline Portugal & 89.77 & 6.82 & 3.41 & 14.29 & 78.57 & 7.14 & 25.00 & 0.00 & 75.00 \\
\hline Spain & 92.63 & 5.26 & 2.11 & 11.11 & 77.78 & 11.11 & 17.39 & 0.00 & 82.61 \\
\hline Sweden & 93.94 & 3.03 & 3.03 & 10.00 & 85.00 & 5.00 & 23.53 & 0.00 & 76.47 \\
\hline United Kingom & 95.00 & 3.00 & 2.00 & 13.64 & 77.27 & 9.09 & 17.65 & 5.88 & 76.47 \\
\hline United States & 91.11 & 6.67 & 2.22 & 13.64 & 72.73 & 13.64 & 18.52 & 0.00 & 81.48 \\
\hline \multicolumn{10}{|c|}{ Emerging Economies } \\
\hline Argentina & 96.12 & 0.00 & 3.88 & 11.11 & 88.89 & 0.00 & 15.00 & 5.00 & 80.00 \\
\hline Bangladesh & 92.31 & 5.77 & 1.92 & 29.41 & 64.71 & 5.88 & 27.27 & 0.00 & 72.73 \\
\hline Bolivia & 92.73 & 3.64 & 3.64 & 13.33 & 80.00 & 6.67 & 7.14 & 7.14 & 85.71 \\
\hline Brazil & 94.00 & 4.00 & 2.00 & 15.79 & 73.68 & 10.53 & 17.65 & 5.88 & 76.47 \\
\hline Chile & 94.12 & 2.94 & 2.94 & 12.50 & 75.00 & 12.50 & 25.00 & 0.00 & 75.00 \\
\hline Colombia & 94.44 & 3.70 & 1.85 & 28.57 & 71.43 & 0.00 & 14.29 & 0.00 & 85.71 \\
\hline Croatia & 93.75 & 2.08 & 4.17 & 20.00 & 80.00 & 0.00 & 27.27 & 0.00 & 72.73 \\
\hline Czech Republic & 96.49 & 1.75 & 1.75 & 33.33 & 66.67 & 0.00 & 25.00 & 0.00 & 75.00 \\
\hline Estonia & 95.00 & 5.00 & 0.00 & 6.67 & 80.00 & 13.33 & 15.38 & 0.00 & 84.62 \\
\hline Hungary & 90.74 & 3.70 & 5.56 & 20.00 & 80.00 & 0.00 & 25.00 & 12.50 & 62.50 \\
\hline India & 89.66 & 8.05 & 2.30 & 17.14 & 80.00 & 2.86 & 21.43 & 0.00 & 78.57 \\
\hline Indonesia & 91.76 & 3.53 & 4.71 & 25.00 & 75.00 & 0.00 & 27.27 & 9.09 & 63.64 \\
\hline Israel & 94.00 & 1.00 & 5.00 & 21.05 & 78.95 & 0.00 & 10.00 & 15.00 & 75.00 \\
\hline Jordan & 96.19 & 2.86 & 0.95 & 15.38 & 76.92 & 7.69 & 20.00 & 0.00 & 80.00 \\
\hline Korea & 94.68 & 2.13 & 3.19 & 20.00 & 80.00 & 0.00 & 5.56 & 11.11 & 83.33 \\
\hline Latvia & 92.86 & 4.76 & 2.38 & 14.29 & 85.71 & 0.00 & 25.00 & 0.00 & 75.00 \\
\hline Lithuania & 89.47 & 5.26 & 5.26 & 8.33 & 83.33 & 8.33 & 21.43 & 0.00 & 78.57 \\
\hline Mexico & 96.91 & 2.06 & 1.03 & 7.69 & 84.62 & 7.69 & 20.00 & 0.00 & 80.00 \\
\hline Moldova & 97.83 & 2.17 & 0.00 & 0.00 & 87.50 & 12.50 & 16.67 & 0.00 & 83.33 \\
\hline Pakistan & 88.75 & 7.50 & 3.75 & 14.71 & 85.29 & 0.00 & 16.67 & 0.00 & 83.33 \\
\hline Peru & 93.41 & 3.30 & 3.30 & 10.53 & 84.21 & 5.26 & 22.22 & 0.00 & 77.78 \\
\hline Philippines & 94.57 & 3.26 & 2.17 & 7.14 & 71.43 & 21.43 & 18.18 & 4.55 & 77.27 \\
\hline Poland & 94.59 & 2.70 & 2.70 & 9.09 & 81.82 & 9.09 & 27.27 & 0.00 & 72.73 \\
\hline Romania & 91.30 & 6.52 & 2.17 & 21.05 & 78.95 & 0.00 & 14.29 & 0.00 & 85.71 \\
\hline Russia & 93.75 & 2.08 & 4.17 & 20.00 & 80.00 & 0.00 & 14.29 & 0.00 & 85.71 \\
\hline Singapore & 95.65 & 4.35 & 0.00 & 8.33 & 75.00 & 16.67 & 18.18 & 0.00 & 81.82 \\
\hline Slovakia & 90.70 & 4.65 & 4.65 & 25.00 & 75.00 & 0.00 & 23.08 & 0.00 & 76.92 \\
\hline Slovenia & 93.88 & 4.08 & 2.04 & 22.22 & 77.78 & 0.00 & 20.00 & 0.00 & 80.00 \\
\hline SouthAfrica & 93.94 & 4.55 & 1.52 & 9.52 & 85.71 & 4.76 & 22.22 & 0.00 & 77.78 \\
\hline Sri Lanka & 93.41 & 1.10 & 5.49 & 11.11 & 83.33 & 5.56 & 26.32 & 5.26 & 68.42 \\
\hline Taiwan & 92.86 & 2.38 & 4.76 & 23.53 & 76.47 & 0.00 & 27.27 & 9.09 & 63.64 \\
\hline Thailand & 93.18 & 3.41 & 3.41 & 9.09 & 86.36 & 4.55 & 18.18 & 0.00 & 81.82 \\
\hline Turkey & 94.12 & 4.41 & 1.47 & 7.69 & 76.92 & 15.38 & 15.79 & 0.00 & 84.21 \\
\hline Ukraine & 97.14 & 2.86 & 0.00 & 0.00 & 94.44 & 5.56 & 14.29 & 0.00 & 85.71 \\
\hline Venezuela & 94.44 & 3.70 & 1.85 & 12.50 & 81.25 & 6.25 & 16.67 & 16.67 & 66.67 \\
\hline
\end{tabular}

Note: Calculations follow the identification method discussed in Section 4. 
Table A8: Transitional Likelihoods, Debt Inflows

\begin{tabular}{|c|c|c|c|c|c|c|c|c|c|}
\hline Country & \begin{tabular}{|c|} 
Normal to \\
Normal
\end{tabular} & $\begin{array}{c}\text { Normal to } \\
\text { Surge }\end{array}$ & $\begin{array}{c}\text { Normal to } \\
\text { Stop }\end{array}$ & $\begin{array}{c}\text { Surge to } \\
\text { Normal }\end{array}$ & $\begin{array}{l}\text { Surge to } \\
\text { Surge }\end{array}$ & $\begin{array}{c}\text { Surge to } \\
\text { Stop }\end{array}$ & $\begin{array}{l}\text { Stop to } \\
\text { Normal }\end{array}$ & $\begin{array}{c}\text { Stop to } \\
\text { Surge }\end{array}$ & $\begin{array}{c}\text { Stop to } \\
\text { Stop }\end{array}$ \\
\hline \multicolumn{10}{|c|}{ Advanced Economies } \\
\hline Australia & 93.26 & 3.37 & 3.37 & 10.00 & 83.33 & 6.67 & 20.00 & 10.00 & 70.00 \\
\hline Austria & 93.20 & 2.91 & 3.88 & 27.27 & 72.73 & 0.00 & 16.00 & 0.00 & 84.00 \\
\hline Canada & 94.64 & 3.57 & 1.79 & 23.08 & 69.23 & 7.69 & 21.43 & 0.00 & 78.57 \\
\hline Denmark & 91.75 & 2.06 & 6.19 & 14.29 & 78.57 & 7.14 & 24.00 & 4.00 & 72.00 \\
\hline Finland & 91.92 & 4.04 & 4.04 & 23.53 & 70.59 & 5.88 & 20.00 & 5.00 & 75.00 \\
\hline France & 93.33 & 2.86 & 3.81 & 25.00 & 75.00 & 0.00 & 21.05 & 0.00 & 78.95 \\
\hline Germany & 87.50 & 6.82 & 5.68 & 29.17 & 70.83 & 0.00 & 18.52 & 0.00 & 81.48 \\
\hline Greece & 94.44 & 3.33 & 2.22 & 10.53 & 73.68 & 15.79 & 17.39 & 8.70 & 73.91 \\
\hline Iceland & 89.89 & 4.49 & 5.62 & 17.39 & 82.61 & 0.00 & 25.00 & 0.00 & 75.00 \\
\hline Ireland & 91.78 & 5.48 & 2.74 & 21.43 & 78.57 & 0.00 & 9.09 & 9.09 & 81.82 \\
\hline Italy & 92.23 & 4.85 & 2.91 & 29.41 & 70.59 & 0.00 & 15.79 & 0.00 & 84.21 \\
\hline Japan & 93.02 & 3.49 & 3.49 & 17.39 & 82.61 & 0.00 & 15.79 & 5.26 & 78.95 \\
\hline Netherlands & 95.37 & 2.78 & 1.85 & 18.18 & 72.73 & 9.09 & 15.00 & 0.00 & 85.00 \\
\hline New Zealand & 94.32 & 3.41 & 2.27 & 15.38 & 76.92 & 7.69 & 20.00 & 0.00 & 80.00 \\
\hline Norway & 89.41 & 4.71 & 5.88 & 18.52 & 81.48 & 0.00 & 16.67 & 4.17 & 79.17 \\
\hline Portugal & 90.32 & 4.30 & 5.38 & 18.18 & 77.27 & 4.55 & 23.81 & 4.76 & 71.43 \\
\hline Spain & 90.11 & 6.59 & 3.30 & 18.18 & 77.27 & 4.55 & 17.39 & 0.00 & 82.61 \\
\hline Sweden & 96.26 & 1.87 & 1.87 & 6.25 & 87.50 & 6.25 & 23.08 & 0.00 & 76.92 \\
\hline United Kingom & 94.17 & 2.91 & 2.91 & 19.05 & 76.19 & 4.76 & 20.00 & 6.67 & 73.33 \\
\hline United States & 93.07 & 4.95 & 1.98 & 18.75 & 68.75 & 12.50 & 18.18 & 0.00 & 81.82 \\
\hline \multicolumn{10}{|c|}{ Emerging Economies } \\
\hline Argentina & 95.05 & 0.00 & 4.95 & 12.50 & 87.50 & 0.00 & 17.39 & 4.35 & 78.26 \\
\hline Bangladesh & 92.73 & 2.73 & 4.55 & 33.33 & 66.67 & 0.00 & 38.46 & 0.00 & 61.54 \\
\hline Bolivia & 92.65 & 2.94 & 4.41 & 25.00 & 75.00 & 0.00 & 25.00 & 0.00 & 75.00 \\
\hline Brazil & 94.12 & 2.94 & 2.94 & 13.33 & 80.00 & 6.67 & 21.05 & 0.00 & 78.95 \\
\hline Chile & 97.40 & 2.60 & 0.00 & 14.29 & 71.43 & 14.29 & 25.00 & 0.00 & 75.00 \\
\hline Colombia & 91.11 & 4.44 & 4.44 & 33.33 & 66.67 & 0.00 & 17.65 & 0.00 & 82.35 \\
\hline Croatia & 91.84 & 4.08 & 4.08 & 22.22 & 77.78 & 0.00 & 50.00 & 0.00 & 50.00 \\
\hline Czech Republic & 93.62 & 4.26 & 2.13 & 11.11 & 77.78 & 11.11 & 25.00 & 0.00 & 75.00 \\
\hline Estonia & 95.92 & 2.04 & 2.04 & 16.67 & 66.67 & 16.67 & 15.38 & 0.00 & 84.62 \\
\hline Hungary & 95.00 & 0.00 & 5.00 & 20.00 & 80.00 & 0.00 & 16.67 & 8.33 & 75.00 \\
\hline India & 91.67 & 6.25 & 2.08 & 19.23 & 76.92 & 3.85 & 21.43 & 0.00 & 78.57 \\
\hline Indonesia & 92.31 & 4.40 & 3.30 & 40.00 & 60.00 & 0.00 & 27.27 & 0.00 & 72.73 \\
\hline Israel & 94.55 & 1.82 & 3.64 & 23.08 & 76.92 & 0.00 & 18.75 & 6.25 & 75.00 \\
\hline Jordan & 96.04 & 1.98 & 1.98 & 18.18 & 72.73 & 9.09 & 12.50 & 6.25 & 81.25 \\
\hline Korea & 95.05 & 1.98 & 2.97 & 20.00 & 80.00 & 0.00 & 12.50 & 6.25 & 81.25 \\
\hline Latvia & 90.24 & 7.32 & 2.44 & 18.75 & 81.25 & 0.00 & 28.57 & 0.00 & 71.43 \\
\hline Lithuania & 95.56 & 4.44 & 0.00 & 12.50 & 75.00 & 12.50 & 18.18 & 0.00 & 81.82 \\
\hline Mexico & 94.90 & 4.08 & 1.02 & 26.67 & 73.33 & 0.00 & 14.29 & 0.00 & 85.71 \\
\hline Moldova & 93.88 & 4.08 & 2.04 & 28.57 & 71.43 & 0.00 & 25.00 & 0.00 & 75.00 \\
\hline Pakistan & 91.67 & 4.17 & 4.17 & 18.18 & 81.82 & 0.00 & 21.43 & 7.14 & 71.43 \\
\hline Peru & 93.18 & 2.27 & 4.55 & 11.76 & 82.35 & 5.88 & 17.39 & 4.35 & 78.26 \\
\hline Philippines & 96.97 & 1.01 & 2.02 & 0.00 & 77.78 & 22.22 & 15.00 & 5.00 & 80.00 \\
\hline Poland & 94.20 & 2.90 & 2.90 & 14.29 & 78.57 & 7.14 & 15.38 & 7.69 & 76.92 \\
\hline Romania & 96.08 & 3.92 & 0.00 & 13.33 & 80.00 & 6.67 & 16.67 & 0.00 & 83.33 \\
\hline Russia & 95.45 & 0.00 & 4.55 & 0.00 & 80.00 & 20.00 & 9.09 & 9.09 & 81.82 \\
\hline Singapore & 92.65 & 4.41 & 2.94 & 18.18 & 72.73 & 9.09 & 23.08 & 0.00 & 76.92 \\
\hline Slovakia & 93.18 & 4.55 & 2.27 & 14.29 & 71.43 & 14.29 & 23.08 & 0.00 & 76.92 \\
\hline Slovenia & 91.84 & 6.12 & 2.04 & 21.43 & 78.57 & 0.00 & 20.00 & 0.00 & 80.00 \\
\hline SouthAfrica & 90.32 & 6.45 & 3.23 & 21.05 & 73.68 & 5.26 & 13.33 & 6.67 & 80.00 \\
\hline Sri Lanka & 92.94 & 4.71 & 2.35 & 15.38 & 76.92 & 7.69 & 17.65 & 5.88 & 76.47 \\
\hline Taiwan & 92.94 & 2.35 & 4.71 & 28.57 & 71.43 & 0.00 & 23.08 & 7.69 & 69.23 \\
\hline Thailand & 90.91 & 3.90 & 5.19 & 6.90 & 86.21 & 6.90 & 19.23 & 3.85 & 76.92 \\
\hline Turkey & 92.06 & 4.76 & 3.17 & 10.53 & 78.95 & 10.53 & 16.67 & 5.56 & 77.78 \\
\hline Ukraine & 92.86 & 4.76 & 2.38 & 16.67 & 83.33 & 0.00 & 16.67 & 0.00 & 83.33 \\
\hline Venezuela & 96.67 & 1.67 & 1.67 & 11.11 & 77.78 & 11.11 & 14.29 & 14.29 & 71.43 \\
\hline
\end{tabular}

Note: Calculations follow the identification method discussed in Section 4. 
Table A9: Transitional Likelihoods, Equity Inflows

\begin{tabular}{|c|c|c|c|c|c|c|c|c|c|}
\hline Country & $\begin{array}{c}\text { Normal to } \\
\text { Normal }\end{array}$ & $\begin{array}{c}\text { Normal to } \\
\text { Surge }\end{array}$ & $\begin{array}{c}\text { Normal to } \\
\text { Stop }\end{array}$ & $\begin{array}{c}\text { Surge to } \\
\text { Normal }\end{array}$ & $\begin{array}{l}\text { Surge to } \\
\text { Surge }\end{array}$ & $\begin{array}{l}\text { Surge to } \\
\text { Stop }\end{array}$ & $\begin{array}{l}\text { Stop to } \\
\text { Normal }\end{array}$ & $\begin{array}{c}\text { Stop to } \\
\text { Surge }\end{array}$ & $\begin{array}{c}\text { Stop to } \\
\text { Stop }\end{array}$ \\
\hline \multicolumn{10}{|c|}{ Advanced Economies } \\
\hline Australia & 93.14 & 3.92 & 2.94 & 20.00 & 75.00 & 5.00 & 17.65 & 5.88 & 76.47 \\
\hline Austria & 94.95 & 5.05 & 0.00 & 8.33 & 79.17 & 12.50 & 18.75 & 0.00 & 81.25 \\
\hline Canada & 96.08 & 2.94 & 0.98 & 7.14 & 71.43 & 21.43 & 17.39 & 0.00 & 82.61 \\
\hline Denmark & 94.95 & 4.04 & 1.01 & 8.33 & 83.33 & 8.33 & 23.08 & 0.00 & 76.92 \\
\hline Finland & 91.67 & 4.17 & 4.17 & 15.38 & 84.62 & 0.00 & 21.43 & 7.14 & 71.43 \\
\hline France & 90.43 & 4.26 & 5.32 & 18.18 & 81.82 & 0.00 & 25.00 & 0.00 & 75.00 \\
\hline Germany & 91.58 & 4.21 & 4.21 & 16.67 & 79.17 & 4.17 & 20.00 & 5.00 & 75.00 \\
\hline Greece & 94.62 & 3.23 & 2.15 & 14.29 & 85.71 & 0.00 & 11.11 & 5.56 & 83.33 \\
\hline Iceland & 92.22 & 4.44 & 3.33 & 13.79 & 86.21 & 0.00 & 23.08 & 0.00 & 76.92 \\
\hline Ireland & 89.23 & 4.62 & 6.15 & 13.79 & 86.21 & 0.00 & 22.22 & 5.56 & 72.22 \\
\hline Italy & 91.51 & 2.83 & 5.66 & 21.05 & 78.95 & 0.00 & 35.71 & 7.14 & 57.14 \\
\hline Japan & 92.47 & 4.30 & 3.23 & 17.65 & 76.47 & 5.88 & 22.22 & 0.00 & 77.78 \\
\hline Netherlands & 93.00 & 5.00 & 2.00 & 17.24 & 79.31 & 3.45 & 10.00 & 10.00 & 80.00 \\
\hline New Zealand & 94.25 & 2.30 & 3.45 & 16.67 & 75.00 & 8.33 & 17.65 & 5.88 & 76.47 \\
\hline Norway & 95.69 & 2.59 & 1.72 & 30.00 & 70.00 & 0.00 & 20.00 & 0.00 & 80.00 \\
\hline Portugal & 93.94 & 2.02 & 4.04 & 13.64 & 86.36 & 0.00 & 20.00 & 6.67 & 73.33 \\
\hline Spain & 92.63 & 5.26 & 2.11 & 15.38 & 80.77 & 3.85 & 20.00 & 0.00 & 80.00 \\
\hline Sweden & 93.94 & 4.04 & 2.02 & 10.00 & 80.00 & 10.00 & 23.53 & 0.00 & 76.47 \\
\hline United Kingom & 94.00 & 2.00 & 4.00 & 13.64 & 86.36 & 0.00 & 23.53 & 0.00 & 76.47 \\
\hline United States & 92.71 & 3.13 & 4.17 & 15.00 & 80.00 & 5.00 & 21.74 & 0.00 & 78.26 \\
\hline \multicolumn{10}{|c|}{ Emerging Economies } \\
\hline Argentina & 93.88 & 3.06 & 3.06 & 17.65 & 76.47 & 5.88 & 17.65 & 5.88 & 76.47 \\
\hline Bangladesh & 89.33 & 5.33 & 5.33 & 13.89 & 83.33 & 2.78 & 14.29 & 9.52 & 76.19 \\
\hline Bolivia & 89.66 & 6.90 & 3.45 & 18.75 & 75.00 & 6.25 & 20.00 & 0.00 & 80.00 \\
\hline Brazil & 93.62 & 3.19 & 3.19 & 6.67 & 80.00 & 13.33 & 22.22 & 0.00 & 77.78 \\
\hline Chile & 88.52 & 6.56 & 4.92 & 23.53 & 76.47 & 0.00 & 30.00 & 0.00 & 70.00 \\
\hline Colombia & 93.62 & 4.26 & 2.13 & 12.50 & 87.50 & 0.00 & 20.00 & 0.00 & 80.00 \\
\hline Croatia & 90.00 & 5.00 & 5.00 & 10.00 & 80.00 & 10.00 & 14.29 & 7.14 & 78.57 \\
\hline Czech Republic & 98.33 & 0.00 & 1.67 & $\ldots$ & $\ldots$ & $\ldots$ & 25.00 & 0.00 & 75.00 \\
\hline Estonia & 90.91 & 9.09 & 0.00 & 16.67 & 66.67 & 16.67 & 16.67 & 0.00 & 83.33 \\
\hline Hungary & 92.59 & 5.56 & 1.85 & 15.79 & 84.21 & 0.00 & 25.00 & 0.00 & 75.00 \\
\hline India & 97.14 & 2.86 & 0.00 & 7.69 & 88.46 & 3.85 & 20.00 & 0.00 & 80.00 \\
\hline Indonesia & 91.57 & 6.02 & 2.41 & 23.81 & 76.19 & 0.00 & 25.00 & 0.00 & 75.00 \\
\hline Israel & 91.11 & 5.56 & 3.33 & 13.33 & 80.00 & 6.67 & 21.05 & 5.26 & 73.68 \\
\hline Jordan & 97.03 & 2.97 & 0.00 & 7.14 & 78.57 & 14.29 & 23.08 & 0.00 & 76.92 \\
\hline Korea & 84.72 & 11.11 & 4.17 & 19.51 & 78.05 & 2.44 & 21.05 & 0.00 & 78.95 \\
\hline Latvia & 93.33 & 4.44 & 2.22 & 16.67 & 83.33 & 0.00 & 14.29 & 0.00 & 85.71 \\
\hline Lithuania & 93.18 & 4.55 & 2.27 & 22.22 & 66.67 & 11.11 & 18.18 & 0.00 & 81.82 \\
\hline Mexico & 93.75 & 3.75 & 2.50 & 10.00 & 86.67 & 3.33 & 20.00 & 10.00 & 70.00 \\
\hline Moldova & 93.18 & 4.55 & 2.27 & 18.18 & 81.82 & 0.00 & 20.00 & 0.00 & 80.00 \\
\hline Pakistan & 92.77 & 6.02 & 1.20 & 5.71 & 88.57 & 5.71 & 21.43 & 0.00 & 78.57 \\
\hline Peru & 94.38 & 2.25 & 3.37 & 16.67 & 83.33 & 0.00 & 14.29 & 4.76 & 80.95 \\
\hline Philippines & 94.19 & 5.81 & 0.00 & 7.41 & 81.48 & 11.11 & 20.00 & 0.00 & 80.00 \\
\hline Poland & 87.93 & 8.62 & 3.45 & 13.79 & 86.21 & 0.00 & 22.22 & 0.00 & 77.78 \\
\hline Romania & 88.89 & 6.67 & 4.44 & 15.38 & 76.92 & 7.69 & 21.43 & 0.00 & 78.57 \\
\hline Russia & 82.86 & 14.29 & 2.86 & 25.00 & 68.75 & 6.25 & 11.11 & 0.00 & 88.89 \\
\hline Singapore & 94.37 & 1.41 & 4.23 & 16.67 & 83.33 & 0.00 & 11.11 & 11.11 & 77.78 \\
\hline Slovakia & 91.11 & 6.67 & 2.22 & 20.00 & 70.00 & 10.00 & 22.22 & 0.00 & 77.78 \\
\hline Slovenia & 95.92 & 2.04 & 2.04 & 0.00 & 88.89 & 11.11 & 20.00 & 0.00 & 80.00 \\
\hline SouthAfrica & 92.54 & 4.48 & 2.99 & 17.39 & 82.61 & 0.00 & 16.67 & 16.67 & 66.67 \\
\hline Sri Lanka & 90.91 & 5.68 & 3.41 & 19.23 & 80.77 & 0.00 & 21.43 & 0.00 & 78.57 \\
\hline Taiwan & 90.32 & 6.45 & 3.23 & 15.63 & 78.13 & 6.25 & 5.56 & 16.67 & 77.78 \\
\hline Thailand & 92.13 & 5.62 & 2.25 & 13.33 & 83.33 & 3.33 & 23.08 & 0.00 & 76.92 \\
\hline Turkey & 89.29 & 3.57 & 7.14 & 9.52 & 85.71 & 4.76 & 17.39 & 4.35 & 78.26 \\
\hline Ukraine & 93.75 & 4.17 & 2.08 & 22.22 & 77.78 & 0.00 & 0.00 & 0.00 & 100.00 \\
\hline Venezuela & 96.61 & 1.69 & 1.69 & 0.00 & 87.50 & 12.50 & 22.22 & 0.00 & 77.78 \\
\hline
\end{tabular}

Notes: ... = data is unavailable. Calculations follow the identification method discussed in Section 4. 
Table A10: State-Dependence Variables, Total Gross Inflows

\begin{tabular}{|c|c|c|c|c|c|c|}
\hline \multirow{2}{*}{ Country } & \multirow{2}{*}{$\begin{array}{c}\text { Duration } \\
\text { Normal }\end{array}$} & \multirow{2}{*}{$\begin{array}{c}\text { Duration } \\
\text { Surge }\end{array}$} & \multirow{2}{*}{$\begin{array}{c}\text { Duration } \\
\text { Stop }\end{array}$} & \multicolumn{3}{|c|}{ Occurrence Occurrence Occurrence } \\
\hline & & & & Nornal & Surge & Stop \\
\hline \multicolumn{7}{|c|}{ Advanced Economies } \\
\hline Australia & 59.29 & 23.57 & 17.14 & 42.86 & 38.10 & 19.05 \\
\hline Austria & 79.29 & 13.57 & 7.14 & 53.85 & 30.77 & 15.38 \\
\hline Canada & 77.14 & 11.43 & 11.43 & 50.00 & 25.00 & 25.00 \\
\hline Denmark & 75.91 & 5.11 & 18.98 & 47.06 & 11.76 & 35.29 \\
\hline Finland & 70.80 & 14.60 & 14.60 & 50.00 & 26.92 & 19.23 \\
\hline France & 72.99 & 11.68 & 15.33 & 47.06 & 23.53 & 23.53 \\
\hline Germany & 65.00 & 16.43 & 18.57 & 45.00 & 30.00 & 25.00 \\
\hline Greece & 60.90 & 19.55 & 19.55 & 33.33 & 33.33 & 28.57 \\
\hline Iceland & 66.17 & 19.55 & 14.29 & 50.00 & 22.22 & 22.22 \\
\hline Ireland & 58.41 & 32.74 & 8.85 & 42.11 & 42.11 & 10.53 \\
\hline Italy & 70.00 & 11.43 & 18.57 & 50.00 & 25.00 & 25.00 \\
\hline Japan & 70.54 & 13.95 & 15.50 & 46.15 & 23.08 & 23.08 \\
\hline Netherlands & 76.43 & 7.14 & 16.43 & 53.85 & 15.38 & 30.77 \\
\hline New Zealand & 73.50 & 11.11 & 15.38 & 46.67 & 20.00 & 26.67 \\
\hline Norway & 64.96 & 17.52 & 17.52 & 48.15 & 25.93 & 22.22 \\
\hline Portugal & 64.96 & 20.44 & 14.60 & 45.45 & 27.27 & 22.73 \\
\hline Spain & 69.34 & 13.87 & 16.79 & 41.18 & 29.41 & 23.53 \\
\hline Sweden & 72.99 & 14.60 & 12.41 & 46.67 & 20.00 & 26.67 \\
\hline United Kingom & 72.14 & 15.71 & 12.14 & 40.00 & 33.33 & 26.67 \\
\hline United States & 65.00 & 15.71 & 19.29 & 45.00 & 30.00 & 25.00 \\
\hline \multicolumn{7}{|c|}{ Emerging Economies } \\
\hline Argentina & 78.20 & 6.77 & 15.04 & 45.45 & 9.09 & 36.36 \\
\hline Bangladesh & 78.95 & 12.78 & 8.27 & 47.37 & 31.58 & 15.79 \\
\hline Bolivia & 64.71 & 17.65 & 17.65 & 36.36 & 27.27 & 27.27 \\
\hline Brazil & 73.72 & 13.87 & 12.41 & 41.18 & 29.41 & 23.53 \\
\hline Chile & 77.53 & 8.99 & 13.48 & 45.45 & 18.18 & 27.27 \\
\hline Colombia & 79.71 & 10.14 & 10.14 & 50.00 & 25.00 & 12.50 \\
\hline Croatia & 75.38 & 7.69 & 16.92 & 44.44 & 11.11 & 33.33 \\
\hline Czech Republic & 89.23 & 4.62 & 6.15 & 50.00 & 16.67 & 16.67 \\
\hline Estonia & 59.42 & 21.74 & 18.84 & 33.33 & 33.33 & 22.22 \\
\hline Hungary & 70.51 & 19.23 & 10.26 & 46.15 & 23.08 & 23.08 \\
\hline India & 64.23 & 25.55 & 10.22 & 47.62 & 33.33 & 14.29 \\
\hline Indonesia & 76.11 & 14.16 & 9.73 & 47.06 & 23.53 & 23.53 \\
\hline Israel & 72.14 & 13.57 & 14.29 & 43.75 & 25.00 & 31.25 \\
\hline Jordan & 82.17 & 10.08 & 7.75 & 45.45 & 27.27 & 18.18 \\
\hline Korea & 71.43 & 15.04 & 13.53 & 42.86 & 28.57 & 21.43 \\
\hline Latvia & 66.15 & 21.54 & 12.31 & 44.44 & 22.22 & 22.22 \\
\hline Lithuania & 60.00 & 18.46 & 21.54 & 45.45 & 18.18 & 27.27 \\
\hline Mexico & 80.99 & 10.74 & 8.26 & 44.44 & 22.22 & 22.22 \\
\hline Moldova & 77.05 & 13.11 & 9.84 & 40.00 & 20.00 & 20.00 \\
\hline Pakistan & 60.15 & 26.32 & 13.53 & 47.37 & 31.58 & 15.79 \\
\hline Peru & 71.32 & 14.73 & 13.95 & 46.67 & 20.00 & 26.67 \\
\hline Philippines & 72.09 & 10.85 & 17.05 & 37.50 & 25.00 & 31.25 \\
\hline Poland & 77.32 & 11.34 & 11.34 & 45.45 & 18.18 & 27.27 \\
\hline Romania & 64.38 & 26.03 & 9.59 & 45.45 & 36.36 & 9.09 \\
\hline Russia & 78.69 & 8.20 & 13.11 & 42.86 & 14.29 & 28.57 \\
\hline Singapore & 75.27 & 12.90 & 11.83 & 40.00 & 30.00 & 20.00 \\
\hline Slovakia & 67.69 & 12.31 & 20.00 & 45.45 & 18.18 & 27.27 \\
\hline Slovenia & 72.46 & 13.04 & 14.49 & 44.44 & 22.22 & 22.22 \\
\hline SouthAfrica & 69.07 & 21.65 & 9.28 & 45.45 & 27.27 & 18.18 \\
\hline Sri Lanka & 71.32 & 13.95 & 14.73 & 41.18 & 17.65 & 35.29 \\
\hline Taiwan & 75.22 & 15.04 & 9.73 & 43.75 & 25.00 & 25.00 \\
\hline Thailand & 66.92 & 16.54 & 16.54 & 46.67 & 20.00 & 26.67 \\
\hline Turkey & 68.32 & 12.87 & 18.81 & 41.67 & 25.00 & 25.00 \\
\hline Ukraine & 59.02 & 29.51 & 11.48 & 40.00 & 20.00 & 20.00 \\
\hline Venezuela & 71.43 & 20.78 & 7.79 & 40.00 & 30.00 & 20.00 \\
\hline
\end{tabular}

Note: Calculations follow the definition of "duration" and "occurrence" discussed in Section 4. 
Table A11: State-Dependence Variables, Debt Inflows

\begin{tabular}{|c|c|c|c|c|c|c|}
\hline Country & $\begin{array}{l}\text { Duration } \\
\text { Normal }\end{array}$ & $\begin{array}{l}\text { Duration } \\
\text { Surge }\end{array}$ & $\begin{array}{c}\text { Duration } \\
\text { Stop }\end{array}$ & $\begin{array}{c}\text { Occurrence } \\
\text { Nornal }\end{array}$ & $\begin{array}{c}\text { Occurrence } \\
\text { Surge }\end{array}$ & $\begin{array}{c}\text { Occurrence } \\
\text { Stop }\end{array}$ \\
\hline \multicolumn{7}{|c|}{ Advanced Economies } \\
\hline Australia & 64.29 & 21.43 & 14.29 & 38.89 & 27.78 & 33.33 \\
\hline Austria & 74.29 & 7.86 & 17.86 & 53.33 & 20.00 & 26.67 \\
\hline Canada & 80.71 & 9.29 & 10.00 & 50.00 & 28.57 & 21.43 \\
\hline Denmark & 71.53 & 10.22 & 18.25 & 45.00 & 15.00 & 35.00 \\
\hline Finland & 72.99 & 12.41 & 14.60 & 45.00 & 25.00 & 25.00 \\
\hline France & 77.37 & 8.76 & 13.87 & 50.00 & 18.75 & 25.00 \\
\hline Germany & 63.57 & 17.14 & 19.29 & 50.00 & 29.17 & 20.83 \\
\hline Greece & 68.42 & 14.29 & 17.29 & 33.33 & 27.78 & 33.33 \\
\hline Iceland & 67.67 & 17.29 & 15.04 & 50.00 & 20.00 & 25.00 \\
\hline Ireland & 65.49 & 24.78 & 9.73 & 43.75 & 37.50 & 12.50 \\
\hline Italy & 74.29 & 12.14 & 13.57 & 52.94 & 29.41 & 17.65 \\
\hline Japan & 67.44 & 17.83 & 14.73 & 43.75 & 25.00 & 25.00 \\
\hline Netherlands & 77.86 & 7.86 & 14.29 & 50.00 & 25.00 & 25.00 \\
\hline New Zealand & 76.07 & 11.11 & 12.82 & 46.15 & 23.08 & 23.08 \\
\hline Norway & 62.77 & 19.71 & 17.52 & 47.62 & 23.81 & 23.81 \\
\hline Portugal & 68.61 & 16.06 & 15.33 & 45.45 & 22.73 & 27.27 \\
\hline Spain & 66.42 & 16.79 & 16.79 & 45.00 & 30.00 & 20.00 \\
\hline Sweden & 78.83 & 11.68 & 9.49 & 45.45 & 18.18 & 27.27 \\
\hline United Kingom & 74.29 & 15.00 & 10.71 & 43.75 & 31.25 & 25.00 \\
\hline United States & 72.86 & 11.43 & 15.71 & 47.06 & 29.41 & 23.53 \\
\hline \multicolumn{7}{|c|}{ Emerging Economies } \\
\hline Argentina & 76.69 & 6.02 & 17.29 & 46.15 & 7.69 & 38.46 \\
\hline Bangladesh & 83.46 & 6.77 & 9.77 & 50.00 & 16.67 & 27.78 \\
\hline Bolivia & 80.00 & 9.41 & 10.59 & 45.45 & 18.18 & 27.27 \\
\hline Brazil & 75.18 & 10.95 & 13.87 & 46.67 & 20.00 & 26.67 \\
\hline Chile & 87.64 & 7.87 & 4.49 & 42.86 & 28.57 & 14.29 \\
\hline Colombia & 66.67 & 8.70 & 24.64 & 45.45 & 18.18 & 27.27 \\
\hline Croatia & 76.92 & 13.85 & 9.23 & 45.45 & 18.18 & 27.27 \\
\hline Czech Republic & 73.85 & 13.85 & 12.31 & 44.44 & 22.22 & 22.22 \\
\hline Estonia & 72.46 & 8.70 & 18.84 & 37.50 & 25.00 & 25.00 \\
\hline Hungary & 78.21 & 6.41 & 15.38 & 44.44 & 11.11 & 33.33 \\
\hline India & 70.80 & 18.98 & 10.22 & 47.37 & 31.58 & 15.79 \\
\hline Indonesia & 81.42 & 8.85 & 9.73 & 50.00 & 25.00 & 18.75 \\
\hline Israel & 79.29 & 9.29 & 11.43 & 50.00 & 21.43 & 28.57 \\
\hline Jordan & 79.07 & 8.53 & 12.40 & 41.67 & 25.00 & 25.00 \\
\hline Korea & 76.69 & 11.28 & 12.03 & 46.15 & 23.08 & 23.08 \\
\hline Latvia & 64.62 & 24.62 & 10.77 & 45.45 & 27.27 & 18.18 \\
\hline Lithuania & 70.77 & 12.31 & 16.92 & 37.50 & 25.00 & 25.00 \\
\hline Mexico & 81.82 & 12.40 & 5.79 & 50.00 & 33.33 & 8.33 \\
\hline Moldova & 81.97 & 11.48 & 6.56 & 50.00 & 25.00 & 12.50 \\
\hline Pakistan & 72.18 & 17.29 & 10.53 & 44.44 & 27.78 & 22.22 \\
\hline Peru & 68.99 & 13.18 & 17.83 & 43.75 & 18.75 & 31.25 \\
\hline Philippines & 77.52 & 6.98 & 15.50 & 36.36 & 18.18 & 36.36 \\
\hline Poland & 72.16 & 14.43 & 13.40 & 41.67 & 25.00 & 25.00 \\
\hline Romania & 71.23 & 20.55 & 8.22 & 37.50 & 37.50 & 12.50 \\
\hline Russia & 72.13 & 8.20 & 19.67 & 28.57 & 14.29 & 42.86 \\
\hline Singapore & 74.19 & 11.83 & 13.98 & 46.15 & 23.08 & 23.08 \\
\hline Slovakia & 69.23 & 10.77 & 20.00 & 40.00 & 20.00 & 30.00 \\
\hline Slovenia & 72.46 & 20.29 & 7.25 & 50.00 & 30.00 & 10.00 \\
\hline SouthAfrica & 64.95 & 19.59 & 15.46 & 43.75 & 31.25 & 18.75 \\
\hline Sri Lanka & 66.67 & 20.16 & 13.18 & 38.89 & 33.33 & 22.22 \\
\hline Taiwan & 76.11 & 12.39 & 11.50 & 43.75 & 25.00 & 25.00 \\
\hline Thailand & 58.65 & 21.80 & 19.55 & 42.11 & 21.05 & 31.58 \\
\hline Turkey & 63.37 & 18.81 & 17.82 & 40.00 & 26.67 & 26.67 \\
\hline Ukraine & 70.49 & 19.67 & 9.84 & 50.00 & 25.00 & 12.50 \\
\hline Venezuela & 79.22 & 11.69 & 9.09 & 37.50 & 25.00 & 25.00 \\
\hline
\end{tabular}

Note: Calculations follow definition of "duration" and "occurrence" discussed in Section 4. 
Table A12: State-Dependence Variables, Equity Inflows

\begin{tabular}{|c|c|c|c|c|c|c|}
\hline \multirow{2}{*}{ Country } & \multirow{2}{*}{$\begin{array}{c}\text { Duration } \\
\text { Normal }\end{array}$} & \multirow{2}{*}{$\begin{array}{c}\text { Duration } \\
\text { Surge }\end{array}$} & \multirow{2}{*}{$\begin{array}{c}\text { Duration } \\
\text { Stop }\end{array}$} & \multicolumn{3}{|c|}{ Occurrence Occurrence Occurrence } \\
\hline & & & & Nornal & Surge & Stop \\
\hline \multicolumn{7}{|c|}{ Advanced Economies } \\
\hline Australia & 73.57 & 14.29 & 12.14 & 47.06 & 29.41 & 23.53 \\
\hline Austria & 71.43 & 17.14 & 11.43 & 42.86 & 35.71 & 21.43 \\
\hline Canada & 73.57 & 10.00 & 16.43 & 38.46 & 30.77 & 30.77 \\
\hline Denmark & 72.99 & 17.52 & 9.49 & 42.86 & 28.57 & 21.43 \\
\hline Finland & 70.07 & 19.71 & 10.22 & 44.44 & 27.78 & 22.22 \\
\hline France & 69.34 & 16.06 & 14.60 & 50.00 & 20.00 & 25.00 \\
\hline Germany & 68.57 & 17.14 & 14.29 & 47.37 & 26.32 & 26.32 \\
\hline Greece & 69.92 & 16.54 & 13.53 & 38.46 & 30.77 & 23.08 \\
\hline Iceland & 68.42 & 21.80 & 9.77 & 50.00 & 25.00 & 18.75 \\
\hline Ireland & 58.41 & 25.66 & 15.93 & 44.44 & 22.22 & 27.78 \\
\hline Italy & 76.43 & 13.57 & 10.00 & 50.00 & 20.00 & 30.00 \\
\hline Japan & 72.87 & 13.18 & 13.95 & 47.06 & 23.53 & 23.53 \\
\hline Netherlands & 71.43 & 20.71 & 7.86 & 43.75 & 37.50 & 18.75 \\
\hline New Zealand & 75.21 & 10.26 & 14.53 & 42.86 & 21.43 & 28.57 \\
\hline Norway & 85.40 & 7.30 & 7.30 & 50.00 & 25.00 & 16.67 \\
\hline Portugal & 72.99 & 16.06 & 10.95 & 46.67 & 20.00 & 26.67 \\
\hline Spain & 70.07 & 18.98 & 10.95 & 47.06 & 29.41 & 17.65 \\
\hline Sweden & 72.99 & 14.60 & 12.41 & 43.75 & 25.00 & 25.00 \\
\hline United Kingom & 72.14 & 15.71 & 12.14 & 50.00 & 21.43 & 28.57 \\
\hline United States & 69.29 & 14.29 & 16.43 & 47.06 & 23.53 & 29.41 \\
\hline \multicolumn{7}{|c|}{ Emerging Economies } \\
\hline Argentina & 74.44 & 12.78 & 12.78 & 43.75 & 25.00 & 25.00 \\
\hline Bangladesh & 57.14 & 27.07 & 15.79 & 42.86 & 28.57 & 23.81 \\
\hline Bolivia & 68.24 & 18.82 & 12.94 & 42.86 & 28.57 & 21.43 \\
\hline Brazil & 69.34 & 10.95 & 19.71 & 41.18 & 17.65 & 35.29 \\
\hline Chile & 69.66 & 19.10 & 11.24 & 50.00 & 25.00 & 18.75 \\
\hline Colombia & 69.57 & 23.19 & 7.25 & 50.00 & 25.00 & 12.50 \\
\hline Croatia & 61.54 & 16.92 & 21.54 & 36.36 & 27.27 & 27.27 \\
\hline Czech Republic & 93.85 & $\cdots$ & 6.15 & 50.00 & $\cdots$ & 25.00 \\
\hline Estonia & 65.22 & 17.39 & 17.39 & 41.67 & 33.33 & 16.67 \\
\hline Hungary & 70.51 & 24.36 & 5.13 & 50.00 & 30.00 & 10.00 \\
\hline India & 77.37 & 18.98 & 3.65 & 44.44 & 33.33 & 11.11 \\
\hline Indonesia & 74.34 & 18.58 & 7.08 & 50.00 & 31.25 & 12.50 \\
\hline Israel & 65.00 & 21.43 & 13.57 & 45.00 & 30.00 & 25.00 \\
\hline Jordan & 79.07 & 10.85 & 10.08 & 36.36 & 27.27 & 27.27 \\
\hline Korea & 54.89 & 30.83 & 14.29 & 46.15 & 34.62 & 15.38 \\
\hline Latvia & 70.77 & 18.46 & 10.77 & 50.00 & 25.00 & 12.50 \\
\hline Lithuania & 69.23 & 13.85 & 16.92 & 40.00 & 30.00 & 20.00 \\
\hline Mexico & 66.94 & 24.79 & 8.26 & 42.86 & 28.57 & 21.43 \\
\hline Moldova & 73.77 & 18.03 & 8.20 & 50.00 & 25.00 & 12.50 \\
\hline Pakistan & 62.41 & 27.07 & 10.53 & 40.00 & 33.33 & 20.00 \\
\hline Peru & 69.77 & 13.95 & 16.28 & 42.86 & 21.43 & 28.57 \\
\hline Philippines & 67.44 & 20.93 & 11.63 & 40.00 & 33.33 & 20.00 \\
\hline Poland & 59.79 & 30.93 & 9.28 & 46.67 & 33.33 & 13.33 \\
\hline Romania & 63.01 & 17.81 & 19.18 & 46.15 & 23.08 & 23.08 \\
\hline Russia & 57.38 & 26.23 & 16.39 & 42.86 & 35.71 & 14.29 \\
\hline Singapore & 76.34 & 12.90 & 10.75 & 40.00 & 20.00 & 30.00 \\
\hline Slovakia & 70.77 & 15.38 & 13.85 & 45.45 & 27.27 & 18.18 \\
\hline Slovenia & 72.46 & 13.04 & 14.49 & 42.86 & 14.29 & 28.57 \\
\hline SouthAfrica & 70.10 & 23.71 & 6.19 & 46.15 & 30.77 & 15.38 \\
\hline Sri Lanka & 68.99 & 20.16 & 10.85 & 50.00 & 27.78 & 16.67 \\
\hline Taiwan & 55.75 & 28.32 & 15.93 & 36.84 & 36.84 & 21.05 \\
\hline Thailand & 67.67 & 22.56 & 9.77 & 47.06 & 29.41 & 17.65 \\
\hline Turkey & 56.44 & 20.79 & 22.77 & 43.75 & 18.75 & 31.25 \\
\hline Ukraine & 78.69 & 14.75 & 6.56 & 42.86 & 28.57 & 14.29 \\
\hline Venezuela & 77.92 & 10.39 & 11.69 & 42.86 & 14.29 & 28.57 \\
\hline
\end{tabular}

Note: ... = data is unavailable. Calculations follow definition of "duration" and "occurrence" discussed in Section 4. 
Appendix 5: Dataset on Domestic Factors

Table A13: Domestic Factors Variables, Explanations and Sources

\begin{tabular}{|c|c|c|}
\hline Variable & Data & Source \\
\hline Output Volatility & $\begin{array}{c}\text { Standard deviation of annual } \\
\text { GDP growth rate }\end{array}$ & $\begin{array}{l}\text { World Economic Outlook } \\
\text { Database April 2016, } \\
\text { International Monetary Fund }\end{array}$ \\
\hline Per Capita Income & $\begin{array}{l}\text { Natural log value (multiplied by } \\
\text { 10) of average annual real per } \\
\text { capita income in constant } \\
\text { US\$2010 prices }\end{array}$ & $\begin{array}{c}\text { World Development Indicators, } \\
\text { World Bank }\end{array}$ \\
\hline Domestic Credit & $\begin{array}{l}\text { Average annual domestic credit } \\
\text { to private sector by banks as } \\
\text { percent of nominal GDP }\end{array}$ & $\begin{array}{c}\text { World Development Indicators, } \\
\text { World Bank }\end{array}$ \\
\hline Market Capitalization & $\begin{array}{l}\text { Average annual market } \\
\text { capitalization of listed companies } \\
\text { as percent of nominal GDP }\end{array}$ & $\begin{array}{l}\text { World Development Indicators, } \\
\text { World Bank; World Federation } \\
\text { of Exchanges, and national } \\
\text { sources accessed through CEIC. }\end{array}$ \\
\hline Trade Openness & $\begin{array}{l}\text { Merchandise trade as ratio of } \\
\text { nominal GDP is the annual } \\
\text { average of the sum of } \\
\text { merchandise exports and } \\
\text { imports divided by nominal GDP } \\
\text { in percent }\end{array}$ & $\begin{array}{c}\text { World Development Indicators, } \\
\text { World Bank. Data for Taiwan is } \\
\text { sourced from the National } \\
\text { Statistics Office. }\end{array}$ \\
\hline Financial Openness & $\begin{array}{c}\text { De facto financial openness } \\
\text { measure using annual average } \\
\text { values of the sum of total foreign } \\
\text { assets and liabilities as percent of } \\
\text { nominal GDP. }\end{array}$ & $\begin{array}{c}\text { External Wealth of Nations } \\
\text { (Lane and Milesi-Ferretti, 2007) }\end{array}$ \\
\hline Capital Openness & $\begin{array}{c}\text { De jure capital openness } \\
\text { measure is an average annual } \\
\text { normalized index where a higher } \\
\text { value pertains to less capital } \\
\text { account restrictions with the rest } \\
\text { of the world. Values are } \\
\text { multiplies by } 100\end{array}$ & Chinn and Ito (2006) \\
\hline Net Foreign Assets & $\begin{array}{c}\text { Average annual values of total } \\
\text { foreign assets minus total foreign } \\
\text { liabilities as percent of nominal } \\
\text { GDP }\end{array}$ & $\begin{array}{c}\text { External Wealth of Nations } \\
\text { (Lane and Milesi-Ferretti, 2007) }\end{array}$ \\
\hline Foreign Reserves & $\begin{array}{c}\text { Average annual values of foreign } \\
\text { currency reserves as percent of } \\
\text { nominal GDP }\end{array}$ & $\begin{array}{c}\text { External Wealth of Nations } \\
\text { (Lane and Milesi-Ferretti, 2007) }\end{array}$ \\
\hline Foreign Debt Liabilities & $\begin{array}{c}\text { Average annual values of foreign } \\
\text { debt liabilities as percent of } \\
\text { nominal GDP }\end{array}$ & $\begin{array}{c}\text { External Wealth of Nations } \\
\text { (Lane and Milesi-Ferretti, 2007) }\end{array}$ \\
\hline
\end{tabular}

Notes: Average annual values covers from 1980 to 2014 . However, in cases where data are unavailable, the average values are computed using the earliest year with available data. 


\section{References:}

Fernandez-Arias, E. 1996. The New Wave of Private Capital Inflows: Push or Pull? Journal of Development Economics. 48: 389-418.

Ballen, J. and R. Freeman. 1986. The Black Youth Employment Crisis. In Handbook in Labour Economics edited by R. Freeman and H. Holzer. University of Chicago Press.

Blau, D. 1998. Labour Force Dynamics of Older Married Couples. Journal of Labour Economics, 3(3): 595-629.

Bluedorn, J. C., R. Duttagupta, J. Guajardo, and P. Topalova. 2013. Capital Flows are Frickle: Anytime, Anywhere. IMF Working Paper No. 8/22.

Bradley, S., R. Crouchley, and R. Oskrochi. 2003. Social Exclusion and Labour Market Transitions: A Multi-State Multi-Spell Analysis Using the BHPS. Labour Economics, 10: 659-679.

Caballero, J. 2014. Do Surges in International Capital Inflows Influence the Likelihood of Banking Crises? The Economic Journal, doi:10.1111/ecoj.12172.

Calderon, C. and M. Kubota. 2013. Sudden Stops: Are Global and Local Investors Alike? Journal of International Economics, 89 (1): 122-142.

Calvo, G. 1998. Capital Flows and Capital-Market Crises: The Simple Economics of Sudden Stops. Journal of Applied Economics, 1: 35-54.

Calvo, G., L. Leiderman, and C. Reinhart. 1993. Capital Inflows and Real Exchange Rate Appreciation in Latin America: The Role of External Factors. IMF Staff Papers, 40(1): 108-151.

Calvo, G., L. Leiderman, and C. Reinhart. 1996. Inflows of Capital to Developing Countries in 1990s. Journal of Economic Perspectives, 10(2): 123-139.

Calvo, G., A. Izquierdo, and L.-F. Mejia. 2008. Systemic Sudden Stops: The Relevance of BalanceSheet Effects and Financial Integration. NBER Working Paper Series 14026.

Calvo, G., A. Izquierdo, and E. Talvi. 2006. Sudden Stops and Phoenix Miracles in Emerging Markets. American Economic Review, 96(2): 405-410.

Catão, L. and G. M. Milesi-Ferretti. 2014. External Liabilities and Crises. Journal of International Economics, 94 (1): 18-32.

Cavallo, E. and J. Frankel. 2008. Does Openness to Trade Make Countries More Vulnerable to Sudden Stops, or Less? Using Gravity to Establish Causality. Journal of International Money and Finance, 27: 1430-1452.

Chinn, M. and H. Ito. 2006. What Matters for Financial Development? Capital Controls, Institutions, and Interactions. Journal of Development Economics, 81(1): 163-192.

Chuhan, P., S. Claessens, and N. Mamingi. 1998. Equity and Bond Flows to Latin America and Asia: The Role of Global and Country Factors. Journal of Development Economics, 55: 439-463.

Crystallin M., L. Efremidze, S. Kim, W. Nugroho, O. Sula, and T. Willett. 2015. How Common Are Capital Flows Surges? How They Are Measured Matters A Lot. Open Economics Review, 26: 663-682.

Diebold, F. and G. Rudebusch. 1990. A Nonparametric Investigation of Duration Dependence in the American Business Cycle. Journal of Political Economy, 98(3): 596-616.

Faucette J., A. Rothenberg, and F. Warnock. 2005. Outflows-Induced Sudden Stops. The Journal of Policy Reform, 8(2): 119-129.

Filardo, A. 1994. Business-Cycle Phases and Their Transitional Dynamics. Journal of Business and Economics Statistics, 12(3): 299-308.

Filardo, A. and S. Gordon. 1998. Business Cycle Durations. Journal of Econometrics, 85: 99-123.

Forbes, K. and F. Warnock. 2012a. Capital Flow Waves, Surges, Stops, Flights and Retrenchment. Journal of International Economics, 88 (2): 235-251.

Forbes, K. and F. Warnock. 2012b. Debt- and Equity-Led Capital Flows Episodes. NBER Working Paper Series No. 18329.

Fratzscher, M. 2012. Capital Flows, Push versus Pull Factors and the Global Financial Crisis. Journal of International Economics, 88(2): 341-365. 
Ghosh, A., J. Kim, M. Qureshi, and J. Zalduendo. 2014. Surges. Journal of International Economics, 92(2): 266-285.

Hamilton, J. 1989. A New Approach to the Economic Analysis of Nonstationary Time Series and the Business Cycle. Econometrica, 57(2): 357-384.

Heckman, J. and G. Borjas. 1980. Does Unemployment Cause Future Unemployment? Definitions, Questions and Answers from a Continuous Time Model of Heterogeneity and State Dependence. Economica, 47(187): 247-283.

Kaminsky, G., C. Reinhart, and C. Vegh. 2005. When It Rains, It Pours: Procyclical Capital Flows and Macroeconomic Policies. NBER Macroeconomics Annual.

Koepke, R. 2015. What Drives Capital Flows to Emerging Markets? A Survey of Empirical Literature. Institute for International Financial Working Paper.

Lane, P. R. and G. M. Milesi-Ferretti. 2002. Long Term Capital Movements. NBER Macroeconomics Annual 16.

Lane, P. R. and G. M. Milesi-Ferretti. 2007. The External Wealth of Nations Mark II: Revised and Extended Estimates of Foreign Assets and Liabilities, 1970-2004. Journal of International Economics, 73(2): 223-250.

Levchenko, A. and P. Mauro. 2007. Do Some Forms of Financial Flows Help Protect Against "Sudden Stops"? The World Bank Economic Review, 21(3): 389-411.

Lynch, L. 1989. The Youth Labour Market in the Eighties: Determinants of Re-employment Probabilities for Young Men and Women. Review of Economics and Statistics, 71(1): 37-45.

Magud, N., C. Reinhart, and E. Vesperoni. 2014. Capital Inflows, Exchange Rate Flexibility, and Credit Booms. Review of Development Economics, 18(3): 415-430.

Martinez-Granado, M. 2002. Self-Employment and Labour Market Transitions: A Multiple State Model. CEPR Discussion Paper No. 3661.

Milesi-Ferretti, G.-M. and C. Tille. 2011. The Great Retrenchment: International Capital Flows during the Global Financial Crisis. Economic Policy, 26(66): 285-342.

Ostry, J., A. Ghosh, K. Habermeier, M. Chamon, M. Qureshi, and D. Reinhart. 2010. Capital Inflows: The Role of Controls. IMF Staff Position Note SPN/10/14.

Park, C.-Y. and R. Mercado. 2014. Equity Home Bias, Financial Integration, and Regulatory Reforms: Implications for Emerging Asia. In Global Shock, Risks, and Asian Financial Reform. Edited by I. Azis and H. S. Shin. Edward Elgar and Asian Development Bank.

Reinhart, C. and V. Reinhart. 2009. Capital Flow Bonanzas: An Encompassing View of the Past and Present. NBER International Seminar on Macroeconomics 2008.

Rothenberg, A. and F. Warnock. 2011. Sudden Flight and True Sudden Stops. Review of International Economics, 19(3): 509-524.

Sula, O. 2010. Surges and Sudden Stops of Capital Flows to Emerging Markets. Open Economics Review, 21:589-605. 